\title{
Hydrology, Sedimentology, and Biology of Ellison Park Wetland at the Mouth of Irondequoit Creek near Rochester, New York
}

By WILLIAM F. COON

U.S. GEOLOGICAL SURVEY

Water-Resources Investigations Report 96-4269

Prepared in cooperation with the MONROE COUNTY DEPARTMENT OF HEALTH

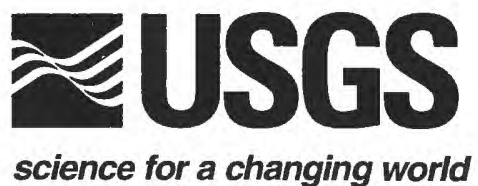




\title{
U.S. DEPARTMENT OF THE INTERIOR BRUCE BABBITT, Secretary
}

\author{
U.S. GEOLOGICAL SURVEY
}

Gordon P. Eaton, Director

The use of trade, product, or firm names in this report is for identification or location purposes only and does not constitute endorsement of products by the U.S. Geological Survey, nor impute responsibility for any present or potential effects on the natural resources of the United States.

For addtional information write to:

Subdistrict Chief

U.S. Geological Survey

903 Hanshaw Road

Ithaca, NY14850
Copies of this report can be purchased from:

\author{
U.S. Geological Survey \\ Branch of Information Services \\ Box 25286 \\ Denver, CO 80225-0286
}


6. Graphs showing concentrations of selected constituents in surface-water samples collected during above-median flows from Irondequoit Creek above Blossom Road and at Empire Boulevard near Rochester, N.Y., 1991-94. . . . . . . . . . . . . . . . . . . . . . . . . . .

7. Map showing locations of sediment-data-collection sites in Ellison Park wetland, Monroe County, N.Y.

8. Map showing locations of data-collection sites for flora and fish studies in Ellison Park wetland,

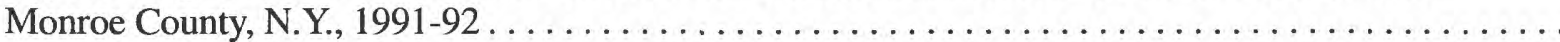

\section{TABLES}

1. Traveltimes of rhodamine dye and peak dye-tracer concentrations in Ellison Park reach of Irondequoit Creek, 1982 and 1991 .

2. Discharges measured and water-surface elevations recorded in 1982 and 1991 during time-of-travel studies in Ellison Park reach of Irondequoit Creek, Monroe County, N.Y. . . . . . . . . . . . . . .

3. Median chemical values for wetfall and dryfall collected in Ellison Park wetland, Monroe County,

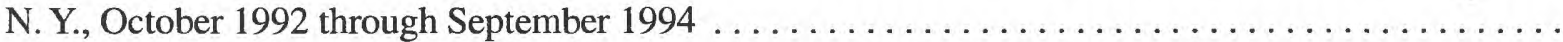

4. Concentrations of selected atmospheric-deposition constituents at three sites in Irondequoit Creek basin, 1980-81, and in Ellison Park wetland, 1992-94, Monroe County, N. Y. . . . . . . . . . . . . .

5. Chemical quality of water from two wells in Ellison Park wetland, Monroe County, N. Y., 1986-89

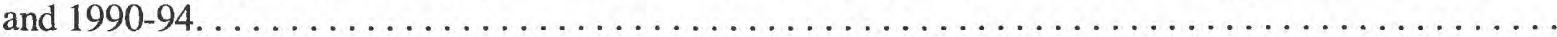

6. Classification and range of particle sizes

7. Size distribution of sediment samples from Ellison Park wetland, Monroe County, N. Y., by

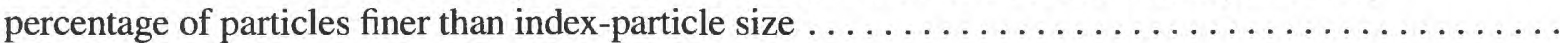

8. Size distribution of sediment samples from Ellison Park wetland, Monroe County, N. Y., by percentage of particles that fall in major particle-size classes

9. Sediment-thickness changes and net sedimentation rates at sedimentation-measurement sites in Ellison Park wetland, Monroe County, N. Y., 1991-95 . . . . . . . . . . . . . . . . . .

10. Mean concentrations of selected elements in sediment samples from Irondequoit Bay (1980) and Ellison Park wetland (1994), Monroe County, N. Y.

11. Average dry-weight concentrations of selected elements in above- and below-ground biomass of Typha glauca collected in Ellison Park wetland, Monroe County, N. Y., 1991

12. Fish species identified in Ellison Park wetland, Monroe County, N. Y., 1991-92 . . . . . . . . . . .

13. Bird species that probably or definitely breed in Ellison Park wetland, Monroe County, N.Y., 1992 . .

\section{APPENDIX TABLES}

A-1. Selected analyses of surface-water samples from Irondequoit Creek at upstream and downstream ends of Ellison Park wetland, for flows above median daily discharge (90 cubic feet per second), March 1991 through December 1994:

A. Irondequoit Creek above Blossom Road, Rochester, N.Y. (station 0423205010) . . . . . . . . .

B. Irondequoit Creek at Empire Boulevard, Rochester, N.Y. (station 0423205025)

A-2. Analyses of ground-water samples from observation wells in vicinity of Ellison Park wetland, Monroe County, N.Y., December 1989 through April 1994

A-3. Analyses of atmospheric deposition in the northern part of Ellison Park wetland, Monroe County, N.Y., April 1992 through September 1994 (station 431021077315902 ) . . . . . . . . . . . . . .

A-4. Analyses of sediment samples collected in the Ellison Park wetland, Monroe County, N.Y., October 1994 


\begin{tabular}{|c|c|c|}
\hline \multicolumn{3}{|c|}{ INCH-POUNDTO INTERNATIONAL SYSTEM (SI) UNITS } \\
\hline Multiply & By & To obtain \\
\hline \multicolumn{3}{|c|}{ Length } \\
\hline inch (in.) & 2.54 & centimeter \\
\hline inch (in.) & 25.4 & millimeter \\
\hline foot $(\mathrm{ft})$ & 0.3048 & meter \\
\hline mile (mi) & 1.609 & kilometer \\
\hline \multicolumn{3}{|c|}{ Area } \\
\hline acre & 0.4047 & hectare \\
\hline square foot $\left(\mathrm{ft}^{2}\right)$ & 0.09290 & square meter \\
\hline square mile $\left(\mathrm{mi}^{2}\right)$ & 2.590 & square kilometer \\
\hline \multicolumn{3}{|c|}{ Volume } \\
\hline cubic foot $\left(\mathrm{ft}^{3}\right)$ & 0.02832 & cubic meter \\
\hline cubic yard $\left(\mathrm{yd}^{3}\right)$ & 0.7646 & cubic meter \\
\hline acre-foot (acre-ft) & 1,233 & cubic meter \\
\hline \multicolumn{3}{|c|}{ Flow rate } \\
\hline cubic foot per second $\left(\mathrm{ft}^{3} / \mathrm{s}\right)$ & 0.02832 & cubic meter per second \\
\hline \multicolumn{3}{|c|}{ Mass } \\
\hline ounce, avoirdupois (oz) & 28.35 & gram \\
\hline pound, avoirdupois (lb) & 0.4536 & kilogram \\
\hline pound per square foot $\left(\mathrm{lb} / \mathrm{ft}^{2}\right)$ & 4,882 & gram per square meter \\
\hline ton, short $(2,000 \mathrm{lb})$ & 0.9072 & megagram \\
\hline \multicolumn{3}{|c|}{ INTERNATIONAL SYSTEM (SI) TO INCH-POUND UNITS } \\
\hline Multiply & By & To obtain \\
\hline \multicolumn{3}{|c|}{ Length } \\
\hline centimeter $(\mathrm{cm})$ & 0.3937 & inch \\
\hline millimeter (mm) & 0.03937 & inch \\
\hline meter $(\mathrm{m})$ & 3.281 & foot \\
\hline kilometer $(\mathrm{km})$ & 0.6214 & mile \\
\hline \multicolumn{3}{|c|}{ Area } \\
\hline hectare (ha) & 2.471 & acre \\
\hline square meter $\left(\mathrm{m}^{2}\right)$ & 10.76 & square foot \\
\hline square kilometer $\left(\mathrm{km}^{2}\right)$ & 0.3861 & square mile \\
\hline \multicolumn{3}{|c|}{ Volume } \\
\hline cubic meter $\left(\mathrm{m}^{3}\right)$ & 35.31 & cubic foot \\
\hline cubic meter $\left(\mathrm{m}^{3}\right)$ & 1.308 & cubic yard \\
\hline cubic meter $\left(\mathrm{m}^{3}\right)$ & 0.0008107 & acre-foot \\
\hline \multicolumn{3}{|c|}{ Flow rate } \\
\hline cubic meter per second $\left(\mathrm{m}^{3} / \mathrm{s}\right)$ & 35.31 & cubic foot per second \\
\hline \multicolumn{3}{|c|}{ Mass } \\
\hline $\operatorname{gram}(\mathrm{g})$ & 0.03527 & ounce, avoirdupois \\
\hline kilogram (kg) & 2.205 & pound avoirdupois \\
\hline gram per square meter $\left(\mathrm{g} / \mathrm{m}^{2}\right)$ & .0002049 & pound per square foot \\
\hline megagram (Mg) & 1.102 & ton, short $(2,000 \mathrm{lb})$ \\
\hline
\end{tabular}

Specific conductance is given in microsiemens per centimeter at 25 degrees Celsius $\left(\mu \mathrm{S} / \mathrm{cm}\right.$ at $\left.25^{\circ} \mathrm{C}\right)$.

Concentrations of chemical constituents in water are given either in: milligrams per liter $(\mathrm{mg} / \mathrm{L}) \approx$ micrograms per gram $(\mathrm{mg} / \mathrm{g})=$ parts per million $(\mathrm{ppm})$; or micrograms per liter $(\mu \mathrm{g} / \mathrm{L}) \approx$ micrograms per kilogram $(\mu \mathrm{g} / \mathrm{kg})=$ parts per billion $(\mathrm{ppb})$

National Geodetic Vertical Datum of 1929 (NGVD) is a geodetic datum derived from a general adjustment of the first-order level nets of both the United States and Canada, formerly called Sea Level Datum of 1929. 


\title{
Hydrology, Sedimentology, and Biology of Ellison Park Wetland at the Mouth of Irondequoit Creek near Rochester, New York
}

\author{
By William F. Coon
}

\section{Abstract}

The Ellison Park wetland, near the mouth of Irondequoit Creek in Monroe County, N.Y., forms a transition zone between the riparian environment of the creek and the lacustrine environment of Irondequoit Bay, an embayment of Lake Ontario. The wetland's proximity to the city of Rochester and its location at the downstream end of an urban and suburban watershed makes it vulnerable to contamination from several sources. Hydrologic, sedimentological, and biological characteristics of the wetland were studied during 1990-94 to provide background data for use in wetland protection and management. The water-surface elevation of nearby Lake Ontario affects water levels in Irondequoit Bay and the adjacent Ellison Park wetland, and water levels in the wetland, in turn, affect many of the hydrologic, sedimentological, and biological processes therein.

Surface-water flows and ground-water levels were monitored. Median daily flow through the wetland was $90 \mathrm{ft}^{3} / \mathrm{s}$ (cubic feet per second). Overbank flows (typically those exceeding $1,000 \mathrm{ft}^{3} / \mathrm{s}$ ) occur twice yearly on average. The wetland attenuates storm-runoff peaks. Time-of-travel studies indicate that stormflows that are confined to the main channel of Irondequoit Creek (up to a bankfull discharge) pass through the wetland in less than 3.5 hours with minimal lateral dispersion. Larger flows result in dispersion (partly through increased diversion to the Millrace channel just north of Blossom Road and partly by overbank flow from the main channel) into the cattailcovered backwater areas of the wetland, where the water can be detained from 3 to 15 hours.

The chemical quality of surface water, ground water, and atmospheric deposition also were monitored. Surface water had high concentrations of sulfate, chloride, zinc, and copper; atmospheric deposition had elevated specific conductance and low $\mathrm{pH}$; and ground water had elevated specific conductance, sodium, chloride, and hardness. These data were generally comparable to data collected at several times during 1979-89 in the Irondequoit Creek basin and to data collected elsewhere within the United States.

Sediment-particle size was measured at 11 sites within the wetland; sand is the predominant bed material in the main channel of Irondequoit Creek, and silt and clay with high concentrations of organic matter cover the backwater areas of the wetland. A historical sedimentation rate of $3 \mathrm{~mm} / \mathrm{yr}$ (millimeters per year) near the mouth of Irondequoit Creek is inferred from measurements of the net rate of postglacial isostatic rebound of the Lake Ontario basin and the consequent rise in water-surface elevation along the southern shore of the lake; recent rates of sedimentation range from 1.9 to $4.9 \mathrm{~mm} / \mathrm{yr}$ and reflect local differences in the depositional environments within the wetland, as well as the effects of episodic deposition and subsequent resuspension and removal of sediment. Chemical analyses of three sediment samples indicate (1) relatively high concentrations of four metals (barium, manganese, strontium, and zinc), and four polynuclear aromatic hydrocarbons (chrysene, fluoranthene, phenanthrene, and pyrene), and (2) the presence of environmentally persistent organochlorine pesticides (chlordane, dieldrin, and degradation products of DDT) and polychlorinated biphenyls. The sediment carried from this urbanized watershed and deposited in the Ellison Park wetland contains high percentages of fine-grained particles and organic matter and thus facilitates the accumulation of these compounds. 
The dominant plant species in the Ellison Park wetland is Typha glauca (cattail). The presence of several other plant species, and measurements of cattail density, height, and biomass, indicate a diverse and highly productive floral ecosystem. Chemical analyses of cattail tissue indicate that concentrations of selected chemical constituents are generally greater in below-ground tissue than in above-ground tissue and that the Ellison Park vegetation contains high concentrations of sodium, iron, aluminum, and manganese.

The wetland supports a diverse fish community and provides spawning and(or) rearing habitat for

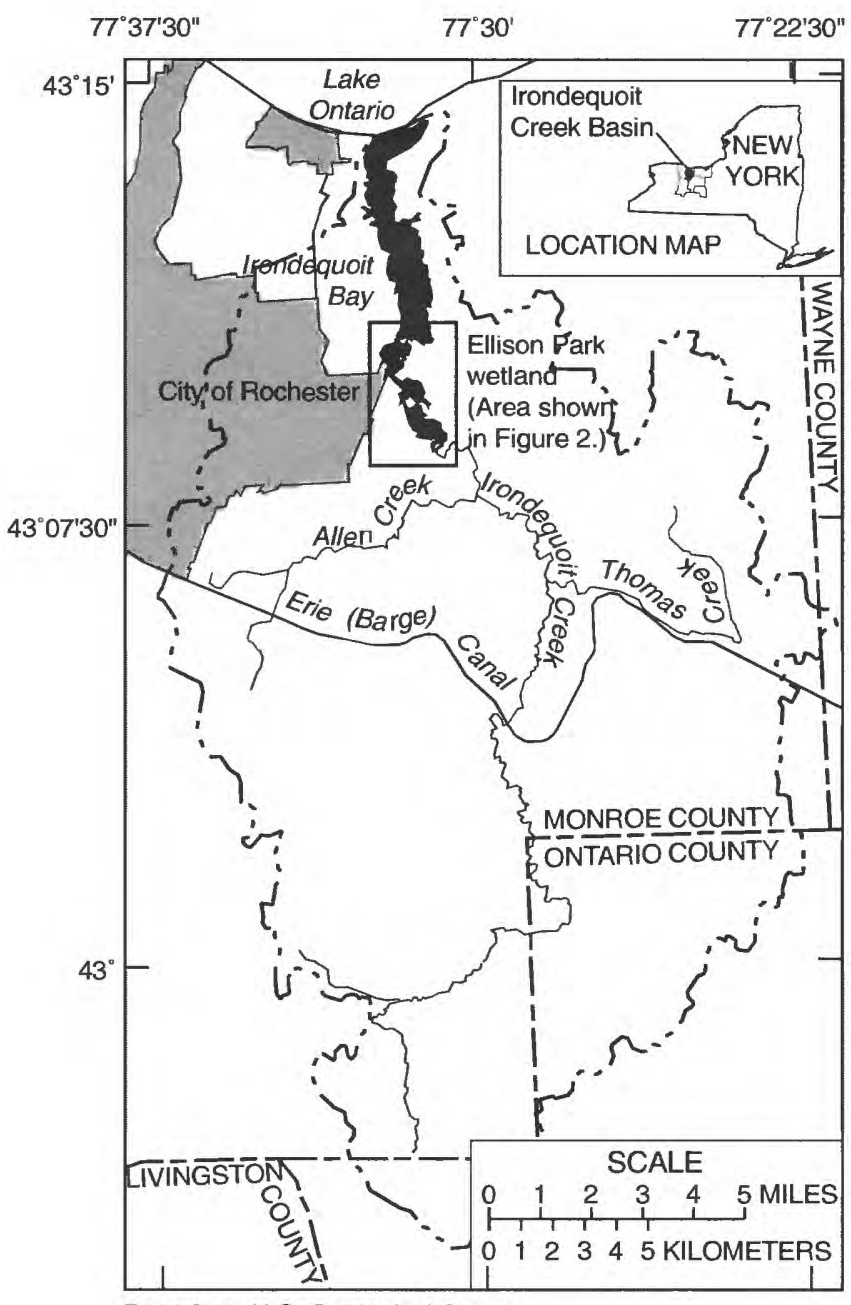

Base from U.S. Geological Survey State base map 1:500,000

Figure 1. Location and major geographic features of Irondequoit Creek basin, Monroe County, N.Y. at least 16 species. The primary macroinvertebrate food sources for fish in the wetland are chironomids (midges) and corixids (true water bugs). Eleven other species of aquatic insects, crustaceans, worms, and crayfish were identified from fish-stomach contents. Abundant populations of painted turtles and snapping turtles thrive in the wetland. A survey conducted during the 1980's identified 95 species of birds in and around the wetland area; seven additional bird species were identified in a 1991-92 study. Of these, 28 species probably or definitely use the wetland for breeding.

\section{INTRODUCTION}

The Irondequoit Bay watershed, which lies southeast and east of the City of Rochester, N.Y., covers an area of $169 \mathrm{mi}^{2}$ (fig. 1). Of this area, $151 \mathrm{mi}^{2}$ is drained by Irondequoit Creek, which terminates at the south end of Irondequoit Bay, . The upstream (southernmost) part of the Irondequoit Creek basin is dominated by forested and agricultural areas, but a large part of the rest of the basin has become urban and residential (O'Brien and Gere, 1983). Sedimentation and eutrophication of Irondequoit Bay have become a major public concern, and Irondequoit Creek is the source of nutrients that support summertime algal blooms, and of sediment to which heavy metals and organic compounds can adhere.

The Irondequoit Creek basin has been studied extensively during the past 20 years by the U.S. Geological Survey (USGS) and by several county departments and university researchers in an attempt to obtain data on the chemical quality and flow characteristics of the creek for use in identifying contaminant sources and evaluating the effects of remediation measures. As a result of these efforts, Monroe County has: (1) decreased the use of roaddeicing salts (Diment and others, 1974; Bubeck and Burton, 1989); (2) routed sewage and storm runoff out of the basin to a central wastewater-treatment facility; (3) enacted zoning and construction ordinances to control storm runoff and erosion; (4) evaluated the capacity of in-stream flow-attenuation basins for storage and infiltration of stormwater (Zarriello and Surface, 1989); (5) constructed runoffdetention basins in residential developments to reduce concentrations of sediment and chemical 
constituents in stormwater (Zarriello and Sherwood, 1993; Zarriello, 1996); and (6) maintained a network of water-quality and streamflow-monitoring stations in the basin. Additional efforts to mitigate eutrophic conditions in Irondequoit Bay include a pilot study on the application of alum to the bay sediments to reduce the release of phosphorus from bottom sediments (Monroe County Department of Health and others, 1984; W.W. Staubitz and R.C. Bubeck, U.S. Geological Survey, written commun., 1995), and artificial oxygenation of the Bay's hypolimnion to improve conditions for game fish (Richard Burton, Monroe County Department of Health, oral commun., 1995).

The hydrologic characteristics of the Irondequoit Creek basin were studied during 1979-81 as part of the Nationwide Urban Runoff Program (NURP) (O'Brien and Gere, 1983; Zarriello and others, 1985; Kappel and others, 1986). One goal of that study was to assess the effect of storm runoff and its associated nutrients and contaminants on the quality of water in Irondequoit Bay. The Irondequoit Creek basin was unique among those studied in the NURP program because it contains an in-stream wetland (fig. 2). After several best-management practices for control of contaminants in urban runoff had been evaluated, this wetland, near the mouth of Irondequoit Creek, was identified as the most cost-effective control measure to reduce nutrient loads to the bay (O'Brien and Gere, 1983).

As a result, Monroe County proposed during the mid-1980's the installation of a flow-control structure on Irondequoit Creek at a point halfway through the wetland to cause stormwater dispersal and detention in the upstream (southern) part of the wetland. Implementation of such a measure required data on present hydrologic and biological conditions within the wetland as a basis for future comparisons and management decisions. Therefore, the USGS, in cooperation with Monroe County Environmental Health Laboratory (MCEHL), began a 4-year study in 1990 to document the hydrologic characteristics and ecological condition of the wetland to provide baseline data from which to assess the effect of flow modification on the wetland.

\section{Purpose and Scope}

This report documents the hydrologic, sedimentological, and biological characteristics of the Ellison

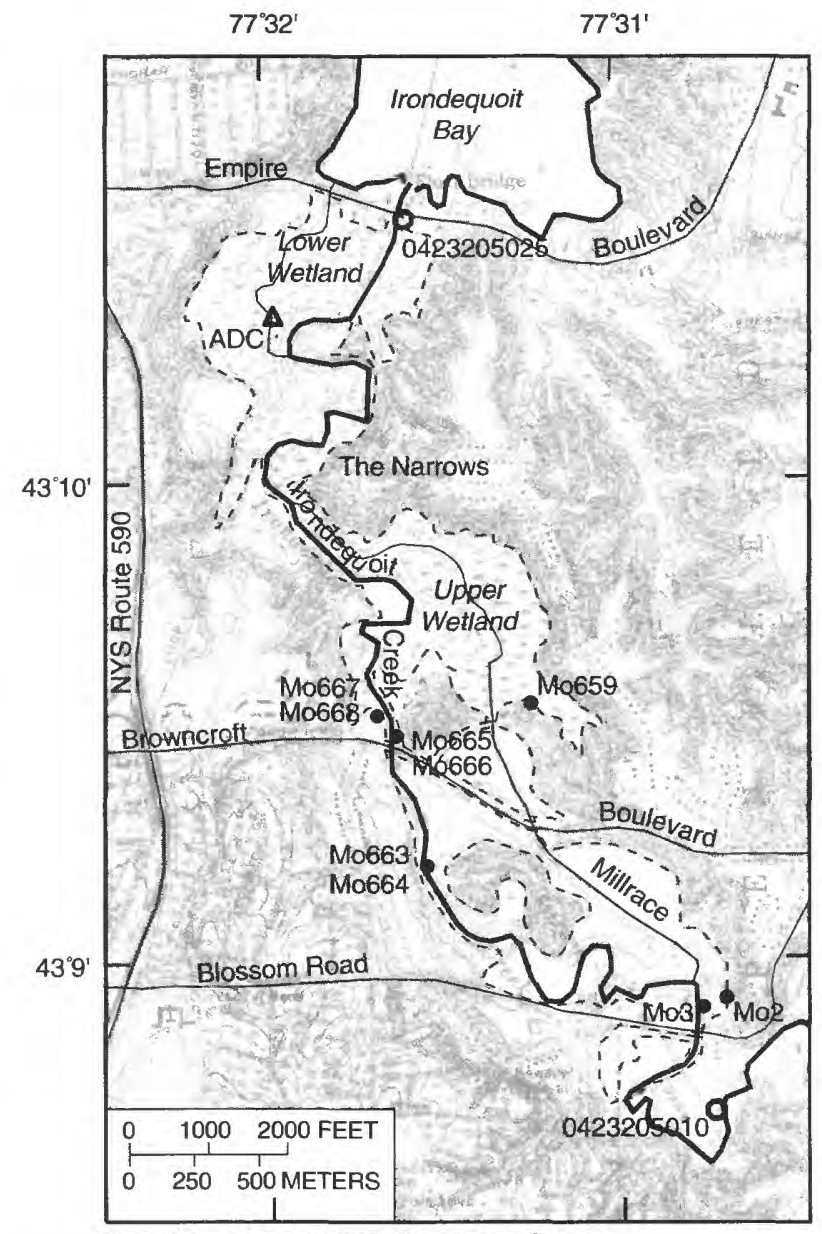

Base from scanned U.S. Geological Survey Rochester East, NY 1:24,000, 1978

\section{EXPLANATION}

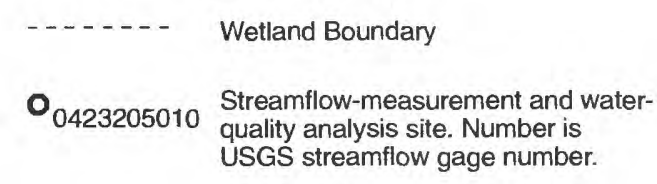

$\triangle$ ADC Atmospheric-deposition collector

- Mo2 Observation well and identification

Figure 2. Locations of data-collection sites in Ellison Park wetland, Monroe County, N.Y. (General location is shown in fig. 1.)

Park wetland. The report (1) summarizes watersurface-elevation and streamflow data; chemical quality of surface water, ground water, and atmospheric deposition; and traveltime and patterns of flow dispersal through the wetland, and (2) presents stream-sediment particle-size analyses, estimated sedimentation rates, and sediment-quality data. It also discusses results of studies of flora and 
selected fauna and includes an appendix containing presents chemical data for surface water, ground water, and atmospheric deposition are given in the appendix.

\section{Acknowledgment}

Thanks are extended to the employees of the Monroe County Environmental Health Laboratory who assisted in the maintenance and operation of the streamflow and water-quality-monitoring sites and analyzed water samples.

\section{ELLISON PARK WETLAND}

The wetland, near the mouth of Irondequoit Creek (fig. 2), forms a transition zone between the riparian environment of the creek and the lacustrine environment of Irondequoit Bay. The wetland encompasses about 423 acres (DeGaspari and Bannister, 1983), most of which lies within the boundaries of Monroe County's Ellison Park (fig. 2), and henceforth is referred to as the Ellison Park wetland. The wetland is bounded by steep valley sides on the east and west and by Irondequoit Bay to the north. DeGaspari and Bannister (1983, p. 3) define the southern extent of the wetland as that area that lies at or below an elevation of $250 \mathrm{ft}$. The wetland converges on the creek just south of Blossom Road (fig. 2). The wetland extends northward from Blossom Road, surrounds two large sand hills of glacial lacustrine origin (Kappel and Young, 1989) on either side of Browncroft Boulevard, then occupies the entire valley floor northward to Irondequoit Bay.

The width of the wetland ranges from $2,500 \mathrm{ft}$ north of Browncroft Boulevard to about $200 \mathrm{ft}$ at a natural constriction locally referred to as "the Narrows" (fig. 2). This constriction is caused by a resistant glacial deposit that impedes lateral erosion of the eastern valley wall. North of this point, the wetland expands to a maximum width of more than $2,500 \mathrm{ft}$ and ends at the mouth of Irondequoit Creek, just north of Empire Boulevard, at the south end of Irondequoit Bay. The manmade boundaries (Browncroft and Empire Boulevards), the steep valley sides, and the constriction at the Narrows impart an hourglass shape to the main area of the wetland, which is vegetated predominantly by cattails, and separates the wetland into an upper segment (south of the Narrows) and a lower segment (north of the Narrows).

\section{Hydrology}

Irondequoit Creek enters the wetland area in a single channel, then branches into two channels about $600 \mathrm{ft}$ downstream from Blossom Road (fig. 2). The main channel meanders to the west side of the valley and roughly follows the valley wall until it passes under Browncroft Boulevard. A smaller channel, locally referred to as the Millrace (because it was formerly the outlet raceway for a flour mill on the east bank of the creek just upstream of Blossom Road), takes a more direct path northward to Browncroft Boulevard. Two culverts (48- and 36-in. diameters) permit diversion of flow to the Millrace just downstream from Blossom Road. Little flow passes through the corrugated-metal culverts during lowflow periods because they are elevated above the bottom of the main channel; this design ensures sustained flow in the main channel during low-flow periods but permits the diversion of excess stormflow into the Millrace during high-flow periods.

The conveyance of the Millrace is limited by the channel cross-sectional area for within-bank flows, and by the bridge opening at Browncroft Boulevard for overbank flows. The main channel of Irondequoit Creek conveys more flow than the Millrace channel because it is larger and has a lower bottom elevation. Discharges measured at Browncroft Boulevard in 1982 and 1991 indicate that, for discharges of 600 to $800 \mathrm{ft}^{3} / \mathrm{s}$, the main channel conveys 73 to 84 percent of the total flow, and that the percentage of flow in the Millrace decreases as the total discharge increases.

Both channels flow into the upper wetland, north of Browncroft Boulevard (fig. 2), where the main channel remains near the west side of the wetland. Flows in the main channel are contained by banks that are higher than the cattail-covered areas beyond. These natural levees are a result of sediment deposition that occurs as overbank flow velocity decreases and sediment is trapped by the dense wetland vegetation along the levee tops.

An extension of the Millrace channel that occupies the east side of the upper wetland (fig. 2) is shallower than the main channel and does not have well-defined banks. High flows are not confined to this channel and easily move into and through the adjacent cattail areas. The shallow bed and the deposition of debris can alter the flow path through the wetland; for example, the open-water channel cut a new path through a cattail-covered area between 
1988 and 1991. The channel through this southeastern part of the wetland ends in a large ponded area that connects with the main channel at two points.

Irondequoit Creek flows through the Narrows along a single channel, then enters the lower wetland (north of the Narrows), where it stays near the eastern side of the valley as it meanders northward. The channel divides halfway through the lower wetland, and a small part of the flow passes through the shallower western section (fig. 2). More than 100 years ago, the creek entered Irondequoit Bay through a southward extension of the embayment along the west side of the valley, and a wooden float bridge spanned the channel at the present location of Empire Boulevard (Maude Frank, Town of Penfield Historian, oral commun., 1995). At present, only a 5 -ft box culvert remains along this western channel to convey water under Empire Boulevard. The culvert carries insignificant amounts of water during low-flow periods but can convey up to about 5 percent of large flows (unpublished data on file in the Ithaca, N.Y., office of the USGS). The main channel of Irondequoit Creek apparently was rerouted to the eastern side of the valley around 1890 (Patricia Wayne, Town of Irondequoit Historian, oral commun., 1995) to facilitate construction of Empire Boulevard, and now passes under Empire Boulevard $900 \mathrm{ft}$ east of the culvert, where a short channel connects the northern end of the wetland with the southern end of Irondequoit Bay.

Wetland conditions in Ellison Park are wholly or partly dependent on the surface elevation of Lake Ontario, which is maintaied within a narrow range through regulation by control structures on the St. Lawrence Seaway. Lake Ontario water-surface elevation directly or indirectly affects: (1) the hydrographic characteristics of Irondequoit Creek near its mouth, (2) dispersal and traveltime of flow through the wetland, (3) sedimentation rates in the wetland, (4) plant diversity and the distribution of cattails (the dominant plant species in the wetland), (5) faunal diversity in the wetland, and (6) fish movement through the wetland. Data collected during 1960-94 indicate that Lake Ontario's median surface elevation was $246.0 \mathrm{ft}$ above National Geodetic Vertical Datum (NGVD) and that, half the time, the lake's surface elevation was between $245.3 \mathrm{ft}$ and $246.8 \mathrm{ft}$, NGVD. Data collected at the Empire Boulevard station during 1990-94 indicate that water-surface elevations in the wetland fluctuated only $4.1 \mathrm{ft}$, from $245.2 \mathrm{ft}$ to
$249.30 \mathrm{ft}$, NGVD. Annual high-water levels occur during May and June, and low-water levels from November through February.

\section{Streamflow}

Streamflow is measured at the upstream and downstream ends of the wetland. The upstream site (USGS stream-flow-gaging station 0423205010 in fig. 2) is 4,000 ft (channel distance) above Blossom Road and is within Ellison Park. The discharge is computed from a continuous record of stage and a stage-to-discharge relation developed from discharge measurements made in the channel nearby or, during high flows, from one of two bridges downstream. The downstream site (station 0423205025) is at Empire Boulevard, in the short channel that connects the wetland to Irondequoit Bay. Discharge computation for this site is more complex than for the upstream (Blossom Road) site because the fluctuating surface elevation of Irondequoit Bay causes continuous and variable backwater. Water velocity in this channel is measured with an acoustic velocity meter (AVM). The AVM velocity reading is correlated with the mean velocity in the channel as calculated from discharge measurements made from the Empire Boulevard bridge. Discharge is computed from this relation and from the relation between stage and flow area. Daily mean discharges for both stations are published annually in the USGS water-resources data reports for western New York State (for example, Hornlein and others, 1995).

\section{Hydrographic Characteristics}

Stormflow hydrographs for Irondequoit Creek above Blossom Road and at Empire Boulevard (fig. 3) reflect the geomorphic characteristics of the channels at these sites and the effect of the intervening wetland area. Stormflows at Blossom Road are characterized by rapid increases in stage and discharge and by sharp peaks, whereas stormflows at Empire Boulevard often have little effect on stage. Even when discharge increases by a factor of 20, the response in stage is sometimes imperceptible (fig. 3A) owing to the backwater effect of Irondequoit Bay causing inundation of the channel to a depth beyond that necessary to efficiently convey flows. Therefore, as discharge increases, water levels in the channel respond slowly, if at all, until the entire flow area becomes effective in conveying water. 
The discharge hydrograph (fig. 3B) indicates that the peak flow at Empire Boulevard, which has been adjusted to include estimated flow through the culvert west of the main channel, typically lags behind that at Blossom Road. The peak at Empire Boulevard is attenuated because (1) the gradient of the channel through the wetland is lower than it is above Blossom Road, and (2) dispersal of flow into the ponded areas of the wetland provides temporary storage. Temporal variations in these hydrographic characteristics result from variations in storm patterns over the basin and the effect of snowmelt.

\section{Flow Duration and Extremes}

Daily mean discharges for Irondequoit Creek above Blossom Road for the period of record (198294) were used in an analysis of flow duration. Median daily discharge in the creek is $90 \mathrm{ft}^{3} / \mathrm{s}$. Median flows (based on monthly daily discharges) range from $54 \mathrm{ft}^{3} / \mathrm{s}$ during the summer to $169 \mathrm{ft}^{3} / \mathrm{s}$ in April (fig. 4), and daily discharges range from 60 to $147 \mathrm{ft}^{3} / \mathrm{s}$ half the time. Most of the major high flows
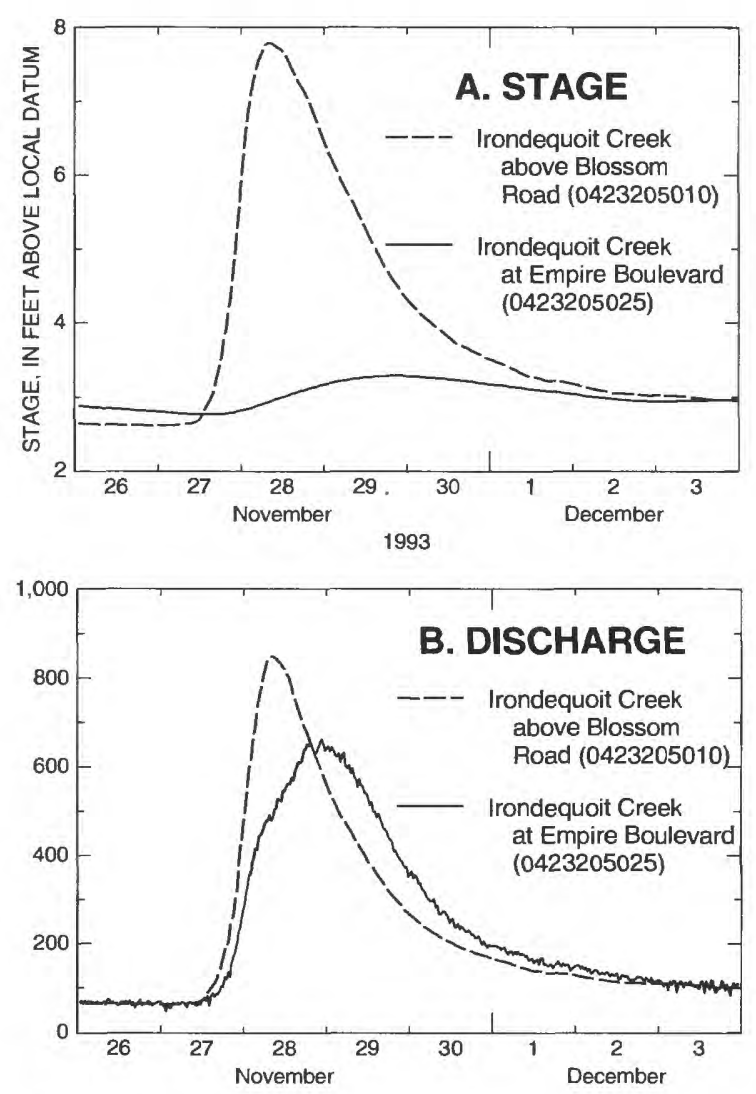

Figure 3. Stage and discharge of Irondequoit Creek above Blossom Road and at Empire Boulevard,near Rochester, N.Y., November 26-December 3, 1993. A. Stage.

B. Discharge. in the basin result from spring rain and snowmelt; other peak flows result from summer thunderstorms. Overbank flows in the wetland occur twice a year on average and usually exceed $1,000 \mathrm{ft}^{3} / \mathrm{s}$. The maximum discharge for the 13-year period of record at the Blossom Road site was $1,710 \mathrm{ft}^{3} / \mathrm{s}$ on April 2, 1993; the minimum recorded discharge was $28 \mathrm{ft}^{3} / \mathrm{s}$ in 1982.

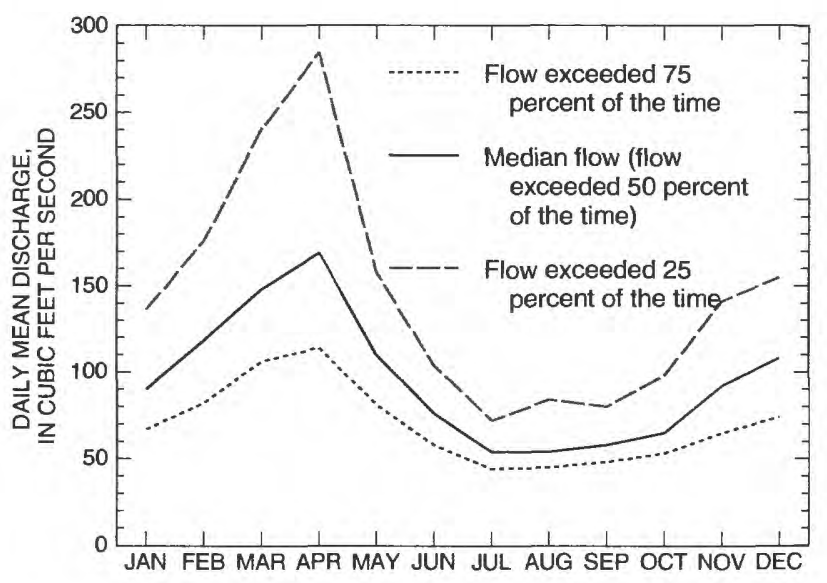

Figure 4. Duration of streamflow at Irondequoit Creek above Blossom Road, Rochester, N.Y., 1982-94

\section{Time of Travel}

Time-of-travel studies were conducted previously on Irondequoit Creek and some of its tributaries by Dunn (1962), and the time of travel along the reach from Blossom Road through the wetland to the Narrows was measured on March 17, 1982 in conjunction with the Nationwide Urban Runoff Program (Kappel and others, 1986). Time of travel and flow dispersion from Blossom Road to Empire Boulevard were measured in the present study on March 28, 1991 and, within the eastern part of the upper wetland, on June 12, 1991. These studies were conducted to (1) measure the time required for a "tagged" volume of water to travel from Blossom Road to the Narrows or Empire Boulevard along the main channel; (2) measure and compare the time required for the same water to move along the Millrace on the east side of the valley from Blossom Road to the Narrows; and (3) document the dispersion characteristics of water moving from the main channel and Millrace into the vegetated areas of the wetland. Rhodamine dye, a biologically inert tracer, was used in these studies in accordance with procedures outlined by Kilpatrick and Wilson (1988). 
A severe ice storm on March 3 and 4, 1991, broke branches and felled trees into the channels between Blossom Road and Browncroft Boulevard. Discharge measurements at Blossom Road documented the backwater effect caused by this debris. The resulting flow impedance caused longer traveltimes in this part of the study reach on March 28, 1991 than were measured during the time-of-travel study on March 17, 1982. Traveltimes through the wetland downstream of Browncroft Boulevard were not affected by debris accumulation at this time.
Traveltimes and peak dye concentrations at the 23 sampling sites are presented in table 1; site locations and traveltimes are shown in figure 5. Measured discharges along the study reach and Irondequoit Bay water-surface elevations are given in table 2.

Water in the main channel of Irondequoit Creek that was tagged with rhodamine dye during high flows took about 2 hours to travel from Blossom Road to the Narrows and an additional 1.5 hours to reach Empire Boulevard. Tagged water in the Millrace took just over 1 hour to reach Old Browncroft Boulevard but

Table 1. Traveltimes of rhodamine dye and peak dye-tracer concentrations in Ellison Park reach of Irondequoit Creek, Monroe County, N.Y., 1982 and 1991

[Locations are shown in fig. 5. do, ditto; <, less than; >, greater than; --, no measurement made; ND, dye not detected above background levels. 1982 data from Kappel and others (1986).]

\begin{tabular}{|c|c|c|c|c|c|c|}
\hline & \multirow[b]{2}{*}{$\begin{array}{c}\text { Sampling-site identification number } \\
\text { and location }\end{array}$} & \multicolumn{3}{|c|}{$\begin{array}{c}\text { Elapsed time from time of dye injection to } \\
\text { collection of peak-dye-concentration } \\
\text { sample, in minutes }\end{array}$} & \multicolumn{2}{|c|}{$\begin{array}{c}\text { Peak dye } \\
\text { concentration, } \\
\text { in parts per billion }\end{array}$} \\
\hline & & $\begin{array}{l}\text { March 17, } \\
1982\end{array}$ & $\begin{array}{l}\text { March 28, } \\
1991\end{array}$ & $\begin{array}{l}\text { June } 12 \\
1991\end{array}$ & $\begin{array}{c}\text { March 28, } \\
1991\end{array}$ & $\begin{array}{c}\text { June 12, } \\
1991\end{array}$ \\
\hline TT1 & service road bridge above Blossom Road & 0 & 0 & -- & -- & -- \\
\hline TT2 & Blossom Road & 5 & 5 & -- & 86 & -- \\
\hline TT3 & Millrace below Blossom Road & -- & 15 & -- & 154 & -- \\
\hline TT4 & Millrace at Browncroft Blvd. & 45 & -- & 0 & -- & -- \\
\hline TT5 & main channel at Browncroft Blvd. & 65 & 87 & -- & 31 & - \\
\hline TT6 & Millrace at Old Browncroft Blvd. & 70 & 64 & 36 & 24 & 96 \\
\hline TT7 & $\begin{array}{l}\text { Millrace extension into eastern part of } \\
\text { upper wetland }\end{array}$ & -- & 95 & -- & 14 & -- \\
\hline TT8 & $\begin{array}{l}\text { eastern part of upper wetland above } \\
\text { confluence with main channel }\end{array}$ & -- & 206 & -- & 3 & -- \\
\hline TT9 & main channel above Narrows & -- & 125 & -- & 26 & -- \\
\hline TT10 & the Narrows & 110 & -- & - & -- & - \\
\hline TT11 & Thompson Creek & - & 155 & -- & 15 & -- \\
\hline TT12 & main channel at Centola Point & -- & $<171$ & - & 16 & -- \\
\hline TT13 & western part of lower wetland & - & 195 & -- & 9 & -- \\
\hline TT14 & main channel at Empire Blvd. & -- & 214 & -- & 9 & -- \\
\hline TT15 & west culvert at Empire Blvd. & - & 378 & -- & 1 & - \\
\hline TT16 & eastern part of upper wetland & -- & -- & 100 & -- & 33 \\
\hline TT17 & $\ldots \ldots \ldots$ do $\ldots \ldots \ldots \ldots$ & -- & -- & 121 & -- & 28 \\
\hline TT18 & $\ldots \ldots \ldots$ do..$\ldots \ldots \ldots$ & -- & -- & 129 & -- & 18 \\
\hline TT19 & $\ldots \ldots \ldots$ do $\ldots \ldots \ldots \ldots$ & -- & - & $>132$ & -- & ND \\
\hline TT20 & $\ldots \ldots \ldots$ do $\ldots \ldots \ldots \ldots$ & -- & -- & 155 & - & 18 \\
\hline TT21 & $\ldots \ldots \ldots$ do $\ldots \ldots \ldots \ldots$ & -- & -- & 170 & -- & 4.6 \\
\hline TT22 & $\ldots \ldots \ldots$ do $\ldots \ldots \ldots \ldots$ & -- & -- & $>191$ & -- & ND \\
\hline TT23 & $\ldots \ldots$ do $\ldots \ldots \ldots \ldots$ & -- & - & $>180$ & - & ND \\
\hline
\end{tabular}




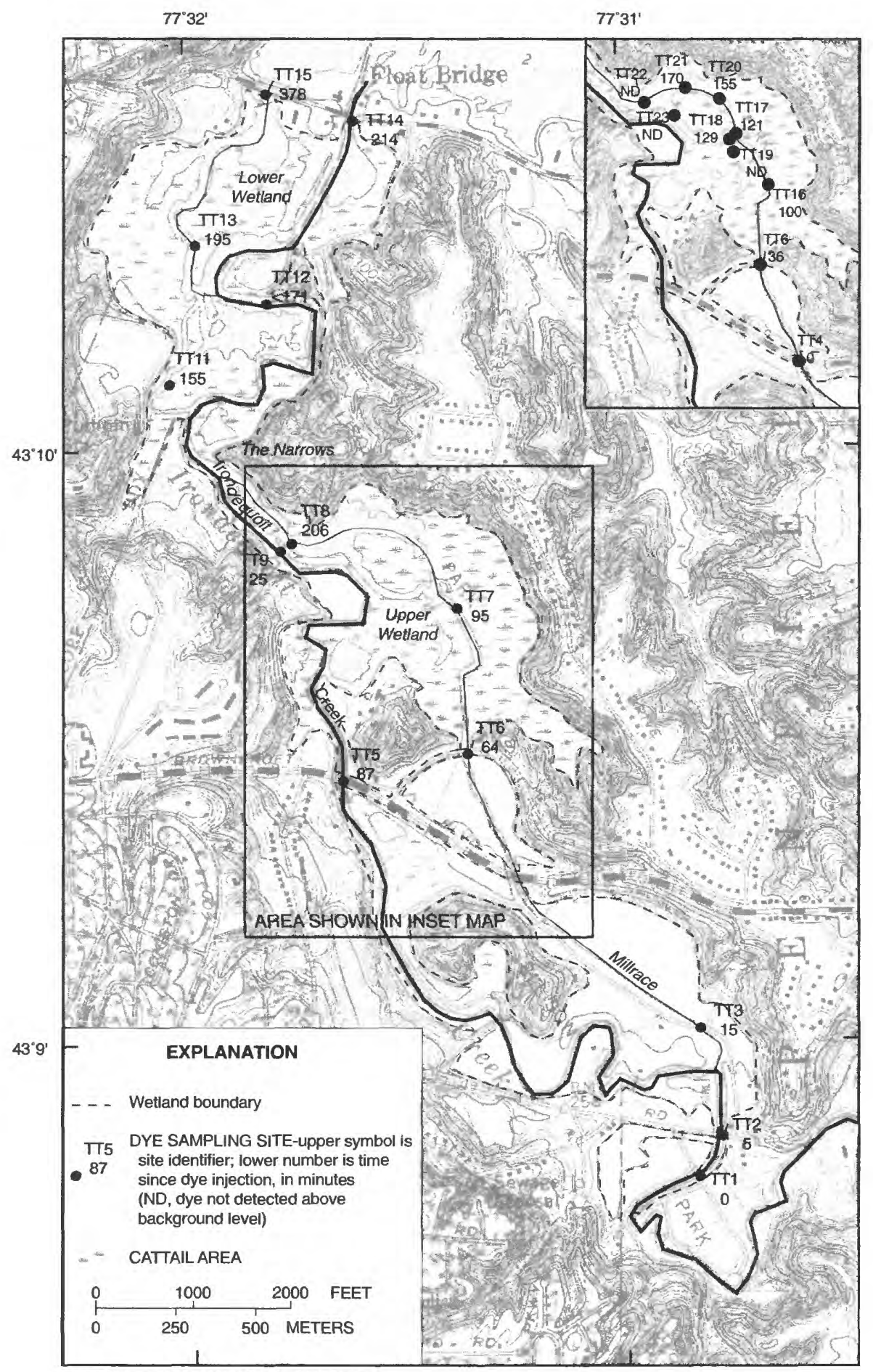

Base from scanned U.S. Geological Survey

Rochester East, NY 1:24,000, 1978

Figure 5. Locations of time-of-travel measurement sites in the Ellison Park wetland, Monroe County, N.Y., and traveltimes of dye tracer on: A. March 28, 1991. B (inset map). June 12, 1991. 
required another 2.5 hours to reach a point just upstream of the Narrows. Tagged water at Empire Boulevard was first detected at the culvert west of the main channel almost 3 hours after the peak concentration in the main channel. Most of the water in the main channel seemingly moves quickly through the wetland, but water that leaves the main channel and flows into the backwater areas of the wetland moves more slowly and is detained in the wetland.

\section{Flow Dispersion and Detention}

Flow-dispersion studies conducted simultaneously with the time-of-travel studies indicate that, for within-bank flows (in the range of 600 to $800 \mathrm{ft}^{3} / \mathrm{s}$ ), most of the water that passes the Millrace diversion just downstream of Blossom Road remains in the main channel, and very little disperses into the cattail areas of the wetland. Flow measurements made during the time-of-travel studies indicate that discharge in the Millrace constitutes only 16 to 27 percent of the total flow measured at Browncroft Boulevard (table 2).

Data from March 1991 and June 1991 suggest that diversion of high flows to the Millrace facilitates dispersion and, possibly, detention of water in the

Table 2. Discharges measured and water-surface elevations recorded in 1982 and 1991 during time-of-travel studies in Ellison Park reach of Irondequoit Creek, Monroe County, N.Y.

[Locations are shown in fig. 2. ---, no measurement made.]

\begin{tabular}{|c|c|c|c|}
\hline Measurement site & $\begin{array}{l}\text { March 17, } \\
1982^{\mathrm{a}}\end{array}$ & $\begin{array}{l}\text { March 28, } \\
1991\end{array}$ & $\begin{array}{c}\text { June } 12 \\
1991\end{array}$ \\
\hline \multicolumn{4}{|c|}{ Discharge, in cubic feet per second } \\
\hline Blossom Road & 740 & 633 & $400^{b}$ \\
\hline $\begin{array}{l}\text { Main channel at Browncroft } \\
\text { Boulevard }\end{array}$ & 695 & 491 & $\ldots$ \\
\hline $\begin{array}{l}\text { Millrace at Browncroft } \\
\text { Boulevard }\end{array}$ & 134 & 180 & 44.4 \\
\hline $\begin{array}{l}\text { Total discharge at Browncroft } \\
\text { Boulevard }\end{array}$ & 829 & 671 & -- \\
\hline The Narrows & 799 & -- & -- \\
\hline Empire Boulevard & -- & $554^{\mathrm{c}}$ & -- \\
\hline \multicolumn{4}{|c|}{$\begin{array}{l}\text { Daily mean water-surface elevations, in feet above } \\
\text { National Geodetic Vertical Datum } \\
\end{array}$} \\
\hline Lake Ontario at Oswego & 245.4 & 247.1 & 247.6 \\
\hline $\begin{array}{l}\text { Irondequoit Bay (at Empire } \\
\text { Boulevard) }\end{array}$ & - & 247.4 & 247.8 \\
\hline
\end{tabular}

a Data from Kappel and others (1986)

b Discharge from recorded stage.

c Discharge is average of two measurements.

d National Geodetic Vertical Datum can be converted to International Great Lakes Datum by subtracting $1.2 \mathrm{ft}$. cattail-covered backwater area within the eastern part of the upper wetland downstream of Browncroft Boulevard. Two sampling points, TT8 and TT9 (table 1 and fig. 5A), which are separated by a narrow, cattail-covered berm and are an equal straight-line distance from the injection point, receive water through different routes. During the March 1991 study, a peak dye concentration of $3 \mathrm{ppb}$ was measured at site TT8 (in the upper wetland area that is fed directly by flow from the Millrace) 81 minutes after a peak dye concentration of $26 \mathrm{ppb}$ was measured at site TT9 in the main channel (table 1). During the June 1991 study (fig. 5B), when a high water-surface elevation in Irondequoit Bay (table 2) caused high backwater conditions, a peak dye concentration of $96 \mathrm{ppb}$ at Old Browncroft Boulevard (site TT6) decreased to less than $5 \mathrm{ppb}$ at the down-stream end of the study reach (site TT21) just over 2 hours later. Dye was undetected above background levels at site TT22, about $500 \mathrm{ft}$ west of TT21 (table 1 and fig. 5B). These results indicate that water entering the eastern part of the upper wetland by way of the Millrace is detained in that area.

In the lower wetland, water that leaves the main channel and enters the northwestern part of the wetland is similarly impeded and detained. The peak dye concentration in the main channel at site TT14 (Empire Boulevard) during the March 1991 study was $9 \mathrm{ppb}$, but only $1 \mathrm{ppb}$ was recorded just over 2.5 hours later at site TT15, at the northwest-outlet culvert $900 \mathrm{ft}$ west of the main channel (fig. 5A). The dye concentration at this site was still above background levels more than 15 hours later, indicating a natural detention of stormflows when water was diverted to the backwater areas of the wetland.

\section{Water Quality}

Water-quality-monitoring stations were operated at the streamflow-monitoring sites (fig. 2). Automatic samplers, which extracted water samples from the channel (near the centroid of flow) hourly and stored them in refrigerated bottles, were maintained by Monroe County Environmental Health Laboratory (MCEHL). MCEHL analyzed the samples for chloride, sulfate, and the common forms of nitrogen and phosphorus. Samples collected during stormflows were analyzed additionally for total organic carbon, biochemical and chemical oxygen demand, alkalinity, specific conductance, suspended solids, and trace metals (cadmium, copper, lead, and zinc). 
An atmospheric-deposition collector (ADC) was installed in the lower wetland about $1,700 \mathrm{ft}$ south of Empire Boulevard (fig. 2) to collect samples monthly. These samples were analyzed by MCEHL for major inorganic ions that characterize wet deposition-nitrate, ammonia, phosphorus, orthophosphorus, sulfate, chloride, sodium, potassium, calcium, and magnesium (Bigelow and Dossett, 1988), as well as two trace metals - lead and zinc. Specific conductance and $\mathrm{pH}$ also were measured as overall indicators of precipitation quality.

\section{Surface Water}

Analyses of surface-water samples collected during 1991-94 at discharges above the median daily discharge of $90 \mathrm{ft}^{3} / \mathrm{s}$ at Blossom Road and Empire Boulevard are summarized in appendix table A-1. Nitrogen and phosphorus concentrations were within the range of those typically found in urbanized basins as reported by Hem (1985). Median concentrations of total nitrogen were 1.9 and $2.0 \mathrm{mg} / \mathrm{L}$ at the Blossom Road and Empire Boulevard monitoring sites, respectively, and median total phosphorus concentrations were about $0.2 \mathrm{mg} / \mathrm{L}$ at both sites (fig. 6). Specific conductance at the two sites (median values of 810 and $818 \mu \mathrm{S} / \mathrm{cm}$, respectively) was high, as would be expected during periods of storm runoff, partly as a result of high concentrations of dissolved solids (sulfate and chloride). High chloride concentrations generally showed a seasonal pattern-concentrations usually were below $100 \mathrm{mg} / \mathrm{L}$ during the summer and fall but exceeded $100 \mathrm{mg} / \mathrm{L}$ and were as high as $390 \mathrm{mg} / \mathrm{L}$ during the winter. This pattern likely reflects wintertime use of road-deicing salts in the basin, the effect of which has been documented by Diment and others (1974). High concentrations of zinc in urban areas are commonly related to its wide distribution in the environment from industrial uses and to its high solubility (Hem, 1985). High zinc concentrations in the Irondequoit Creek basin (median value $60 \mu \mathrm{g} / \mathrm{L}$, maximum $370 \mu \mathrm{g} / \mathrm{L}$ ) might also be due partly to dissociation of zinc sulfide from the dolomite that underlies part of the basin and also is within the overlying glacial deposits and local soils (Kappel and others, 1986, p. 34). Cadmium concentrations generally were below the analytical detection limit $(1 \mu \mathrm{g} / \mathrm{L})$.

Comparison of 1991-94 chemical concentrations of above-median flows at the upstream (Blossom Road) site with those at the downstream (Empire Boulevard) site (fig. 6) indicated higher median concentrations of ammonia and orthophosphorus at the downstream end of the wetland than at the upstream end, whereas median concentrations of ammonia-plus-organic nitrogen and total phosphorus were lower. The median values and ranges of nitrate-plus-nitrite, as well as sulfate and chloride, were similar at both sites. The ranges of copper, lead, and zinc concentrations differed between the two sites, but the median concentrations were similar.

\section{Atmospheric Deposition}

Average annual precipitation in the Rochester area is about 31.5 in., including an average snowfall of about 85 in. (O'Brien and Gere, 1983, p. 30). Atmospheric deposition was collected in a remote location within the lower wetland, $1,700 \mathrm{ft}$ from the nearest road (fig. 2). Under normal operating conditions, the atmospheric-deposition collector (ADC) separates the wet component (wetfall), which includes all forms of precipitation, from the dry component (dryfall), which includes dew, frost, fog, and gravitationally settled particles during periods of no precipitation.

Monthly analyses of atmospheric deposition were divided into wetfall, dryfall, and bulk analyses (appendix table A-3). The wetfall and dryfall samples collected from April through September 1992 were analyzed separately but, because battery failure frequently left both sides of the ADC exposed, the results were stored as if from bulk or composite samples (table A-3, part C). During this period, some samples contained unusually high concentrations of many constituents, presumably through contamination from bird excrement and mud. This was particularly evident in the June-July 1992 bulk sample (table A-3, part C) but was probably a source of error for other samples collected during 1992. Comparison of wetfall with dryfall data from 1992-94 (table 3) suggests that wetfall was slightly more acidic than dryfall and had generally lower concentrations of most constituents. Wetfall values of specific conductance and concentrations of nitrogen and sulfate were neither consistently higher nor lower than dryfall values.

Chemical concentrations of atmospheric deposition from Ellison Park were compared with data presented by (1) Hem (1985), who summarized the results of atmospheric-deposition analyses of samples collected from more than 90 sites randomly located throughout the conterminous United States, 
Table 3. Median chemical values for wetfall and dryfall collected in the Ellison Park wetland, Monroe County, N.Y., October 1992 through September 1994

[Concentrations in milligrams per liter $(\mathrm{mg} / \mathrm{L})$ except where noted $\mu \mathrm{S} / \mathrm{cm}$, microsiemens per centimeter; $\mathrm{CaCO}_{3}$, calcium carbonate.]

\begin{tabular}{lcc}
\hline \multicolumn{1}{c}{ Constituent or physical property } & Wetfall & Dryfall \\
\hline \hline Specific conductance $(\mu \mathrm{S} / \mathrm{cm})$ & 44 & 41.5 \\
$\mathrm{pH}$ (standard units) & 4.2 & 4.85 \\
Acidity (as $\mathrm{CaCO}_{3}$ ) & 6.0 & 5.2 \\
Ammonia (as N) & .60 & .32 \\
Ammonia + organic nitrogen (as N) & .64 & .8 \\
Nitrate + nitrite (as N) & .72 & .845 \\
Phosphorus & .025 & .130 \\
Orthophosphorus (as P) & .006 & .0385 \\
Calcium, dissolved & .58 & 1.30 \\
Calcium, total & .685 & 1.80 \\
Magnesium & .15 & .45 \\
Sodium & .16 & .30 \\
Potassium & .08 & .18 \\
Chloride & .60 & .93 \\
Sulfate & 5.0 & 6.0 \\
Lead & 6 & 8 \\
Zinc & 40 & 40 \\
\hline
\end{tabular}

and (2) Peters and Bonelli (1982), who presented chemical compositions of bulk deposition collected during the winter of 1980-81 at 179 sites in the northcentral and northeastern United States. Concentrations of most constituents measured at the Ellison Park atmospheric-deposition site were near or slightly above the median values reported by Peters and Bonelli (1982) but were within the ranges of concentrations reported by Peters and Bonelli (1982) and by Hem (1985).
Wetfall and dryfall samples also were collected at three sites in the Irondequoit Creek basin during 1980-81; concentrations of phosphorus, nitrogen, lead, and chloride are presented in Zarriello and others (1985). Concentrations of these four constituents measured in Ellison Park samples during 199394 exceeded the range of average seasonal concentrations measured in 1980-81, but the median concentrations obtained during 1993-94 were within the ranges reported for 1980-81 (table 4).

\section{Ground Water}

Ground-water levels and chemical quality were monitored at nine observation wells near Blossom Road and Browncroft Boulevard (fig. 2). Three paired-well installations permitted comparison of water levels and water quality at two depths in the aquifer at a given location. Water levels were measured monthly by MCEHL personnel. Groundwater movement in the unconfined aquifer in the area is from the valley walls toward Irondequoit Creek and northward toward Irondequoit Bay (Yager and others, 1985). High water levels in the creek might cause short-term recharge to the streambank and flood-plain deposits, but generally the Ellison Park wetland is a ground-water discharge point (Kappel and Young, 1989).

Ground-water samples were collected periodically and analyzed by MCEHL for specific conductance, dissolved oxygen, alkalinity, nitrogen, phosphorus, calcium, magnesium, sodium, potassium, chloride, sulfate, iron, and manganese (appendix table A-2). The high values of specific conductance and hardness probably reflect high concentrations of sodium, chloride, calcium, and

Table 4. Concentrations of selected atmospheric-deposition constituents at three sites in Irondequoit Creek basin, 1980-81, and in Ellison Park wetland, 1992-94, Monroe County, N.Y.

[Concentrations in milligrams per liter. 1980-81 data from Zarriello and others (1985).]

\begin{tabular}{|c|c|c|c|c|c|c|c|c|}
\hline \multirow[b]{3}{*}{ Constituent } & \multicolumn{4}{|c|}{ Wetfall concentration } & \multicolumn{4}{|c|}{ Dryfall concentration } \\
\hline & \multirow{2}{*}{$\begin{array}{c}\begin{array}{c}1980-81 \\
\text { Irondequoit Creek } \\
\text { basin }\end{array} \\
\begin{array}{c}\text { Average } \\
\text { seasonal range }\end{array} \\
\end{array}$} & \multicolumn{3}{|c|}{$\begin{array}{c}1992-94 \\
\text { Ellison Park wetland }\end{array}$} & \multirow{2}{*}{$\begin{array}{c}\begin{array}{c}1980-81 \\
\text { Irondequoit Creek } \\
\text { basin }\end{array} \\
\begin{array}{c}\text { Average } \\
\text { seasonal range }\end{array}\end{array}$} & \multicolumn{3}{|c|}{$\begin{array}{c}1992-94 \\
\text { Ellison Park wetland }\end{array}$} \\
\hline & & Ra & ige & Median & & $\mathrm{Ra}$ & ige & Median \\
\hline Total phosphorus & $0.006-0.104$ & $0.005-$ & 0.14 & 0.025 & $0.008-0.432$ & $0.015-$ & 2.05 & 0.130 \\
\hline $\begin{array}{l}\text { Ammonia-plus- organic } \\
\text { nitrogen (as } N \text { ) }\end{array}$ & $.225-1.47$ & $.14-$ & 3.3 & .87 & $.327-2.20$ & $.10-$ & 24 & .80 \\
\hline Lead & $.007-0.019$ & .004 & .025 & .006 & $.006-\quad 0.063$ & $<5-$ & 9 & .008 \\
\hline Chloride & $.116-8.79$ & $.20-$ & 2.6 & .60 & $.292-28.0$ & $.20-$ & 9.2 & .93 \\
\hline
\end{tabular}


magnesium. Specific conductance ranged from $510 \mu \mathrm{S} / \mathrm{cm}$ at well Mo659 to $23,100 \mu \mathrm{S} / \mathrm{cm}$ at well Mo664, and hardness ranged from $90 \mathrm{mg} / \mathrm{L}$ (as calcium carbonate, $\mathrm{CaCO}_{3}$ ) at well $\mathrm{Mo659}$ to $6,900 \mathrm{mg} / \mathrm{L}$ at well Mo664. Nitrogen and phosphorus concentrations were typical of urban environments and comparable to those measured in some of the Ellison Park wells during the mid-1980's (Kappel and Young, 1989). Alkalinity ranged widely from $29 \mathrm{mg} / \mathrm{L} \mathrm{CaCO}$ at well Mo659 to $1,060 \mathrm{mg} / \mathrm{L}$
$\mathrm{CaCO}_{3}$ at well Mo667. High alkalinity concentrations are probably derived from the carbonate sedimentary bedrock that underlies the area.

Data from two wells (Mo2 and Mo3) provided a basis for assessment of changes in ground-water quality over the past 9 years (table 5). Data were collected quarterly and divided into two periods1986-89 and 1990-94. The generally lower median and maximum values during the latter period suggest an overall improvement in ground-water quality.

Table 5. Chemical quality of water from two wells in Ellison Park wetland, Monroe County, N.Y., 1986-89 and 1990-94

[Locations are shown in fig. 2. Concentrations in milligrams per liter except where noted; $\mu \mathrm{S} / \mathrm{cm}$, microsiemens per centimeter; $\mathrm{CaCO}_{3}$, calcium carbonate; <, less than. 1986-89 data from Johnston and Sherwood (1994) and unpublished data on file at Ithaca, N.Y., office of the U.S. Geological Survey.]

\begin{tabular}{|c|c|c|c|c|c|c|}
\hline \multirow[b]{2}{*}{ Constituent or physical property } & \multicolumn{3}{|c|}{$1986-89$} & \multicolumn{3}{|c|}{$1990-94$} \\
\hline & Median & Maximum & Minimum & Median & Maximum & Minimum \\
\hline \multicolumn{7}{|l|}{ A. Well Mo2 (local well number) } \\
\hline Ammonia (as N) & 0.040 & 0.100 & 0.020 & 0.030 & 0.055 & $<0.010$ \\
\hline Ammonia + organic nitrogen (as $\mathrm{N}$ ) & 0.48 & 0.92 & 0.18 & 0.28 & 0.54 & 0.13 \\
\hline Nitrite + nitrate (as N) & 0.010 & 0.300 & $<0.010$ & 0.050 & 0.120 & $<0.050$ \\
\hline Total phosphorus & 0.060 & 0.190 & 0.020 & 0.025 & 0.063 & 0.010 \\
\hline Orthophosphorus (as P) & $<0.005$ & 0.008 & $<0.005$ & 0.002 & 0.037 & $<0.002$ \\
\hline Specific conductance $(\mu \mathrm{S} / \mathrm{cm})$ & 1,020 & 1,080 & 918 & 888 & 1,060 & 807 \\
\hline pH (standard units) & 7.6 & 7.8 & 7.4 & 7.7 & 7.8 & 7.4 \\
\hline Alkalinity (as $\mathrm{CaCO}_{3}$ ) & 202 & 235 & 198 & 180 & 200 & 170 \\
\hline Hardness (as $\mathrm{CaCO}_{3}$ ) & 330 & 400 & 300 & 300 & 320 & 280 \\
\hline Calcium & 90 & 110 & 84 & 82 & 90 & 74 \\
\hline Magnesium & 24 & 30 & 21 & 21 & 23 & 15 \\
\hline Sodium & 83 & 90 & 74 & 70 & 80 & 58 \\
\hline Potassium & 2.0 & 2.6 & 1.5 & 1.5 & 2.1 & 1.2 \\
\hline Chloride & 170 & 190 & 140 & 140 & 150 & 110 \\
\hline Sulfate & 75 & 100 & 72 & 74 & 88 & 38 \\
\hline Iron & 0.89 & 4.50 & 0.27 & 0.40 & 1.60 & 0.20 \\
\hline \multicolumn{7}{|l|}{ B. Well Mo3 (local well number) } \\
\hline Ammonia (as N) & $<0.010$ & 0.020 & $<0.010$ & $<0.010$ & 0.010 & $<0.010$ \\
\hline Ammonia + organic nitrogen (as $\mathrm{N}$ ) & 0.38 & 0.88 & 0.13 & 0.26 & 0.77 & $<0.10$ \\
\hline Nitrite + nitrate (as N) & 0.540 & 0.740 & 0.150 & 0.454 & 0.590 & 0.050 \\
\hline Total phosphorus & 0.030 & 0.235 & 0.010 & 0.010 & 0.030 & 0.005 \\
\hline Orthophosphorus (as P) & $<0.005$ & 0.006 & $<0.005$ & 0.004 & 0.006 & $<0.002$ \\
\hline Specific conductance $(\mu \mathrm{S} / \mathrm{cm})$ & 1,390 & 1,500 & 995 & 1,300 & 1,330 & 1,270 \\
\hline $\mathrm{pH}$ (standard units) & 7.5 & 7.7 & 7.2 & 7.6 & 7.8 & 7.3 \\
\hline Alkalinity (as $\mathrm{CaCO}_{3}$ ) & 250 & 303 & 240 & 240 & 250 & 240 \\
\hline Hardness (as $\mathrm{CaCO}_{3}$ ) & 420 & 470 & 390 & 380 & 390 & 370 \\
\hline Calcium & 120 & 130 & 110 & 110 & 130 & 100 \\
\hline Magnesium & 30 & 38 & 28 & 27 & 33 & 25 \\
\hline Sodium & 130 & 150 & 120 & 130 & 130 & 80 \\
\hline Potassium & 3.3 & 4.3 & 2.6 & 2.8 & 5.2 & 2.1 \\
\hline Chloride & 260 & 270 & 250 & 230 & 250 & 220 \\
\hline Sulfate & 90 & 160 & 78 & 80 & 100 & 15 \\
\hline Iron & 0.800 & 3.20 & 0.15 & 0.15 & 0.46 & 0.07 \\
\hline
\end{tabular}




\section{Sedimentology}

Bed-material particle sizes were analyzed to characterize particle-size distribution and sedimentdepositional environments within the wetland. An attempt was made to measure the current rate of sediment accumulation in the wetland and to compare this rate with an estimated historical sedimentation rate. Four fine-grained sediment samples were collected from three sites in backwater areas of the wetland and analyzed for major and trace elements and organic chemicals, including organochlorine compounds and polynuclear aromatic hydrocarbons.

\section{Particle Size and Distribution}

Bed material was sampled at 11 sites in the wetland (fig. 7) to document particle-size distributions at each site and the areal variation in depositional environments within the wetland. Sites were selected that would represent average bottommaterial composition along the main channel and in the backwater areas of the wetland. Site GS8, just downstream from the Narrows, was selected because it contains coarse material (larger than $4 \mathrm{~mm}$ ) that is found nowhere else in the wetland. Eight sediment samples were separated by sieving into the standard size classes defined by the ranges listed in table 6 . The coarse material collected at site GS 8 by random
Table 6. Classification and range of particle sizes. [From Spencer (1972, p. 163). >, greater than; <, less than.]

\begin{tabular}{lc}
\hline \multicolumn{1}{c}{ Class } & Size range, in millimeters \\
\hline \hline Boulder & $>256$ \\
Cobble & $64-256$ \\
Pebble & $4-64$ \\
Granule & $2-4$ \\
Sand & $0.062-2$ \\
Silt & $0.004-0.062$ \\
Clay & $<0.004$ \\
\hline
\end{tabular}

grab sampling (Wolman, 1954) was measured with a tape. In conjunction with chemical-quality analyses, three samples (GS5, GS6, and GS10) from backwater areas of the wetland were analyzed more precisely by the sieve and pipet methods (Guy, 1969), wherein the sand and coarse fractions are separated by sieving, and the silt and clay fractions are analyzed by the pipet method, which measures the concentration of a suspension at a predetermined depth as a function of settling time. The size distributions of all sediment samples are listed in table 7.

Sand is the predominant bed material in the main channel throughout the wetland, except at the Narrows (sample GS8), where erosion of underlying glacial deposits has resulted in coarse bed material (table 8). Silt and clay are the predominant bed

Table 7. Size distribution of sediment samples from Ellison Park wetland, Monroe County, N.Y., by percentage of particles finer than index-particle size

[Sampling locations are shown in fig. 7. $\mathrm{mm}$, millimeters]

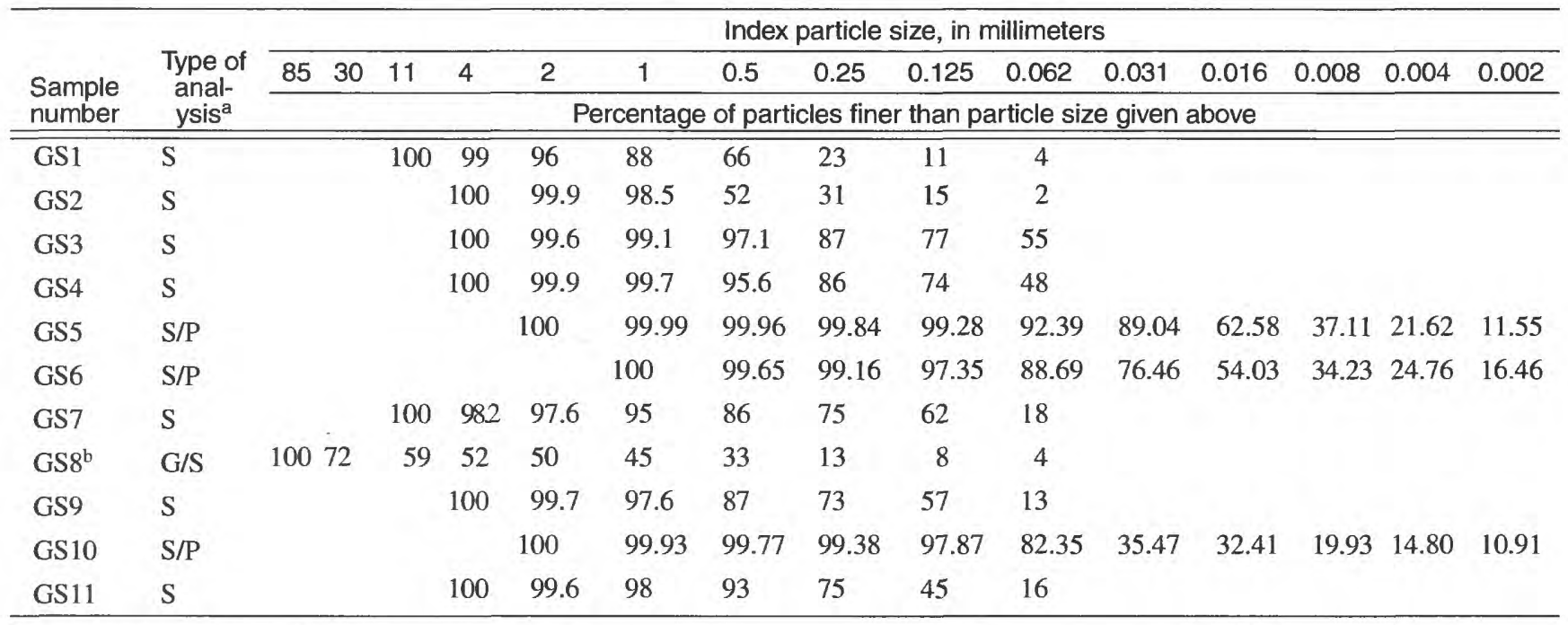

a G, tape measurement of material larger than $11 \mathrm{~mm}$;

$\mathrm{S}$, sieve analysis of material between 11 and $0.062 \mathrm{~mm}$;

$P$, pipet analysis of material smaller than $0.062 \mathrm{~mm}$.

b Percentages are approximate; weight of fraction larger than $30 \mathrm{~mm}$ was estimated. 


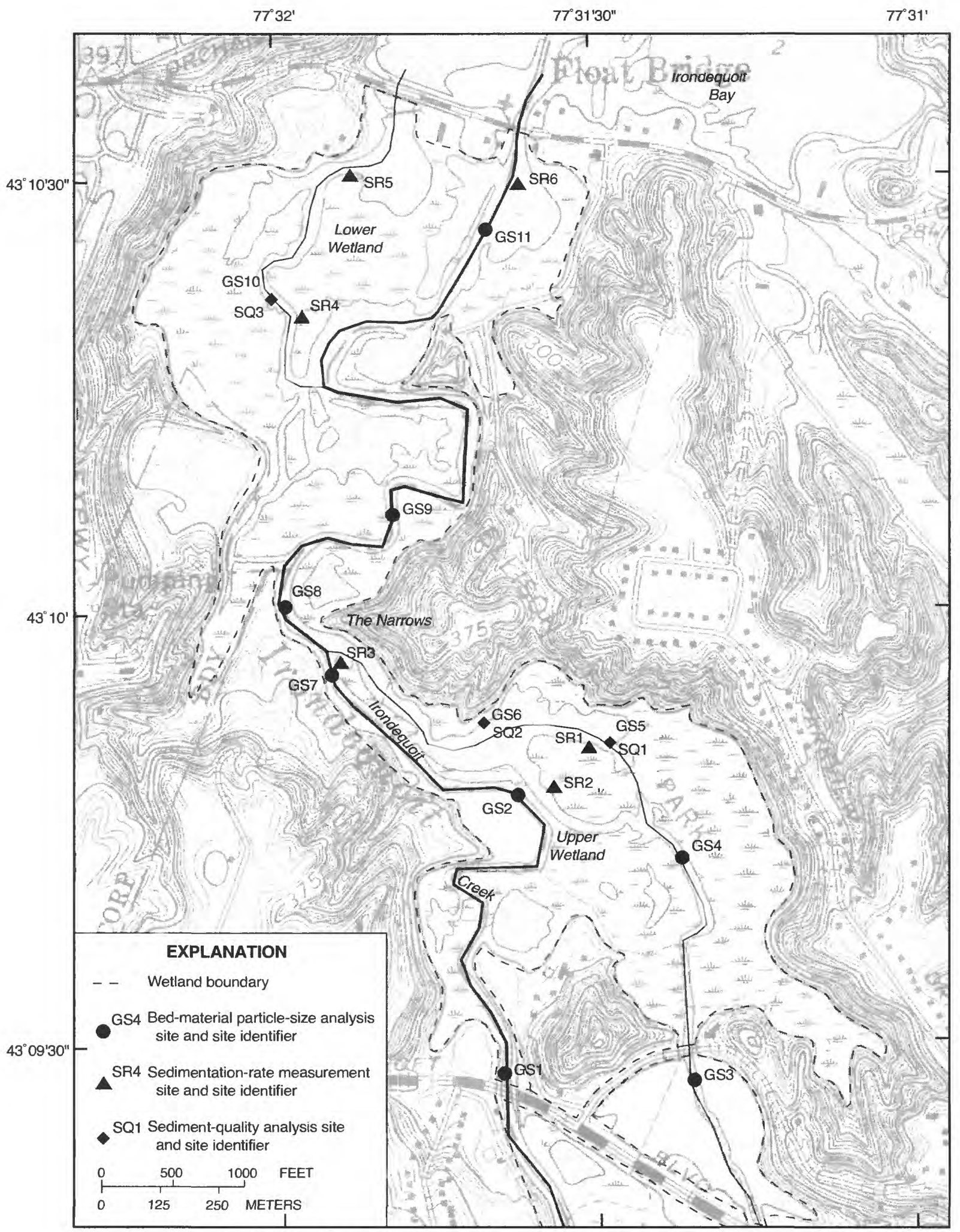

Based from scanned U.S. Geological Survey Rochester East, NY 1:24,000, 1978

Figure 7. Locations of sediment data-collection sites in Ellison Park wetland, Monroe County, N.Y. 
materials in the backwater areas of the wetland, especially in the eastern part of the upper wetland (samples GS5 and GS6) and in the western part of the lower wetland (sample GS10). The sediments in these areas also are high in organic matter (see sediment-quality data, table A-4, for sites SQ1, SQ2, and SQ3, which correspond to particle-size-analysis sites GS5, GS6, and GS10, respectively).

Table 8. Size distribution of sediment samples from Ellison Park wetland, Monroe County, N.Y., by percentage of particles that fall in major particle-size classes

[Locations are shown in fig. 7. --, percentage not determined.]

\begin{tabular}{cccccc}
\hline \multirow{2}{*}{$\begin{array}{c}\text { Sampling } \\
\text { site and } \\
\text { sample num- } \\
\text { ber }\end{array}$} & \multicolumn{5}{c}{$\begin{array}{c}\text { Percentage of sample that falls in given } \\
\text { particle-size class }\end{array}$} \\
\cline { 2 - 6 } & $\begin{array}{c}\text { Larger } \\
\text { than sand }\end{array}$ & Sand & Silt & Clay & $\begin{array}{c}\text { Silt and } \\
\text { Clay }\end{array}$ \\
\hline \hline GS1 & 4 & 92 & -- & -- & 4 \\
GS2 & 0 & 98 & -- & -- & 2 \\
GS3 & 0 & 45 & -- & -- & 55 \\
GS4 & 0 & 52 & -- & -- & 48 \\
GS5 & 0 & 7.61 & 70.77 & 21.62 & 92.39 \\
GS6 & 0 & 11.31 & 63.93 & 24.76 & 88.69 \\
GS7 & 2 & 80 & -- & -- & 18 \\
GS8 & 50 & 46 & -- & -- & 4 \\
GS9 & 0 & 87 & -- & -- & 13 \\
GS10 & 0 & 17.65 & 67.55 & 14.80 & 82.35 \\
GS11 & 0 & 84 & -- & -- & 16 \\
\hline
\end{tabular}

\section{Sedimentation Rate}

The rate of sedimentation near the mouth of Irondequoit Creek has been calculated by Young (1992), and that for Irondequoit Bay by Schroeder (1985). Young (1992) used radiocarbon-dating techniques to estimate historical sedimentation rates from two sediment cores taken at the outlet of Irondequoit Bay and one core from the vicinity of Irondequoit Creek near Browncroft Boulevard; his results indicated the average historical sedimentation rate at the mouth of Irondequoit Creek to be $1 \mathrm{ft}$ per 99 years, or $0.01 \mathrm{ft} / \mathrm{yr}(3 \mathrm{~mm} / \mathrm{yr})$. This rate is consistent with the rate of rise in the water-surface elevation and consequent deepening of the depositional pool along the southern shore of Lake Ontario in response to a differential rate of postglacial isostatic rebound of the Lake Ontario basin. The rate of glacial rebound at the northeastern end (outlet) of Lake Ontario is $1.25 \mathrm{ft}$ per century and, at the southwestern end, is $0.25 \mathrm{ft}$ per century (Clark and Persoage, 1970; Larsen, 1985). Because the lake outlet has been rising faster than the rest of the lake, the water level along the southern shore has been rising at a "differential" rate of about $1.00 \mathrm{ft}$ per century. The rate of sediment accumulation in the vicinity of Irondequoit Bay, as computed by Young (1992), approximates this rate of water-level rise and the resulting deepening of the depositional pool in the area that encompasses the Ellison Park wetland and Irondequoit Bay. Recent and current sedimentation rates could have accelerated as a result of (1) increased erosion from development and agricultural activities in the basin, and (2) aggravated channel erosion resulting from increased runoff from impervious areas, and probably are greater than the historical sedimentation rate.

Schroeder (1985) used lead-210 and cesium-137 radioisotopic-measuring techniques on four bottomsediment cores taken from Irondequoit Bay in 1980 and calculated yearly sediment-accumulation rates of 0.10 to $0.36 \mathrm{~g} / \mathrm{cm}^{2}$ on a dry-weight basis. The calculated thickness of sediment deposited between 1964 (the year of peak cesium-137 concentration in the atmosphere) and 1980 (when the samples were collected) (data from R.A. Schroeder, U.S. Geological Survey, written commun., 1995), indicates a current sedimentation rate of 2.8 to $3.7 \mathrm{~mm} / \mathrm{yr}$. The nonuniform and discontinuous accumulation of sediment reflected in this range of sedimentation rates is probably the result of preferential depositional environments for fine-grained particles and the episodic nature of erosion and deposition in the Irondequoit Creek watershed (Schroeder, 1985).

An estimate of the current rate of sediment accumulation in the Ellison Park wetland was made by anchoring 1-ft-diameter plastic disks in the wetland (locations shown in fig. 7) to provide reference surfaces from which sediment depths could be measured. The disks were placed in depositional environments in the cattail areas of the wetland, near the low-water edges of channels that carry stormflows, and were inspected periodically for changes in sediment thickness (table 9). Sediment thicknesses measured shortly after disk installation were generally larger than those measured later, but all measurements are considered representative of sediment deposition and removal in the vicinity of the disks and were used in sedimentation-rate calculations.

Organic matter, primarily duckweed and decaying cattails, as well as fine-grained sediment, accumulated on the disks in varying amounts. Sediment appears to be deposited and removed from the cattailcovered areas of the wetland in a pattern that would be expected for a system in a state of dynamic 
Table 9. Sediment-thickness changes and net sedimentation rates at sedimentation-measurement sites in Ellison Park wetland, Monroe County, N.Y., 1991-95

[Locations are shown in fig. 7. mm, millimeter; yr, year; --, no data.]

\begin{tabular}{|c|c|c|c|c|c|c|c|c|c|c|}
\hline \multirow{2}{*}{$\begin{array}{c}\text { Site } \\
\text { number }\end{array}$} & \multirow{2}{*}{$\begin{array}{c}\text { Date of } \\
\text { equipment } \\
\text { installation }\end{array}$} & \multicolumn{6}{|c|}{$\begin{array}{l}\text { Change in thickness of sediment from previous inspection, } \\
\text { in millimeters. +, sediment accretion; -, sediment removal }\end{array}$} & \multirow{2}{*}{$\begin{array}{c}\text { Net } \\
\text { sediment } \\
\text { thickness } \\
(\mathrm{mm})\end{array}$} & \multirow{2}{*}{$\begin{array}{c}\text { Period of } \\
\text { data } \\
\text { collection } \\
\text { (years) }\end{array}$} & \multirow{2}{*}{$\begin{array}{c}\text { Net } \\
\text { sedimen- } \\
\text { tation rate } \\
(\mathrm{mm} / \mathrm{yr})\end{array}$} \\
\hline & & 9/92 & $10 / 92$ & $9 / 93$ & 9/94 & $10 / 94$ & $6 / 95$ & & & \\
\hline SR1 & $5 / 29 / 92$ & $a$ & +2 & +14 & -7 & b & -3 & +6 & 3.08 & 1.9 \\
\hline SR2 & $5 / 29 / 92$ & c & +4 & +11 & c & b & -9 & +6 & 3.08 & 1.9 \\
\hline SR3 & $5 / 29 / 92$ & +18 & -2 & 0 & -4 & b & +3 & +15 & 3.08 & 4.9 \\
\hline SR4 & $6 / 91$ & b & +20 & -9 & +4 & b & b & +15 & 3.25 & 4.6 \\
\hline SR5 & $11 / 16 / 93$ & -- & - & -- & d & +30 & d & +30 & 0.92 & $\mathrm{e}$ \\
\hline SR6 & $11 / 16 / 93$ & -- & -- & -- & d & +9 & d & +9 & 0.92 & e \\
\hline
\end{tabular}

a Thin layer of organic matter only

b Sediment disk not inspected

c Sediment disk not found in dense cattail growth

d Sediment disk submerged

e Sedimentation rate not computed; data-collection period too short

equilibrium - episodic deposition of a large quantity of sediment is followed, in subsequent years, by partial resuspension and removal. The net sedimentation rate over the period of data collection ranges from 1.9 to $4.9 \mathrm{~mm} / \mathrm{yr}$ (table 9), with an overall average rate of $3.3 \mathrm{~mm} / \mathrm{yr}$. Lower rates were indicated for the backwater area of the upper wetland, and higher rates were indicated for areas just upstream of the Narrows and the backwater area of the lower wetland. These rates of sedimentation are comparable to the historical rate of $3 \mathrm{~mm} / \mathrm{yr}$ calculated by Young (1992) for a 2,000- to over 11,000-year accumulation period, and encompasses the recent rate of 2.8 to $3.7 \mathrm{~mm} / \mathrm{yr}$ computed from Schroeder's data (R.A. Schroeder, written commun., 1995) for sediment deposited during 1964-80.

\section{Sediment Quality}

The chemical quality of sediment in the Ellison Park wetland was assessed through an analysis of three fine-grained-sediment samples (plus one duplicate sample) collected from the backwater areas of the upper wetland (two sites) and lower wetland (one site) in October 1994. (Locations are shown in fig. 7.) These samples were analyzed for (1) major and trace elements (analytical methods are listed under Schedule 2400 in Timme, 1995), (2) polynuclear aromatic hydrocarbons by gas chromatography with a massspectrometric detector, and (3) organochlorine compounds by gas chromatography with electroncapture detectors (Wershaw and others, 1987). (Results are given in appendix table A-4.) Sampling sites were within long-term depositional areas and distant from channels that might carry high-velocity, erosive flows. Samples were collected under shallow water from the top $10 \mathrm{~cm}$ of sediment.

Results of sediment-quality analyses can be affected by the relative percentages of organic matter and fine-grained particles (silt and clay); therefore, additional samples (GS5, GS6, and GS10) were collected at each site for carbon and particle-size analyses. The samples in these depositional environments contained from 3.4 to 5.0 percent total organic carbon by weight (table A-4, part A) and more than 82 percent silt-size or smaller particles (table 8); these characteristics are conducive to rapid adsorption of organic compounds (Smith and others, 1988) and some metals (Hem, 1985). The measurements of particle size and carbon content permit comparisons of chemical quality between sites, as well as over time at a given site.

High concentrations of some metals (barium, manganese, strontium, and zinc) were found in the Ellison Park sediments (table A-4), but these were in the range expected for an urbanized watershed (E.C. Callender, U.S. Geological Survey, written commun., 1996). A previous sediment-quality study conducted by the USGS in 1980 on sediment cores from Irondequoit Bay included analyses of four samples for selected elements by X-ray fluorescence spectroscopy (R.A. Schroeder, written commun., 1995). Aliquots of sediment from selected depths were dated and analyzed to identify long-term trends in trace-metal concentrations and to document the effects of urban- 
ization in the watershed on the sediment quality of the Bay (Schroeder, 1985). For example, concentrations of lead, copper, and zinc began to increase around 1940 , peaked in the 1960's, and declined in the 1970's. The decline in metal concentrations in the 1970's might reffect a decrease in trace-metal loadings from the basin after elimination of point sources of contamination, that is, routing of sewage and storm runoff out of the basin for treatment (R.A. Schroeder, written commun., 1995). A second explanation could be dilution resulting from increased sedimentation rates (Schroeder, 1985).

Although the analytical method used to determine the element concentrations in the 1980 samples from Irondequoit Bay (x-ray fluorescence spectroscopy) differs from the method used for the 1994 Ellison Park wetland samples (atomic absorption spectrometry), comparison of the two data sets is valid (A.J. Horowitz, U.S. Geological Survey, oral commun., 1996). The mean concentrations of major and trace elements measured in the top $10 \mathrm{~cm}$ of the 1980 sediment cores are presented in table 10; this depth corresponds to that of the 1994 samples. No marked differences are evident except for calcium, lead, and strontium, which are markedly lower in the Ellison Park wetland samples (table 10).

Some polynuclear aromatic hydrocarbons, including chrysene, fluoranthene, phenanthrene, and pyrene, were found in high concentrations in the
Ellison Park sediments, and persistent organochlorine pesticides (chlordane, DDD, DDE, DDT, and dieldrin) and polychlorinated biphenyls (PCB's) also were detected (table A-4, parts B and C). Concentrations of many of the polynuclear aromatic hydrocarbons (PAH's) were higher in the lower wetland (SQ3) (fig. 7) than in the upper wetland (SQ1 and SQ2). Many of these compounds are highly resistant to chemical or biological transformation and, therefore, are extremely persistent in the environment. Nonionic organic compounds, such as chlorinated insecticides, PCB's, and PAH's, have low aqueous solubility and strongly partition from solution to biota, particulate material, and dissolved organic matter (Smith and others, 1988). Therefore, the presence and magnitude of concentrations of these compounds in the organic-rich sediments at the downstream end of this highly urbanized watershed is not surprising, in that large chemical loads were continually discharged from many sewage-treatment plants before the 1980's, when a centralized wastewater-treatment system was installed in the basin. Nevertheless, the concentrations of many of the organo-chlorine pesticides and PCB's in Ellison Park sediments (table A-4, part C) are comparable to or lower than those measured in 14 studies in the United States during the 1970's and 1980's, as reported in Smith and others $(1988$, p. 33).

Table 10. Mean concentrations of selected elements in sediment samples from Irondequoit Bay (1980) and Ellison Park wetland (1994), Monroe County, N.Y.

[Locations of Ellison Park wetland sites are shown in fig. 7. ppm, parts per million. Irondequoit Bay data from R.A. Schroeder. U.S. Geological Survey, written commun., (1995). All samples are from top 10-centimeter depth.]

\begin{tabular}{|c|c|c|c|c|c|c|}
\hline \multirow[b]{3}{*}{ Element } & \multicolumn{5}{|c|}{ Irondequoit Bay, 1980} & \multirow{3}{*}{$\begin{array}{c}\text { Ellison Park wetland, } 1994 \\
\text { Mean of } \\
\text { three samples }\end{array}$} \\
\hline & \multicolumn{4}{|c|}{ Core-site identification $^{\mathrm{a}}$} & \multirow{2}{*}{$\begin{array}{l}\text { Mean of } \\
\text { four cores }\end{array}$} & \\
\hline & Deep & Ides & Center & West & & \\
\hline Aluminum (percent) & 4.0 & 2.6 & 5.4 & 8.0 & 5.0 & 4.9 \\
\hline Potassium (percent) & 1.4 & 1.3 & 1.8 & 1.4 & 1.5 & 1.6 \\
\hline Calcium (percent) & 14.6 & 16.0 & 10.6 & 10.6 & 13.0 & 6.0 \\
\hline Iron (percent) & 2.40 & 1.94 & 2.75 & 2.48 & 2.39 & 2.6 \\
\hline Lead, ppm & 98 & 117 & 94 & 136 & 111 & 66 \\
\hline Zinc, ppm & 228 & 247 & 243 & 197 & 229 & 230 \\
\hline Copper, ppm & 82 & 66 & 85 & 64 & 74 & 80 \\
\hline Titanium, ppm & 1,900 & 1,840 & 2,680 & 2,350 & 2,190 & 2,600 \\
\hline Manganese, ppm & 884 & 433 & 722 & 738 & 694 & 710 \\
\hline Strontium, ppm & 686 & 681 & 499 & 530 & 599 & 400 \\
\hline
\end{tabular}

a "Deep" core is from center of bay, about halfway between N.Y. State Route 104 and Lake Ontario;

"Ides" core is from from Ides Cove, on west side of northern half of bay;

"Center" and "West" cores are from center and west side, respectively, of southern half of bay just south of where Densmore Creek enters bay from the west. 


\section{Biology}

Flora and fauna are integral components of the Ellison Park wetland and were assessed to characterize its ecological quality. The flora of the wetland were studied by DeGaspari and Bannister (1983) and by Bernard and Seischab (1991). Miller and Ringler (1992) studied the fish community of the wetland and also conducted a bird survey, turtle counts, and macroinvertebrate identification (through fishstomach-contents analysis). A comprehensive survey of birds in the area was conducted during 1980-85 (Andrle and Carroll, 1988) as part of a statewide program to map breeding ranges of birds in New York State.

\section{Flora}

DeGaspari and Bannister (1983) conducted a flora survey of the upper wetland area during the summer of 1983. The study area encompassed the part of the wetland that lies south of the Narrows in which land surface is at or below an elevation of $250 \mathrm{ft}$ (fig. 2). The southern limit of this area is the Irondequoit Creek channel just south of Blossom Road. Seven categories of terrain and associated vegetation were identified. The dominant plant species in the "marsh" areas of the wetland were cattails, including broad-leaf cattails (Typha latifolia), narrow-leaf cattails (Typha angustifolia), and a hybrid species that has intermediate characteristics. Diverse plant communities were found in the areas of transition from wet to dry conditions on levees (narrow strips of ground along the main creek channel and 1 to $3 \mathrm{ft}$ above water level) and along the perimeter of the wetland. No endangered, threatened, or rare species were identified.

A comprehensive study of the wetland flora and vegetation between Empire and Browncroft Boulevards was conducted during 1991 by Bernard and Seischab (1991). The study included: (1) identification of individual species, (2) mapping of plant communities, (3) measurements of plant density and above- and below-ground biomass, and (4) chemical analyses of above- and below-ground tissues of cattails. Ten wetland plant communities were identified, mainly on the basis of frequency and duration of inundation. The dominant genus was Typha. Some taxonomists disagree on the speciation of cattails in the wetland (Bernard and Seischab, 1991); some assign the cattails in the area to three distinct species (T. latifolia, T. angustifolia, and T. glauca), whereas others believe $T$. glauca to be a hybrid of the other two. Bernard and Seischab (1991) identified the dominant cattail species as T. glauca. Only a few small areas clearly contained $T$. latifolia;

T. angustifolia was not found in the area studied.

Typha dominates the major habitat in the wetland-flat, seasonally inundated areas at elevations just above the annual median water level. The greatest plant diversity is in dry habitats, either in high areas bordering streambanks within the wetland or along the border between wetland and upland. No rare or endangered species were found in the wetland.

\section{Cattail Density and Biomass}

Bernard and Seischab (1991) established one transect each across the upper and lower wetland areas (fig. 8), along which square-meter plots were located every $10 \mathrm{~m}$ and marked with 1.5 -in PVC pipe. Thirty-one plots were marked in the upper wetland and 26 in the lower wetland. The height of the cattail shoots and the cattail density, the latter averaging 32 and 31 shoots per square meter in the upper and lower wetland areas, respectively, were measured at each of the plots during June or July 1991. Water depth was the primary factor controlling the density and growth of cattails; depths from 3 to $15 \mathrm{in}$. above the soil surface provided an environment most conducive to cattail growth (Bernard and Seischab, 1991, p. 10); drier or wetter conditions resulted in a decrease in cattail density, and drier conditions encouraged development of more diverse plant assemblages.

Typha biomass was measured between August 15 and September 10, 1991, and was found to be related to water depth and cattail density. Average above-ground biomass was $2,094 \mathrm{~g} / \mathrm{m}^{2}$ in the upper wetland and $2,368 \mathrm{~g} / \mathrm{m}^{2}$ in the lower wetland. Average below-ground biomass was $2,707 \mathrm{~g} / \mathrm{m}^{2}$ in the upper wetland and $3,291 \mathrm{~g} / \mathrm{m}^{2}$ in the lower wetland. From these data, Bernard and Seischab (1991, p. 11) estimated that the above-ground biomass of the well-developed cattail marsh in the Ellison Park wetland approaches $2,230 \mathrm{~g} / \mathrm{m}^{2}$, and the below-ground biomass approaches $3,000 \mathrm{~g} / \mathrm{m}^{2}$. Combining these two values gives a total biomass estimate of $5,230 \mathrm{~g} / \mathrm{m}^{2}$. Productivity estimates of freshwater marshes typically exceed $1,000 \mathrm{~g} / \mathrm{m}^{2}$ but can be as high as $6,000 \mathrm{~g} / \mathrm{m}^{2}$ (Mitsch and Gosselink, 1986). Thus, the Ellison Park wetland would be considered a highly productive floral ecosystem. 


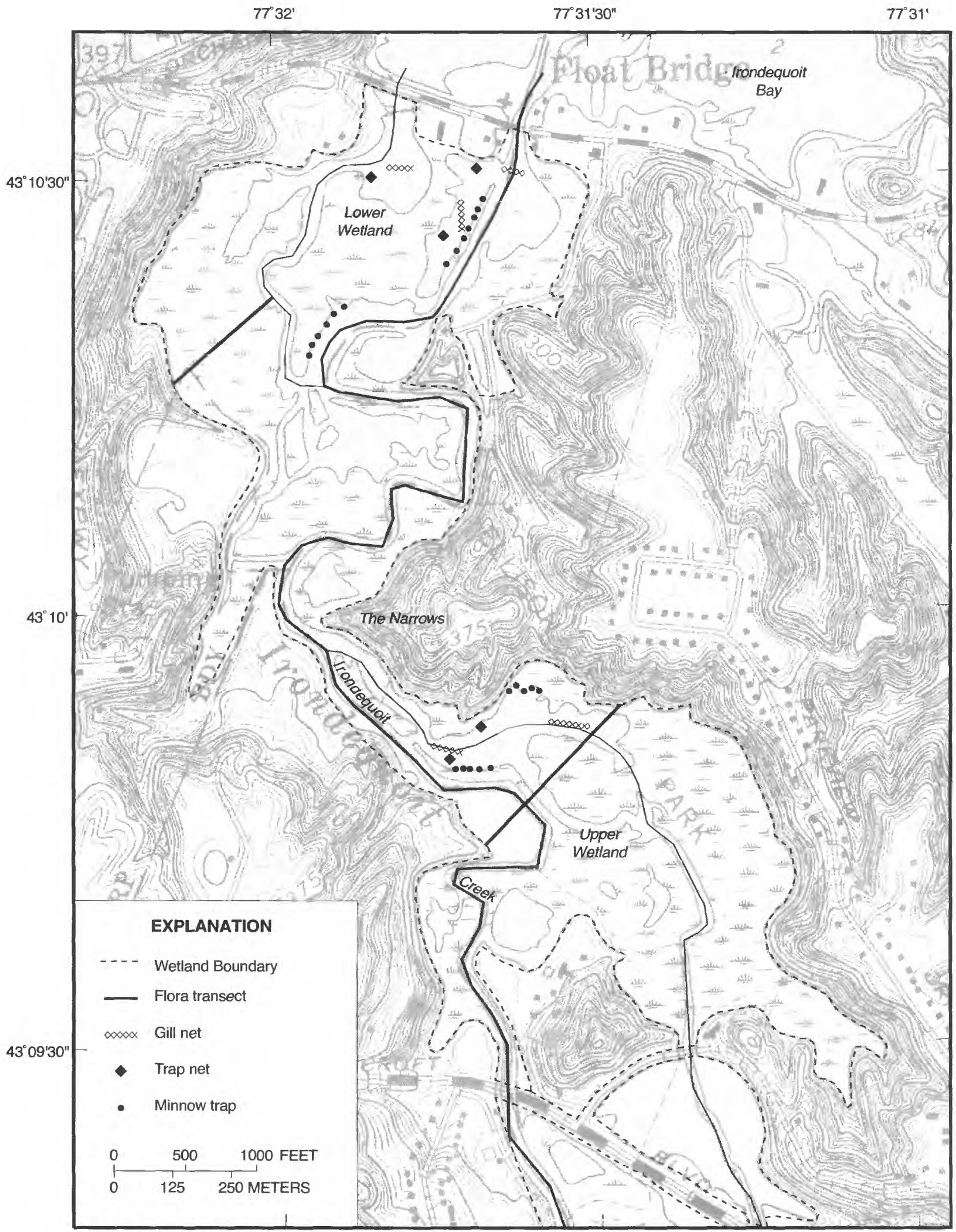

Base from scanned U.S. Geological Survey

Rochester East, NY 1:24,000, 1978

Figure 8. Locations of data-collection sites for flora and fish studies in Ellison Park wetland, Monroe County, N.Y., 1991-92 


\section{Plant-Tissue Analyses}

Bernard and Seischab (1991) harvested vegetation from each of the permanently marked plots and analyzed above- and below-ground plant tissues for metals (copper, nickel, chromium, cobalt, molybdenum, zinc, aluminum, iron, lead, boron, and manganese) and nutrients (calcium, potassium, magnesium, sodium, phosphorus, and nitrogen) (table 11). Most elements, especially aluminum, sodium, and iron, were found in higher concentrations in the belowground biomass than in the above-ground biomass; the average below-ground concentrations were: aluminum, 1,880 ppm; sodium, $10,000 \mathrm{ppm}$; and iron, $18,000 \mathrm{ppm}$ (table 11). Elements whose above-ground concentrations were greater than below-ground values were manganese, potassium, nitrogen, and phosphorus. Data summarized by Hutchinson (1975) and Vitosh and others (1973) indicate that the concentrations of most constituents of the Ellison Park biomass generally were within ranges typical in aquatic plants; exceptions were manganese and sodium in aboveground tissues, and aluminum, iron, manganese, and sodium in below-ground tissues; concentrations of these constituents were higher than typically reported.

Table 11. Average dry-weight concentrations of selected elements in above- and below-ground biomass of Typha glauca collected in Ellison Park wetland, Monroe County, N.Y., 1991

[Data from Bernard and Seischab (1991). ppm, parts per million; $<$, less than. Percentage values are by weight.]

\begin{tabular}{lcc}
\hline \multicolumn{1}{c}{ Element } & $\begin{array}{c}\text { Above-ground } \\
\text { plant tissue }\end{array}$ & $\begin{array}{c}\text { Below-ground } \\
\text { plant tissue }\end{array}$ \\
\hline Copper, ppm & 5.3 & 15.6 \\
Nickel, ppm & 1.6 & 9.6 \\
Chromium, ppm & 1.4 & 6.0 \\
Cobalt, ppm & $<0.1$ & 0.6 \\
Molybdenum, ppm & 0.4 & 0.6 \\
Zinc, ppm & 17.5 & 59.8 \\
Aluminum, ppm & 17.3 & 1,880 \\
Iron, ppm & 67.4 & 18,000 \\
Lead, ppm & 0.6 & 18.9 \\
Boron, ppm & 12.1 & 132 \\
Manganese, ppm & 598 & 458 \\
Sodium, ppm & 3,600 & 10,000 \\
Calcium, percent & 1.0 & 1.3 \\
Magnesium, percent & 0.2 & 0.5 \\
Potassium, percent & 1.4 & 0.4 \\
Nitrogen, percent & 2.6 & 0.8 \\
Phosphorus, percent & 0.25 & 0.2 \\
\hline
\end{tabular}

In comparing these results with the reported values for cattails at two other study sites (a natural marsh in South Carolina and a constructed wetland in New York receiving landfill leachate), Bernard and Seischab (1991, p. 8) noted that the chemical composition of the Ellison Park vegetation was generally within the range observed at the other sites, but that the Ellison Park plants had much higher concentrations of sodium, presumably as a result of winter road-salt application in the basin.

The standing stock of an element in an ecosystem is the total mass of that element computed as the product of the element's concentration and the total biomass of the ecosystem. Total average standing stocks of selected elements in the above- and belowground tissues of the Ellison Park wetland were computed as follows: nitrogen, $69.3 \mathrm{~g} / \mathrm{m}^{2}$; phosphorus, $9.9 \mathrm{~g} / \mathrm{m}^{2}$; and potassium, $36.5 \mathrm{~g} / \mathrm{m}^{2}$. These high values reflect the large biomass of the wetland and are comparable to those of other Typha glauca communities for which similar data are available (Bernard and Seischab, 1991).

\section{Fauna}

A survey of fauna within the Ellison Park wetland conducted during 1991-92 by Miller and Ringler (1992) focused on the fish of the wetland but also collected data to characterize turtle, bird, and macroinvertebrate communities. This survey was intended to establish baseline information that could be compared with results of future studies to identify changes in the wetland fauna. Ornithological data were collected during $1980-85$ by local ornithological groups in conjunction with a statewide program to identify breeding ranges of birds in New York State (Andrle and Carroll, 1988). Data from this census were used to characterize the bird population in the Ellison Park wetland.

Fish

Trap nets, minnow traps, and gill nets were used by Miller and Ringler (1992) to capture fish during July 1991 and May 1992 (fig. 8). Low-water conditions during September 1991 prohibited the use of trap nets; therefore a bag seine was used. Captured fish were identified, measured, and weighed. Results indicated a diverse fish community with at least 37 species (table 12). The most abundant species include alewife, gizzard shad, bluegill, pumpkinseed, black crappie, white perch, brown bullhead, bluntnose minnow, and spottail shiner. Other common 
species are carp, golden shiner, and largemouth bass. Ten rare species were identified by the capture of only one individual for each species during the three trapping periods. The main predators are bowfin and northern pike. The presence or capture of juvenile or spawning fish indicates that the wetland is a spawning and(or) rearing habitat for at least 16 fish species, and the presence of adults, together with known habitat requirements and life histories, indicates that six other species presumably use the wetland for spawning and rearing (Miller and Ringler, 1992). Brown bullhead appear to be year-round residents. The presence of migratory salmonids (brown trout and rainbow trout) indicates the wetland to be a pathway between spawning areas in Irondequoit Creek upstream of the wetland and Irondequoit Bay and Lake Ontario.

Seventeen species of fish were not randomly distributed throughout the wetland during either the July 1991 or May 1992 fish-capturing periods. Of

Table 12. Fish species identified in Ellison Park wetland, Monroe County, N.Y., 1991-92

[Data from Miller and Ringler (1992).]

\begin{tabular}{|c|c|c|c|}
\hline Common name & Scientific name & $\begin{array}{c}\text { Relative } \\
\text { abundance }\end{array}$ & $\begin{array}{l}\text { Uses wetland for } \\
\text { spawning or rearing } \\
\text { (yes, no, presumed) } \\
\text { or migration only }\end{array}$ \\
\hline Longnose gar & Lepisosteus osseus & Rare & No \\
\hline Bowfin & Amia calva & Common & Yes \\
\hline Alewife & Alosa pseudoharangus & Abundant & Yes \\
\hline Gizzard shad & Dorosoma cepedianum & Abundant & Yes \\
\hline Brown bullhead & Ameiurus nebulosus & Abundant & Yes \\
\hline Quillback & Carpiodes cyprinus & Rare & No \\
\hline White sucker & Catostomus commersoni & Uncommon & Yes \\
\hline Shorthead redhorse & Moxostoma macrolepidotum & Rare & No \\
\hline Goldfish & Carassius auratus & Uncommon & No \\
\hline Common carp & Cyprinus carpio & Common & Yes \\
\hline Rudd & Scardinius erythrophthalmus & Uncommon & No \\
\hline Central stoneroller & Campostoma anomalum & Rare & Yes \\
\hline Golden shiner & Notemigonus crysoleucas & Common & Yes \\
\hline Spotfin shiner & Cyprinella spiloptera & Common & No \\
\hline Emerald shiner & Notropis atherinoides & Uncommon & Yes \\
\hline Rosyface shiner & Notropis rubellus & Rare & No \\
\hline Spottail shiner & Notropis hudsonius & Abundant & No \\
\hline Mimic shiner & Notropis volucellus & Rare & No \\
\hline Bluntnose minnow & Pimephales notatus & Abundant & Presumed \\
\hline Fathead minnow & Pimephales promelas & Rare & No \\
\hline Rainbow trout & Oncorhynchus mykiss & Uncommon & Migration \\
\hline Brown trout & Salmo trutta & Uncommon & Migration \\
\hline Central mudminnow & Umbra limi & Rare & Presumed \\
\hline Northern pike & Esox lucius & Common & Presumed \\
\hline Trout-perch & Percopsis omiscomaycus & Uncommon & Presumed \\
\hline Banded killifish & Fundulus diaphanus & Rare & No \\
\hline Brook silverside & Labidesthes sicculus & Common & Presumed \\
\hline White perch & Morone americana & Abundant & Yes \\
\hline Green sunfish & Lepomis cyanellus & Rare & No \\
\hline Pumpkinseed & Lepomis gibbosus & Abundant & Yes \\
\hline Bluegill & Lepomis macrochirus & Abundant & Yes \\
\hline Rock bass & Ambloplites rupestris & Uncommon & Yes \\
\hline Smallmouth bass & Micropterus dolomieu & Uncommon & Yes \\
\hline Largemouth bass & Micropterus salmoides & Common & Yes \\
\hline Black crappie & Pomoxis nigricans & Abundant & Yes \\
\hline Johnny darter & Etheostoma nigrum & Common & Presumed \\
\hline Yellow perch & Perca flavescens & Uncommon & No \\
\hline
\end{tabular}


these species, four showed a consistent preference for either the lower or upper part of the wetland. Larger numbers of spotfin shiner, bluntnose minnow, and black crappie were captured in the upper wetland than in the lower wetland during both periods, whereas brown bullhead seemed to prefer the lower wetland (Miller and Ringler, 1992).

In comparison with the results of 10 surveys of fish in Irondequoit Bay that were conducted between 1937 and 1991, the present fish community of the Ellison Park wetland is more diverse than the Irondequoit Bay community has been since 1937 . One reason could be that water quality in the wetland is improving and allowing recovery of several fish species, especially minnows and shiners (Miller and Ringler, 1992).

\section{Macroinvertebrates}

The aquatic macroinvertebrate community of the wetland was analyzed on the basis of the stomach contents of 99 fishes of 9 species (Miller and Ringler, 1992). Thirteen taxa of macroinvertebrates were identified, generally to the lowest taxonomic level possible. The predominant insect families were Chironomidae (midges) and Corixidae (true water bugs), which represented 82.5 and 14.5 percent, respectively, of the total insect population identified by this method. Other insect taxa included Trichoptera (caddis flies), Plecoptera (stone flies), Zygoptera (damsel flies), Veliidae (water striders), Hydrachnidia (water mites), Circulionidae (weevils). Other taxa identified were Cladocera (crustaceans: daphnia, bosmina), Copepoda (copepods), Amphipoda (scuds), Oligochaeta (earthworms), and Astracidae (crayfish). Although this sampling method provided general information on the macroinvertebrate community, the results cannot be considered comprehensive; the actual macroinvertebrate composition could be more diverse and also would change seasonally, depending on the availability of particular macroinvertebrates as food sources and on the selectivity of feeding fish (Miller and Ringler, 1992). Population estimates cannot be derived from data obtained by this method.

\section{Birds}

The New York State Department of Environmental Conservation and the Federation of New York State Bird Clubs conducted a statewide survey during 1980-85 to identify bird species and map the extent of their breeding ranges; results are summarized in the Atlas of Breeding Birds in New York State by Andrle and Carroll (1988). A compilation of the results of this study, presented as lists of species by survey area and breeding category, lists 95 species of birds as possible, probable, or confirmed breeders in the area that includes the Ellison Park wetland. Of these, 25 species typically or sometimes use wetland habitat for breeding, and of these, 16 are considered ground nesters (table 13).

During 1991-92, Miller and Ringler (1992) identified 30 species of birds by sight or call. Of these, 23 species are included in the list of species identified in the Ellison Park wetland during the 1980-85 statewide breeding survey, and 8 are listed by Andrle and Carroll (1988) as probable or confirmed Ellison Park wetland breeding birds (table 13). Of the 7 species that were not previously identified (within the wetland) in the statewide survey, three are wetland breeders: (1) the pied-billed grebe, which builds nests that are free-floating or anchored to emergent vegetation but whose breeding status in Ellison Park is uncertain (Robert Spahn, Genesee Ornithological Association, written commun., 1995); (2) the Canada goose, which has been observed on ground nests in the wetland; and (3) the American coot, which builds a floating platform attached to emergent vegetation, but probably does not use the Ellison Park wetland for breeding (Robert Spahn, written commun., 1995).

Most ground-nesting birds build nests near the water's edge, either free-floating (such as the piedbilled grebe), on dry ground amid the wetland vegetation (such as the mallard and common moorhen), or on slightly elevated tussocks of grass or dead vegetation (such as the American bittern and common snipe). Some birds, including the marsh wren, Virginia rail, and common yellowthroat, attach nests to emergent vegetation above the ground or water level, and others, such as the ring-necked pheasant, veery, and yellow warbler, prefer the drier nesting conditions along the margin of the wetland.

\section{Turtles}

Miller and Ringler (1992) identified abundant populations of both painted and snapping turtles in the wetland. Using a mark-and-recapture method, they estimated the population size of painted turtles to be $478( \pm 227)$ in the upper wetland. 
Table 13. Bird species that probably or definitely breed in the Ellison Park wetland, Monroe County, N.Y., 1992

\begin{tabular}{|c|c|c|c|c|c|}
\hline \multirow[b]{2}{*}{ Common name } & \multirow[b]{2}{*}{ Scientific name } & \multicolumn{2}{|c|}{ Identified } & \multirow{2}{*}{$\begin{array}{l}\text { Ground } \\
\text { nesting }\end{array}$} & \multirow[b]{2}{*}{ Nesting location } \\
\hline & & $1980-85^{a}$ & $1991-92^{b}$ & & \\
\hline American bittern & Botaurus lentiginosus & $\mathrm{X}$ & $\mathrm{X}$ & Yes & $\begin{array}{l}\text { On tussock or platform } 4 \text { to } 18 \text { inches above } \\
\text { water level. }\end{array}$ \\
\hline Least bittern & Ixobrychus exilis & $\mathrm{X}$ & & Yes & $\begin{array}{l}\text { Mat supported by previous year's emergent } \\
\text { growth } 1 \text { to } 4 \text { feet above water. }\end{array}$ \\
\hline Pied-billed grebe & Podilymbus podiceps & & $\mathrm{X}$ & Yes & $\begin{array}{l}\text { Free-floating or anchored to emergent vegeta- } \\
\text { tion; uncertain breeding status }{ }^{c}\end{array}$ \\
\hline Canada goose & Branta canadensis & & $\mathrm{X}$ & Yes & Dry ground or elevated spots. \\
\hline Mallard & Anas platyrhynchos & $\mathrm{X}$ & $\mathrm{X}$ & Yes & Dry ground or elevated spots. \\
\hline Blue-winged teal & Anas discors & $\mathrm{X}$ & & Yes & $\begin{array}{l}\text { Dry ground amid cattails; probably no longer } \\
\text { present. }\end{array}$ \\
\hline Wood duck & Aix sponsa & $\mathrm{X}$ & & No & Cavities in trees. \\
\hline Ring-necked pheasant & Phasianus colchicus & $\mathrm{X}$ & & Yes & Ground along dry edge of wetland. \\
\hline Virginia rail & Rallus limicola & $\mathrm{X}$ & & Yes & $\begin{array}{l}\text { Above water or ground amid emergent vegeta- } \\
\text { tion. }\end{array}$ \\
\hline Common moorhen & Gallinula chloropus & $\mathrm{X}$ & & Yes & Near water level amid emergent vegetation. \\
\hline Sora & Porzano carolina & $\mathrm{X}$ & & Yes & $\begin{array}{l}\text { About } 6 \text { inches above water amid emergent } \\
\text { vegetation. }\end{array}$ \\
\hline American coot & Fulica americana & & $\mathrm{X}$ & Yes & $\begin{array}{l}\text { Floating platform attached to emergent vegeta- } \\
\text { tion; uncertain breeding status }{ }^{c} \text {. }\end{array}$ \\
\hline Killdeer & Charadrius vociferus & $X$ & $\mathrm{X}$ & Yes & Open gravelly areas along dry edge of wetland. \\
\hline American woodcock & Scolopax minor & $\mathrm{X}$ & & Yes & $\begin{array}{l}\text { Dry ground along edge or elevated spots within } \\
\text { wetland. }\end{array}$ \\
\hline Common snipe & Gallinago gallinago & $\mathrm{X}$ & & Yes & Dry ground or on grass tussock. \\
\hline Spotted sandpiper & Actitis macularia & $\mathrm{X}$ & $\mathrm{X}$ & Yes & Ground along dry edge of wetland. \\
\hline Belted kingfisher & Ceryle alcyon & $\mathrm{X}$ & $\mathrm{X}$ & No & Excavated hole in sandy bank. \\
\hline Alder flycatcher & Empidonax alnorum & $X$ & & No & Brush and trees. \\
\hline Willow flycatcher & Empidonax traillii & $X$ & & No & Shrubs. \\
\hline Marsh wren & Cistothorus palustrus & $X$ & $\mathrm{X}$ & No & 1 to 3 feet above water lashed to vegetation. \\
\hline Veery & Catharus fuscescens & $X$ & & Yes & Ground or low shrubs along wetland edge. \\
\hline Blue-gray gnatcatcher & Polioptila caerulea & $X$ & & No & Trees. \\
\hline Yellow warbler & Dendroica petechia & $X$ & & No & Shrubs or brush along wetland edge. \\
\hline Cerulean warbler & Dendroica cerulea & $\mathrm{X}$ & & No & Trees. \\
\hline $\begin{array}{l}\text { Common yellow- } \\
\text { throat }\end{array}$ & Geothlypis trichas & $X$ & & No & $\begin{array}{l}\text { Within few inches of ground attached to } \\
\text { vegetation. }\end{array}$ \\
\hline Red-winged blackbird & Agelaius phoeniceus & $X$ & $\mathrm{X}$ & Yes & Near or above water surface or ground. \\
\hline Swamp sparrow & Melospiza georgiana & $X$ & & Yes & $\begin{array}{l}\text { Few inches above ground or } 1 \text { foot above } \\
\text { water amid emergent vegetation. }\end{array}$ \\
\hline Song sparrow & Melospiza melodia & $X$ & $\mathrm{X}$ & Yes & Ground or elevated in catttails or low trees. \\
\hline
\end{tabular}

${ }^{\text {a }}$ Based on listing of species compiled during New York State Department of Environmental Conservation and the Fedeation of New York State Bird Clubs Breeding Bird Atlas Project (Andrle and Carroll, 1988) and on records from Robert Spahn, Genesee Ornithological Association, written commun., 1995)

${ }^{\mathrm{b}}$ Miller and Ringler (1992)

${ }^{c}$ Robert Spahn, Genesee Ornithological Association, written commun., 1995 


\section{SUMMARY}

The Ellison Park wetland, near the mouth of Irondequoit Creek in Monroe County, forms a transition zone between riparian and lacustrine environments. Its environmental quality has been affected by the large nearby urban area centered around Rochester. Hydrologic, sedimentological, and biological characteristics were studied to provide a background database for future reference in management and protection of this wetland resource.

Water levels in the Ellison Park wetland, which fluctuated only about $4 \mathrm{ft}$ during 1990-94, are maintained through regulation of the water-surface elevation in Lake Ontario by control structures on the St. Lawrence Seaway. This water-level stability is a critical component of the wetland ecosystem and directly or indirectly affects: (1) the hydrographic characteristics of Irondequoit Creek near its mouth,

(2) flow dispersal and traveltime through the wetland, (3) sedimentation rates, (4) plant diversity and the areal extent of cattails (the dominant plant species in the wetland), and (5) faunal diversity in and fish movement through the wetland.

Streamflow was monitored at the upstream and downstream ends of the wetland (above Blossom Road and at Empire Boulevard, respectively). Median daily flow through the wetland, based on 13 years of recorded data, was $90 \mathrm{ft}^{3} / \mathrm{s}$; extreme flows range from a maximum of more than $1,700 \mathrm{ft}^{3} / \mathrm{s}$ to a minimum of $28 \mathrm{ft}^{3} / \mathrm{s}$. Overbank flows (usually exceeding $1,000 \mathrm{ft}^{3} / \mathrm{s}$ ) occur twice yearly on average. The wetland between the two monitoring sites attenuates storm-runoff peaks. Time-of-travel studies indicate that stormflows conveyed primarily in the main channel of Irondequoit Creek (up to a bankfull discharge of about $900 \mathrm{ft}^{3} / \mathrm{s}$ ) pass through the wetland in less than 3.5 hours. Some diversion to the Millrace channel (just north of Blossom Road) occurs, but lateral dispersal from the main channel is minimal. Dispersion of larger flows (greater than $900 \mathrm{ft}^{3} / \mathrm{s}$ ) occurs partly through increased diversion to the Millrace channel and by overbank flow from the main channel. Dispersed water moves into the cattail-covered backwater areas of the wetland, where it can be detained from 3 to 15 hours (the upper limit of detention time has not been determined).

Surface-water quality was monitored at both ends of the wetland, and atmospheric deposition was monitored in the lower wetland. Surface water had elevated concentrations of sulfate, chloride, zinc, and copper; atmospheric deposition had elevated specific conductance and low $\mathrm{pH}$. Comparison with data from sites elsewhere in the United States indicates that the concentrations of these and other constituents in surface water and atmospheric deposition generally are within the range expected for an urbanized watershed. In addition, the atmospheric-deposition concentrations of selected elements are within the ranges measured in the Irondequoit Creek basin during 1980-81.

Ground-water levels and chemical quality were monitored at nine wells in the wetland. The direction of ground-water movement in the unconfined aquifer is from the valley walls toward Irondequoit Creek and northward toward Irondequoit Bay. High water levels in Irondequoit Creek might cause short-term recharge from the creek to the streambank and flood-plain deposits, but generally the wetland is a ground-water discharge area. High specific conductance and hardness values in ground water reflect residential and urban land use in the basin, as well as the chemical composition of local bedrock and glacial deposits.

Sediment particle sizes were measured at 11 sites within the wetland; sand is the predominant bed material in the main channel of Irondequoit Creek, and silt and clay, with a high concentration of organic matter, are predominant in the backwater areas. Sedimentation in the wetland was sporadic during 1991-95 and reflected a pattern of episodic deposition of a large quantity of sediment followed, in subsequent years, by partial resuspension and removal. Net sedimentation rates ranged from 1.9 to $4.9 \mathrm{~mm}$ per year. Radiocarbon dating of sediment cores from near the mouth of Irondequoit Creek suggests an average historical sedimentation rate of about $3 \mathrm{~mm}$ per year.

Three fine-grained sediment samples-two from the upper wetland and one from the lower wetlandwere analyzed for major and trace elements.concentrations of barium, manganese, strontium, and zinc were elevated in relation to those in nonurbanized watersheds elsewhere in the United States. Comparison of these results with data collected from Irondequoit Bay in 1980 indicates no marked differences in the sediment quality at each location, except for calcium, lead, and strontium, which were markedly lower in the 1994 Ellison Park wetland samples. The samples were also analyzed for organic compounds. 
Some polynuclear aromatic hydrocarbons, including chrysene, fluoranthene, phenanthrene, and pyrene, were detected in relatively high concentrations, and persistent organochlorine pesticides (chlordane, DDD, DDE, DDT, and dieldrin) and polychlorinated biphenyls (PCB's) were detected. The presence and magnitude of concentrations of these compounds are fairly typical of a depositional environment at the downstream end of a highly urbanized watershed in which the bottom sediment is characterized by high percentages of fine-grained particles and organic matter.

The dominant plant species in the Ellison Park wetland is Typha glauca (cattail), but diverse habitats, distinguished by the degree and frequency of inundation, support a wide variety of plant life. Cattail density, height, and biomass indicate a highly productive floral ecosystem. Analyses of cattail tissue indicate that concentrations of selected chemical constituents in below-ground tissue were generally higher than in above-ground tissue. The cattails contained higher concentrations of sodium, iron, aluminum, and manganese than are typical for aquatic plants. Total average standing stocks (or total mass of selected elements in the wetland vegetation) for above- and below-ground tissues were estimated to be: $69.3 \mathrm{~g} / \mathrm{m}^{2}$ of nitrogen, $9.9 \mathrm{~g} / \mathrm{m}^{2}$ of phosphorus, and $36.5 \mathrm{~g} / \mathrm{m}^{2}$ of potassium.

The Ellison Park wetland supports a diverse fish community with at least 37 species, 16 of which use the wetland for spawning and(or) rearing. Results of two fish-capturing periods in 1991 and 1992 indicate that four species show a preference for the upper or lower parts of the wetland. Spotfin shiner, bluntnose minnow, and black crappie were captured in larger numbers in the upper wetland, and the brown bullhead was captured in greater numbers in the lower wetland. The primary macroinvertebrate food sources for fish in the wetland are chironomids (midges) and corixids (true water bugs). Other macroinvertebrates identified include various aquatic insects, crustaceans, worms, and crayfish. The wetland also supports large populations of painted turtles and snapping turtles. A bird survey conducted during the 1980's identified 95 species of birds in and around the wetland area; seven additional species were identified in 1991-92. Of these 102 species, 28 probably or definitely use the wetland for breeding.

\section{REFERENCES CITED}

Andrle, R.F., and Carroll, J.R., 1988, The atlas of breeding birds in New York State: Ithaca, N.Y., Cornell University Press, $551 \mathrm{p}$.

Bernard, J.M., and Seischab, F.K., 1991, Flora and vegetation of the Irondequoit Creek and Buttonwood Creek wetlands: Unpublished report on file in the Ithaca, N.Y., office of the U.S. Geological Survey, $49 \mathrm{p}$.

Bigelow, D.S., and Dossett, S.R., 1988, Instruction manual NADP/NTN site operation: National Atmospheric Deposition Program, Natural Resource Ecology Laboratory, Fort Collins, Colo., Colorado State University, $102 \mathrm{p}$.

Bubeck, R.C., and Burton, R.S., 1989, Changes in chloride concentrations, mixing patterns, and stratification characteristics of Irondequoit Bay, Monroe County, New York, after decreased use of road-deicing salts, 19741984: U.S. Geological Survey Water-Resources Investigations Report 87-4223, 52 p.

Clark, R.H., and Persoage, N.P., 1970, Some implications of crustal movement in engineering planning: Canadian Journal of Earth Sciences, v. 7, p. 628-633.

DeGaspari, C., and Bannister, T.T., 1983, Survey of the Irondequoit Creek wetlands-possible effects of shortterm impoundment of storm water behind a proposed flow-regulating structure at the Narrows: Irondequoit Bay Report No. 13, 21 p.

Diment, W.H., Bubeck, R.C., and Deck, B.L., 1974, Effects of de-icing salts on the waters of the Irondequoit Bay drainage basin, Monroe County, New York: in Coogan, A.H., ed., Fourth Symposium on Salt: Cleveland, Ohio, Northern Ohio Geological Society, v. 1, p. 391-405.

Dunn, Bernard, 1962, Hydrology of the Irondequoit Creek basin, Rochester, N. Y.: U.S. Geological Survey OpenFile Report 65-046, 40 p.

Guy, H.P., 1969, Laboratory theory and methods for sediment analysis: U.S. Geological Survey Techniques of Water-Resources Investigations, book 5, chap. C1, $58 \mathrm{p}$.

Hem, J.D., 1985, Study and interpretation of chemical characteristics of natural water: U.S. Geological Survey Water-Supply Paper 2254, 264 p.

Hornlein, J.F., Szabo, C.O., and Zajd, H.J., Jr., 1995, WaterResources Data, New York, Water year 1994, volume 3-Western New York: U.S. Geological Survey Water-Data Report NY-94-3 (published annually), $326 \mathrm{p}$.

Hutchinson, G.E., 1975, A treatise on limnology, volume III, limnological botany: New York, N.Y., John Wiley and Sons, $660 \mathrm{p}$.

Johnston, W.H., and Sherwood, D.A. 1994, Water resources of Monroe County, New York, water years 1984-88, with emphasis on water quality in the Irondequoit Creek basin, part 1. Water-resources data: U.S. Geological Survey Open-File Report 93-370, 311 p. 
Kappel, W.M., Yager, R.M., and Zarriello, P.J., 1986, Quantity and quality of urban storm runoff in the Irondequoit Creek basin near Rochester, New York, Part 2Quality of storm runoff and atmospheric deposition, runoff-quality modeling, and potential of wetlands for sediment and nutrient retention: U.S. Geological Survey Water-Resources Investigations Report 85-4113, 93 p.

Kappel, W.M., and Young, R.A., 1989, Glacial history and geohydrology of the Irondequoit Creek valley, Monroe County, New York: U.S. Geological Survey WaterResources Investigations Report 88-4145, 34 p.

Kilpatrick, F.A., and Wilson, J.F., Jr., 1988, Measurement of time of travel in streams by dye tracing: U.S. Geological Survey Techniques of Water-Resources Investigations, Book 3, Chapter A9, 27 p.

Larsen, C.E., 1985, Lake level, uplift, and outlet incision, the Nipissing and Algoma Great Lakes: in Karrow, P.F., and Calkin, P.E., Quaternary evolution of the Great Lakes: Geological Association of Canada, Special Paper 30, p. 63-78.

Miller, D.J., and Ringler, N.H., 1992, Effects of storm water retention on the animal community of the upper and lower wetlands of Irondequoit Creek, Rochester, New York: Unpublished report on file in the Ithaca, N.Y., office of the U.S. Geological Survey, $50 \mathrm{p}$.

Mitsch, W.J., and Gosselink, J.G., 1986, Wetlands: New York, N.Y., Van Nostrand Reinhold, 539 p.

Monroe County Department of Health, Environmental Health Laboratory, and University of Rochester, Department of Geological Sciences, 1984, Irondequoit BayIde's Cove lake restoration (314) - diagnostic/feasibility study: draft final report, $89 \mathrm{p}$.

O'Brien and Gere, 1983, Nationwide urban runoff program, Irondequoit basin study, final report: Rochester, N.Y., Irondequoit Bay Pure Waters District, $164 \mathrm{p}$.

Peters, N.E., and Bonelli, J.E., 1982, Chemical composition of bulk precipitation in the north-central and northeastern United States, December 1980 through February 1981: U.S. Geological Survey Circular 874, 63 p.

Schroeder, R.A., 1985, Sediment accumulation rates in Irondequoit Bay, New York, based on lead-210 and cesium-137 geochronology: Northeastern Environmental Science, v. 4, no. 1, p. 23-29.

Smith, J.A., Witkowski, P.J., and Fusillo, T.V., 1988, Manmade organic compounds in the surface waters of the United States - a review of current understanding: U.S. Geological Survey Circular 1007, 92 p.

Spencer, E.W., 1972, The dynamics of the earth-an introduction to physical geology: New York, Thomas Y. Crowell, 649 p.
Timme, P.J., 1995, National Water Quality Laboratory 1995 services catalog: U.S. Geological Survey Open-file Report 95-352, 120 p.

Vitosh, M.L., Warncke, D.D., and Lucas, R.E., 1973, Secondary and micronutrients for vegetables and field crops: Extension Bulletin E-486, Cooperative Extension Service, Michigan State University, East Lansing; in Donahue, R.L., Miller, R.W., and Shickluna, J.C., 1977, Soils - an introduction to soils and plant growth: Englewood Cliffs, N.J., Prentice-Hall, 626 p.

Wershaw, R.L., Fishman, M.J., Grabbe, R.R., and Lowe, L.E. (eds.), 1987, Methods for the determination of organic substances in water and fluvial sediments: U.S. Geological Survey Techniques of Water-Resources Investigations, Book 5, Chap. A3, $80 \mathrm{p}$.

Wolman, M.G., 1954, A method of sampling coarse riverbed material: American Geophysical Union, Transactions, v. 35, no. 6, p. 951-956.

Yager, R.M., Zarriello, P.J., and Kappel, W.M., 1985, Geohydrology of the Irondequoit Creek basin near Rochester, New York: U.S. Geological Survey WaterResources Investigations Report 84-4259. 6 sheets, scale 1:24,000, .

Young, R.A., 1992, Summary report draft, Irondequoit Creek-Empire wetlands project radiocarbon dating lake level study: Unpublished report on file in the Ithaca, N.Y., office of the U.S. Geological Survey, $9 \mathrm{p}$.

Zarriello, P.J., 1996, Simulated effects of a stormwaterdetention basin on peak flows and water quality of East Branch Allen Creek, Monroe County, New York: U.S. Geological Survey Water-Resources Investigations Report 95-4157, 34 p.

Zarriello, P.J., Harding, W.E., Yager, R.M., and Kappel, W.M., 1985, Quantity and quality of storm runoff in the Irondequoit Creek basin near Rochester, New York, Part 1-Data-collection network and methods, qualityassurance program, and description of available data: U.S. Geological Survey Open-File Report 84-610, 44 p.

Zarriello, P.J., and Sherwood, D.A., 1993, Effects of stormwater detention on the chemical quality of runoff from a small residential development, Monroe County, New York: U.S. Geological Survey Water-Resources Investigations Report 92-4003, 57 p.

Zarriello, P.J., and Surface, J.M., 1989, Simulation of changes in stormwater quality at four potential flowattenuation sites in the Irondequoit Creek watershed, Monroe County, New York: U.S. Geological Survey Water-Resources Investigations Report 88-4106, 52 p. 
Table A-1. Selected analyses of surface-water samples from Irondequoit Creek at upstream and downstream ends of Ellison Park wetland, Monroe County, N.Y., for flows above median daily discharge (90 cubic feet per second), March 1991 through December 1994

[Locations are shown in fig. $2 . \mu \mathrm{S} / \mathrm{cm}$, microsiemens per centimeter; DEG. C, degrees Celsius; $\mathrm{mg} / \mathrm{L}$, milligrams per liter; $\mu \mathrm{g} / \mathrm{L}$, micrograms per liter; <, less than; --, no data.]

Part A. Irondequoit Creek above Blossom Road, Rochester, N.Y. (station 0423205010)

\begin{tabular}{|c|c|c|c|c|c|c|c|c|c|}
\hline $\begin{array}{l}\text { BEGIN } \\
\text { DATE }\end{array}$ & $\begin{array}{l}\text { BEGIN } \\
\text { TIME }\end{array}$ & $\begin{array}{l}\text { END } \\
\text { DATE }\end{array}$ & $\begin{array}{l}\text { END } \\
\text { TIME }\end{array}$ & $\begin{array}{l}\text { DIS- } \\
\text { CHARGE, } \\
\text { IN } \\
\text { CUBIC } \\
\text { FEET } \\
\text { PER } \\
\text { SECOND }\end{array}$ & $\begin{array}{c}\text { SPE- } \\
\text { CIFIC } \\
\text { CON- } \\
\text { DUCT- } \\
\text { ANCE } \\
(\mu S / \mathrm{Cm})\end{array}$ & $\begin{array}{l}\text { RES IDUE } \\
\text { TOTAL } \\
\text { AT } 105 \\
\text { DEG. C, } \\
\text { SUS- } \\
\text { PENDED } \\
\text { (mg/L) }\end{array}$ & $\begin{array}{l}\text { RESIDUE } \\
\text { VOLA- } \\
\text { TILE, } \\
\text { SUS- } \\
\text { PENDED } \\
\text { (mg/L) }\end{array}$ & $\begin{array}{c}\text { NITROGEN, } \\
\text { AMMONIA, } \\
\text { DIS- } \\
\text { SOLVED } \\
(\mathrm{mg} / \mathrm{L} \\
\text { AS N) }\end{array}$ & $\begin{array}{l}\text { NITROGEN, } \\
\text { AMMONIA + } \\
\text { ORGANIC, } \\
\text { TOTAL } \\
\text { (Mg/L } \\
\text { AS N) }\end{array}$ \\
\hline \multicolumn{10}{|l|}{1991} \\
\hline MAR 02 & 1005 & 910304 & 0305 & 440 & 890 & 926 & 91 & 0.020 & 2.6 \\
\hline MAR 07 & 1105 & 910308 & 1005 & 563 & 612 & 1,090 & 92 & 0.170 & 3.8 \\
\hline 08 & 1320 & $-\cdots$ & -- & 409 & 697 & -- & -- & 0.040 & 0.72 \\
\hline 11 & 1140 & -- & -- & 208 & 877 & -- & -- & 0.030 & 0.56 \\
\hline \multicolumn{10}{|l|}{1992} \\
\hline FEB 18 & 1020 & 920219 & 1320 & 144 & 1,280 & -- & -- & 0.030 & 0.63 \\
\hline FEB 19 & 1420 & 920220 & 0820 & 186 & 1,300 & -- & -- & 0.020 & 0.92 \\
\hline FEB 20 & 0915 & 920222 & 2015 & 160 & 1,170 & -- & -- & 0.020 & 0.95 \\
\hline FEB 22 & 2115 & 920224 & 0815 & 188 & 1,170 & -- & -- & 0.020 & 0.90 \\
\hline $\operatorname{MAR} 26$ & 0915 & 920327 & 2015 & 609 & -- & 964 & 84 & 0.020 & 2.9 \\
\hline MAR 27 & 2115 & 920330 & 0815 & 852 & $\ldots$ & 490 & 44 & 0.020 & 1.9 \\
\hline OCT 09 & 1330 & 921010 & 0430 & 299 & 708 & 227 & 38 & 0.070 & 1.6 \\
\hline OCT 10 & 0530 & 921013 & 1030 & 160 & 810 & 89 & 16 & 0.020 & 0.90 \\
\hline $\mathrm{NOV} 02$ & 1030 & 921103 & 0930 & 312 & 813 & -- & -- & $<0.010$ & 0.72 \\
\hline NOV 03 & 1030 & 921105 & 0430 & 342 & 684 & 76 & 11 & $<0.010$ & 0.88 \\
\hline DEC 10 & 1100 & 921214 & 1000 & 120 & 1,420 & 10 & $<10$ & 0.020 & 0.48 \\
\hline DEC 14 & 1205 & 921216 & 0505 & 140 & 1,230 & 14 & $<6$ & $<0.010$ & 0.46 \\
\hline DEC 16 & 0605 & 921217 & 1005 & 286 & 1.150 & 132 & 27 & $<0.010$ & 1.7 \\
\hline DEC 17 & 1100 & 921218 & 0200 & 498 & 931 & -- & -- & $<0.010$ & 1.1 \\
\hline DEC 18 & 0300 & 921221 & 1000 & 439 & 792 & -- & -- & $<0.010$ & 1.2 \\
\hline \multicolumn{10}{|l|}{1993} \\
\hline FEB 04 & 1215 & -- & -- & 147 & -- & $<7$ & $<7$ & 0.020 & 0.62 \\
\hline MAR 22 & 0920 & 930325 & 0820 & 307 & -- & 84 & 10 & 0.020 & 0.84 \\
\hline MAR 25 & 0915 & 930329 & 0815 & 721 & -- & 272 & 21 & 0.030 & 1.2 \\
\hline MAR 29 & 0925 & 930330 & 0025 & 1,270 & 575 & 369 & 23 & 0.040 & 1.1 \\
\hline DATE & $\begin{array}{c}\text { NITROGEN, } \\
\text { NO2+NO3, } \\
\text { TOTAL } \\
(\mathrm{mg} / \mathrm{L} \\
\text { AS N) }\end{array}$ & $\begin{array}{c}\text { PHOS- } \\
\text { PHORUS, } \\
\text { TOTAL } \\
\text { (mg/L } \\
\text { AS P) }\end{array}$ & $\begin{array}{l}\text { PHOS- } \\
\text { PHORUS } \\
\text { ORTHO, } \\
\text { DIS- } \\
\text { SOLVED } \\
\text { (mg/L } \\
\text { AS P) }\end{array}$ & $\begin{array}{l}\text { CHLO- } \\
\text { RIDE, } \\
\text { DIS- } \\
\text { SOLVED } \\
\text { (mg/L } \\
\text { AS Cl) }\end{array}$ & $\begin{array}{l}\text { SULFATE, } \\
\text { DIS- } \\
\text { SOLVED } \\
(\mathrm{mg} / \mathrm{L} \\
\left.\mathrm{AS} \mathrm{SO}_{4}\right)\end{array}$ & $\begin{array}{c}\text { CADMIUM, } \\
\text { TOTAL } \\
\text { RECOV- } \\
\text { ERABLE } \\
(\mu \mathrm{g} / \mathrm{L} \\
\text { AS Cd) }\end{array}$ & $\begin{array}{l}\text { COPPER, } \\
\text { TOTAL } \\
\text { RECOV- } \\
\text { ERABLE } \\
(\mu \mathrm{g} / \mathrm{L} \\
\text { AS Cu) }\end{array}$ & $\begin{array}{l}\text { LEAD, } \\
\text { TOTAL } \\
\text { RECOV- } \\
\text { ERABLE } \\
(\mu \mathrm{g} / \mathrm{L} \\
\text { AS Pb) }\end{array}$ & $\begin{array}{l}\text { ZINC, } \\
\text { TOTAL } \\
\text { RECOV- } \\
\text { ERABLE } \\
(\mu \mathrm{g} / \mathrm{L} \\
\text { AS } \mathrm{Zn})\end{array}$ \\
\hline \multicolumn{10}{|l|}{1991} \\
\hline MAR $02-04$ & 1.10 & 1.05 & 0.010 & 130 & 7.7 & 2 & 90 & 50 & 240 \\
\hline MAR 07-08 & 0.470 & 1.25 & 0.006 & 69 & 43 & 1 & 70 & 84 & 260 \\
\hline $08 \ldots$ & 1.30 & 0.090 & 0.016 & 78 & 63 & $<5$ & $<10$ & $<5$ & 40 \\
\hline $11 \ldots$ & 1.60 & 0.040 & 0.009 & 95 & 94 & $<1$ & $<10$ & 7 & $<40$ \\
\hline \multicolumn{10}{|l|}{1992} \\
\hline FEB $18-19$ & 1.40 & 0.065 & 0.008 & 230 & 120 & $<1$ & 120 & 6 & 60 \\
\hline $\mathrm{FEB} \quad 19-20$ & 1.50 & 0.120 & 0.008 & 230 & 120 & $<1$ & 50 & 20 & 40 \\
\hline FEB $20-22$ & 1.80 & 0.075 & 0.008 & 180 & 130 & $<1$ & 60 & 5 & 40 \\
\hline FEB $22-24$ & 1.80 & 0.110 & 0.007 & 120 & 140 & $<1$ & 60 & 6 & 40 \\
\hline MAR $26-27$ & 1.30 & 1.15 & 0.008 & 140 & 73 & 1 & 90 & 56 & 290 \\
\hline MAR $27-30$ & 1.60 & 0.690 & 0.012 & 110 & 58 & $<1$ & 90 & 15 & 140 \\
\hline OCT $09-10$ & 0.520 & 0.300 & 0.018 & 67 & 100 & 1 & 70 & 16 & 110 \\
\hline OCT $10-13$ & 0.450 & 0.160 & 0.009 & 74 & 110 & $<1$ & 40 & 6 & 60 \\
\hline NoV $02-03$ & 0.750 & 0.110 & 0.008 & 78 & 110 & 1 & 50 & 7 & 50 \\
\hline NOV $03-05$ & 0.530 & 0.270 & 0.012 & 60 & 75 & 3 & 100 & 10 & 40 \\
\hline DEC $10-14$ & 1.30 & 0.035 & 0.005 & 250 & 130 & $<1$ & 60 & $<5$ & $<40$ \\
\hline DEC $14-16$ & 1.20 & 0.035 & 0.005 & 180 & 120 & $<1$ & 80 & $<5$ & 40 \\
\hline DEC $16-17$ & 1.10 & 0.240 & 0.005 & 190 & 94 & $<1$ & 70 & 6 & 60 \\
\hline DEC $17-18$ & 0.960 & 0.250 & 0.007 & 140 & 58 & $<1$ & 60 & -- & 80 \\
\hline DEC $18-21$ & 1.00 & 0.200 & 0.007 & 97 & 59 & $<1$ & 50 & -- & 70 \\
\hline \multicolumn{10}{|l|}{1993} \\
\hline FEB $04 \ldots$ & 1.40 & 0.020 & 0.006 & 240 & 120 & $<1$ & $<50$ & $<5$ & $<40$ \\
\hline MAR $22-25$ & 1.60 & 0.130 & 0.005 & 210 & 81 & $<1$ & 100 & 5 & 50 \\
\hline MAR $25-29$ & 1.20 & 0.270 & 0.010 & 120 & 48 & $<1$ & 70 & 6 & 60 \\
\hline MAR $29-30$ & 1.00 & 0.340 & 0.014 & 67 & 37 & $<1$ & 120 & 20 & 80 \\
\hline
\end{tabular}


Table A-1. Selected analyses of surface-water samples from Irondequoit Creek at upstream and downstream ends of Ellison Park wetland, Monroe County, N.Y., for flows above median daily discharge (90 cubic feet per second), March 1991 through December 1994--continued

Part A. Irondequoit Creek above Blossom Road, Rochester, N.Y. (station 0423205010)-continued

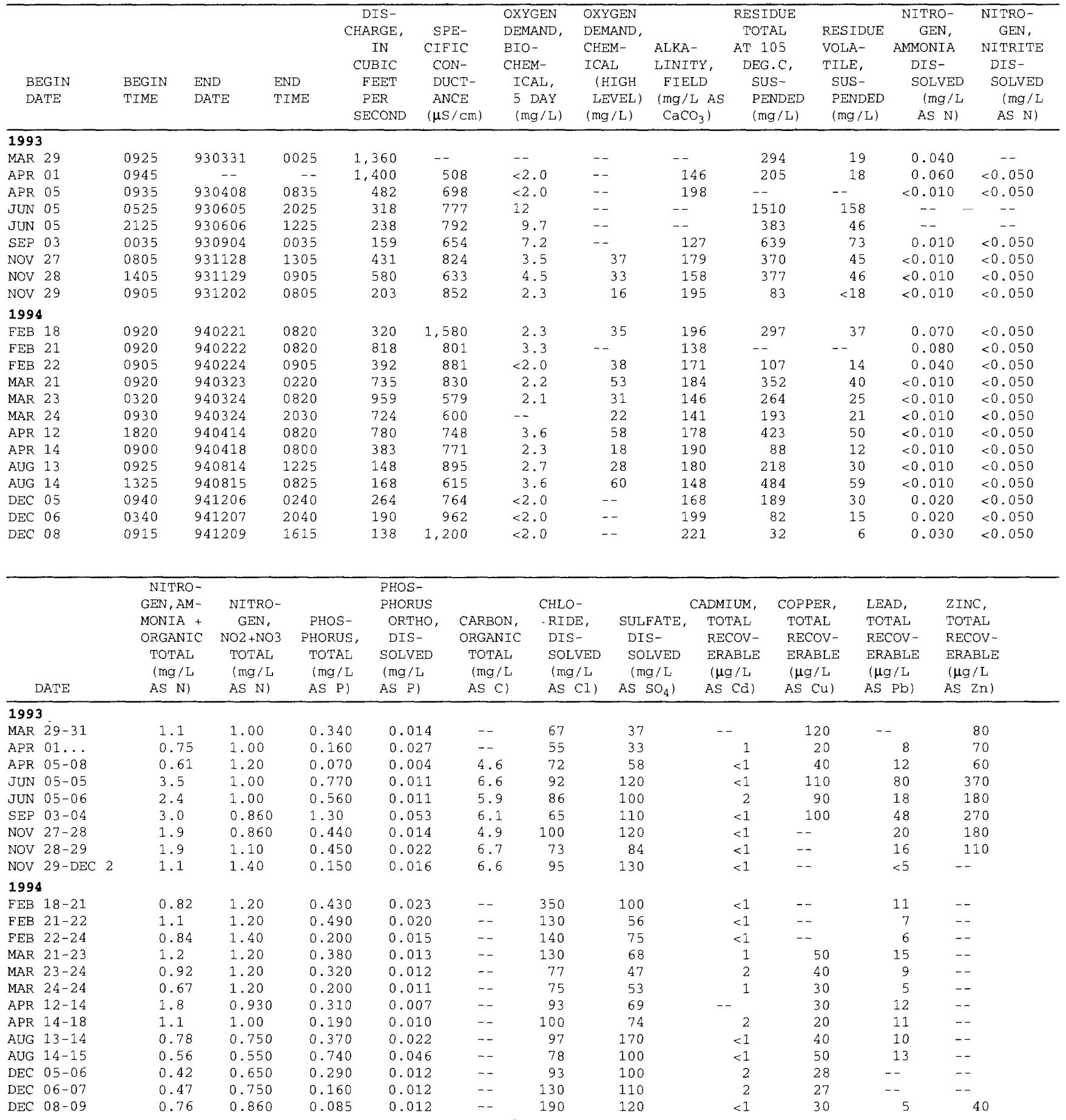


Table A-1. Selected analyses of surface-water samples from Irondequoit Creek at upstream and downstream ends of Ellison Park wetland, Monroe County, N.Y., for flows above median daily discharge (90 cubic feet per second), March 1991 through December 1994--continued

Part B. Irondequoit Creek at Empire Boulevard, Rochester, N.Y. (station 0423205025)

\begin{tabular}{|c|c|c|c|c|c|c|c|c|c|c|c|}
\hline $\begin{array}{l}\text { BEGIN } \\
\text { DATE }\end{array}$ & $\begin{array}{l}\text { BEGIN } \\
\text { TIME }\end{array}$ & $\begin{array}{l}\text { END } \\
\text { DATE }\end{array}$ & $\begin{array}{l}\text { END } \\
\text { TIME }\end{array}$ & $\begin{array}{c}\text { DIS- } \\
\text { CHARGE, } \\
\text { IN } \\
\text { CUBIC } \\
\text { FEET } \\
\text { PER } \\
\text { SECOND }\end{array}$ & $\begin{array}{l}\text { SPE- } \\
\text { CIFIC } \\
\text { CON- } \\
\text { DUCT- } \\
\text { ANCE } \\
(\mu \mathrm{S} / \mathrm{Cm})\end{array}$ & $\begin{array}{l}\text { OXYGEN } \\
\text { DEMAND, } \\
\text { BIO- } \\
\text { CHEM- } \\
\text { ICAL, } \\
5 \mathrm{DAY} \\
(\mathrm{mg} / \mathrm{L})\end{array}$ & $\begin{array}{l}\text { ALKA- } \\
\text { LINITY, } \\
\text { FIELD } \\
(\mathrm{mg} / \mathrm{L} \text { AS } \\
\left.\mathrm{CaCO}_{3}\right)\end{array}$ & $\begin{array}{l}\text { RESIDUE } \\
\text { TOTAL } \\
\text { AT } 105 \\
\text { DEG. C, } \\
\text { SUS- } \\
\text { PENDED } \\
\text { (mg/L) }\end{array}$ & $\begin{array}{l}\text { RESIDUE } \\
\text { VOLA- } \\
\text { TILE, } \\
\text { SUS- } \\
\text { PENDED } \\
(\mathrm{mg} / \mathrm{L})\end{array}$ & $\begin{array}{c}\text { NITRO- } \\
\text { GEN, } \\
\text { AMMONIA } \\
\text { DIS- } \\
\text { SOLVED } \\
\text { (mg/L } \\
\text { AS N) }\end{array}$ & $\begin{array}{c}\text { NITRO- } \\
\text { GEN, } \\
\text { NITRITE } \\
\text { DIS- } \\
\text { SOLVED } \\
\text { (mg/L } \\
\text { AS N) }\end{array}$ \\
\hline \multicolumn{12}{|l|}{1991} \\
\hline MAR 02 & 1825 & 910304 & 0925 & 438 & 832 & $\ldots$ & -- & 488 & 46 & 0.020 & -- \\
\hline MAR 06 & 1110 & 910308 & 1010 & 659 & 610 & -- & -- & 157 & 17 & 0.040 & -- \\
\hline MAR 08 & 1015 & 910311 & 0915 & 291 & 772 & -- & -- & -- & -- & 0.020 & -- \\
\hline MAR 12 & 0955 & -- & -- & 175 & -- & -- & -- & -- & -- & 0.040 & -- \\
\hline \multicolumn{12}{|l|}{1992} \\
\hline FEB 15 & 1815 & 920216 & 1715 & 136 & 1,800 & -- & -- & 28 & $<21$ & 0.090 & -- \\
\hline FEB 16 & 1815 & 920217 & 1915 & 143 & 1,400 & -- & -- & 33 & $<21$ & 0.080 & -- \\
\hline FEB 18 & 1130 & 920219 & 1430 & 136 & 1,310 & -- & $\ldots$ & -- & -- & 0.050 & -- \\
\hline FEB 19 & 1530 & 920220 & 0930 & 160 & 1,320 & -- & -- & -- & -- & 0.050 & -- \\
\hline FEB 20 & 1015 & 920222 & 2115 & 148 & 1,200 & -- & -- &.- & -- & 0.040 & $\ldots$ \\
\hline $\mathrm{FEB} \quad 22$ & 2215 & 920224 & 0915 & 176 & 1,230 & -- & -- & -- & -- & 0.040 & -- \\
\hline MAR 26 & 1000 & 920328 & 0400 & 714 & -- & -- & -- & 367 & 37 & 0.040 & -- \\
\hline MAR 28 & 0500 & 920330 & 0900 & 1,010 & -- & -- & -- & 125 & 16 & 0.040 & -- \\
\hline OCT 09 & 0945 & 921010 & 0845 & 256 & 880 & -- & -- & 104 & 19 & 0.030 & -- \\
\hline OCT 10 & 0945 & 921013 & 0845 & 167 & 785 & -- & -- & 105 & 19 & 0.020 & -- \\
\hline NOV 02 & 1010 & 921103 & 2110 & 316 & 816 & - & -- & 135 & 15 & $<0.010$ & -- \\
\hline NOV 03 & 2210 & 921105 & 0910 & 336 & 694 & -- & -- & 105 & 14 & $<0.010$ & -- \\
\hline $\mathrm{DEC} 10$ & 1025 & 921214 & 0925 & 134 & 1,460 & -- & -- & $<10$ & $<10$ & 0.020 & -- \\
\hline DEC 14 & 1125 & 921216 & 0725 & 147 & 1,300 & -- & -- & 11 & $<8$ & 0.020 & -- \\
\hline $\mathrm{DEC} 16$ & 0825 & 921217 & 0925 & 276 & 1,210 & -- & -- & 34 & 8 & 0.020 & -- \\
\hline DEC 17 & 1025 & 921218 & 0125 & 437 & 1,020 & -- & -- & -- & -- & 0.020 & -- \\
\hline DEC 18 & 0225 & 921221 & 0925 & 461 & 809 & -- & -- & -- & -- & 0.020 & -- \\
\hline \multicolumn{12}{|l|}{1993} \\
\hline FEB 01 & 1100 & 930204 & 1000 & 162 & -- & -- & -- & 10 & $<7$ & 0.020 & -- \\
\hline MAR 22 & 0950 & 930325 & 0850 & 325 & - & $\ldots$ & -- & 22 & 4 & 0.040 & -- \\
\hline MAR 25 & 0950 & 930329 & 0850 & 668 & -- & -- & -- & 77 & 7 & 0.040 & -- \\
\hline MAR 29 & 1005 & 930331 & 0405 & 1,260 & 594 & $<2.0$ & 160 & - & - & 0.050 & $<0.050$ \\
\hline MAR 29 & 1005 & 930331 & 0605 & 1,250 & 597 & $<2.0$ & 159 & 90 & 8 & 0.050 & $<0.050$ \\
\hline DATE & $\begin{array}{c}\text { NITRO- } \\
\text { GEN, AM- } \\
\text { MONIA + } \\
\text { ORGANIC } \\
\text { TOTAL } \\
(\mathrm{Mg} / \mathrm{L} \\
\text { AS N) }\end{array}$ & $\begin{array}{c}\text { NITRO- } \\
\text { GEN, } \\
\text { NO2 +NO3 } \\
\text { TOTAL } \\
(\mathrm{mg} / \mathrm{L} \\
\text { AS N) }\end{array}$ & $\begin{array}{c}\text { PHOS- } \\
\text { PHORUS } \\
\text { TOTAL } \\
\text { (mg/L } \\
\text { AS P) }\end{array}$ & $\begin{array}{c}\text { PHOS- } \\
\text { PHORUS } \\
\text { ORTHO, } \\
\text { DIS- } \\
\text { SOLVED } \\
(\mathrm{mg} / \mathrm{L} \\
\text { AS P) }\end{array}$ & $\begin{array}{c}\text { CARBON, } \\
\text { ORGANIC } \\
\text { TOTAL } \\
\text { (mg/L } \\
\text { AS C) }\end{array}$ & $\begin{array}{l}\text { CHLO- } \\
\text { RIDE, } \\
\text { DIS- } \\
\text { SOLVED } \\
(\mathrm{mg} / \mathrm{L} \\
\text { AS Cl) }\end{array}$ & $\begin{array}{l}\text { SULFATE } \\
\text { DIS- } \\
\text { SOLVED } \\
(\mathrm{mg} / \mathrm{L} \\
\left.\mathrm{AS} \mathrm{SO}_{4}\right)\end{array}$ & $\begin{array}{c}\text { CADMIUM } \\
\text { TOTAL } \\
\text { RECOV- } \\
\text { ERABLE } \\
(\mu \mathrm{g} / \mathrm{L} \\
\text { AS Cd) }\end{array}$ & $\begin{array}{c}\text { COPPER, } \\
\text { TOTAL } \\
\text { RECOV- } \\
\text { ERABLE } \\
(\mu \mathrm{g} / \mathrm{L} \\
\mathrm{AS} \mathrm{Cu})\end{array}$ & $\begin{array}{l}\text { LEAD, } \\
\text { TOTAL } \\
\text { RECOV- } \\
\text { ERABLE } \\
(\mu \mathrm{g} / \mathrm{L} \\
\mathrm{AS} \mathrm{Pb})\end{array}$ & $\begin{array}{l}\text { ZINC, } \\
\text { TOTAL } \\
\text { RECOV- } \\
\text { ERABLE } \\
(\mu \mathrm{g} / \mathrm{L} \\
\mathrm{AS} \mathrm{Zn)}\end{array}$ \\
\hline \multicolumn{12}{|l|}{1991} \\
\hline MAR $02-04$ & 1.7 & 1.00 & 0.490 & 0.014 & -- & 130 & 66 & 1 & 80 & 39 & 150 \\
\hline MAR $06-08$ & 0.87 & 1.10 & 0.240 & 0.015 & -- & 71 & 49 & $<1$ & 70 & 13 & 90 \\
\hline MAR 08-11 & 0.79 & 1.50 & 0.110 & 0.013 & -- & 93 & 71 & $<1$ & 50 & 8 & 60 \\
\hline MAR 12 & 0.61 & 1.40 & 0.030 & 0.009 & -- & 100 & 100 & $<1$ & $<10$ & $<5$ & $<40$ \\
\hline \multicolumn{12}{|l|}{1992} \\
\hline FEB $15-16$ & 0.70 & 1.30 & 0.075 & 0.008 & -- & 390 & 240 & $<1$ & 70 & 6 & -- \\
\hline $\mathrm{FEB} 16-17$ & 0.77 & 1.30 & 0.085 & 0.009 & - - & 280 & 130 & $<1$ & 70 & $<5$ & -- \\
\hline FEB $18-19$ & 0.77 & 1.50 & 0.085 & 0.008 & -- & 240 & 120 & $<1$ & 70 & 7 & -- \\
\hline FEB $19-20$ & 0.86 & 1.50 & 0.095 & 0.009 & -- & 230 & 120 & $<1$ & 70 & 7 & -- \\
\hline FEB 20-22 & 0.64 & 1.70 & 0.060 & 0.009 & -- & 190 & 140 & $<1$ & 60 & 5 & $<40$ \\
\hline FEB $\quad 22-24$ & 0.73 & 1.70 & 0.065 & 0.009 & -- & 200 & 140 & $<1$ & 50 & $<5$ & $<40$ \\
\hline MAR 26-28 & 1.8 & 1.30 & 0.460 & 0.008 & -- & 140 & 66 & 1 & 90 & 37 & 120 \\
\hline MAR 28-30 & 1.2 & 1.60 & 0.200 & 0.016 & -- & 120 & 56 & 1 & $<50$ & 14 & 90 \\
\hline OCT $09-10$ & 0.94 & 1.00 & 0.190 & 0.024 & -- & 87 & 130 & $<\overline{1}$ & 40 & 8 & 70 \\
\hline OCT $10-13$ & 0.94 & 0.670 & 0.200 & 0.027 & -- & 74 & 100 & $<1$ & 40 & 6 & 60 \\
\hline NOV $02-03$ & 1.1 & 0.870 & 0.310 & 0.026 & -- & 79 & 110 & 1 & 40 & 9 & 70 \\
\hline NOV $03-05$ & 1.0 & 0.570 & 0.190 & 0.026 & -- & 61 & 73 & 1 & 40 & 7 & 70 \\
\hline DEC 10-14 & 0.56 & 1.40 & 0.050 & 0.014 & -- & 250 & 130 & $<1$ & 60 & $<5$ & 40 \\
\hline DEC $14-16$ & 0.60 & 1.30 & 0.050 & 0.014 & $\ldots$ & 200 & 120 & $<1$ & 80 & $<5$ & 30 \\
\hline DEC $16-17$ & 0.69 & 1.20 & 0.085 & 0.014 & -- & 200 & 96 & $<1$ & 90 & $<5$ & 50 \\
\hline DEC $17-18$ & 0.81 & 1.00 & 0.120 & 0.019 & -- & 160 & 61 & $<1$ & 70 & -- & 110 \\
\hline DEC $18-21$ & 0.69 & 1.00 & 0.120 & 0.021 & -- & 100 & 55 & $<1$ & 70 & -- & 80 \\
\hline \multicolumn{12}{|l|}{1993} \\
\hline FEB $01-04$ & 0.66 & 1.50 & 0.045 & 0.009 & -- & 230 & 120 & $<1$ & $<50$ & 8 & $<40$ \\
\hline MAR 22-25 & 0.60 & 1.20 & 0.055 & 0.011 & -- & 230 & 84 & $<1$ & 70 & $<5$ & 40 \\
\hline MAR 25-29 & 0.77 & 1.20 & 0.120 & 0.016 & -- & 130 & 50 & $<1$ & 90 & $<5$ & 110 \\
\hline MAR 29-31 & 0.76 & 1.00 & 0.170 & 0.021 & -- & 72 & 37 & $<1$ & 100 & 6 & 70 \\
\hline MAR 29-31 & 0.76 & 1.00 & 0.160 & 0.021 & -- & 73 & 37 & $<1$ & 80 & 7 & 50 \\
\hline
\end{tabular}


Table A-1. Selected analyses of surface-water samples from Irondequoit Creek at upstream and downstream ends of Ellison Park wetland, Monroe County, N.Y., for flows above median daily discharge ( 90 cubic feet per second), March 1991 through December 1994--continued

Part B. Irondequoit Creek at Empire Boulevard, Rochester, N.Y. (station 0423205025)--continued

\begin{tabular}{|c|c|c|c|c|c|c|c|c|c|c|c|c|}
\hline $\begin{array}{l}\text { BEGIN } \\
\text { DATE }\end{array}$ & $\begin{array}{l}\text { BEGIN } \\
\text { TIME }\end{array}$ & $\begin{array}{l}\text { ENDING } \\
\text { DATE }\end{array}$ & $\begin{array}{l}\text { ENDING } \\
\text { TIME }\end{array}$ & $\begin{array}{c}\text { DIS- } \\
\text { CHARGE, } \\
\text { IN } \\
\text { CUBIC } \\
\text { FEET } \\
\text { PER } \\
\text { SECOND }\end{array}$ & $\begin{array}{l}\text { SPE- } \\
\text { CIFIC } \\
\text { CON- } \\
\text { DUCT- } \\
\text { ANCE } \\
(\mu \mathrm{S} / \mathrm{Cm})\end{array}$ & $\begin{array}{l}\text { OXYGEN } \\
\text { DEMAND, } \\
\text { BIO- } \\
\text { CHEM- } \\
\text { ICAL, } \\
5 \text { DAY } \\
\text { (mg/L) }\end{array}$ & $\begin{array}{l}\text { OXYGEN } \\
\text { DEMAND, } \\
\text { CHEM- } \\
\text { ICAL } \\
\text { (HIGH } \\
\text { LEVEL) } \\
(\mathrm{mg} / \mathrm{L})\end{array}$ & $\begin{array}{l}\text { ALKA- } \\
\text { LINITY, } \\
\text { FIELD } \\
(\mathrm{mg} / \mathrm{L} \text { AS } \\
\left.\mathrm{CaCO}_{3}\right)\end{array}$ & $\begin{array}{l}\text { RESIDUE } \\
\text { TOTAL } \\
\text { AT } 105 \\
\text { DEG. C, } \\
\text { SUS- } \\
\text { PENDED } \\
\text { (mg/L) }\end{array}$ & $\begin{array}{l}\text { RESIDUE } \\
\text { VOLA- } \\
\text { TILE, } \\
\text { SUS- } \\
\text { PENDED } \\
(m g / L)\end{array}$ & $\begin{array}{c}\text { NITRO- } \\
\text { GEN, } \\
\text { AMMONIA } \\
\text { DIS- } \\
\text { SOLVED } \\
\text { (Mg/L } \\
\text { AS N) }\end{array}$ & $\begin{array}{c}\text { NITRO- } \\
\text { GEN, } \\
\text { NITRITE } \\
\text { DIS- } \\
\text { SOLVED } \\
\text { (mg/L } \\
\text { AS N) }\end{array}$ \\
\hline \multicolumn{13}{|l|}{1993} \\
\hline MAR 31 & 0705 & 930401 & 0905 & 1,360 & 516 & $<2.0$ & -- & 147 & 71 & 7 & 0.030 & $<0.050$ \\
\hline APR 01 & 1030 & 930403 & 0130 & 1,760 & 483 & $<2.0$ & -- & 147 & -- & -- & 0.030 & $<0.050$ \\
\hline APR 03 & 0230 & 930405 & 0830 & 1,150 & 526 & $<2.0$ & -- & 151 & -- & -- & 0.020 & $<0.050$ \\
\hline APR 06 & 1015 & 930406 & 1045 & 496 & 698 & $<2.0$ & -- & 197 & -- & -- & 0.020 & $<0.050$ \\
\hline APR 06 & 1045 & 930408 & 0945 & 442 & 701 & $<2.0$ & -- & 196 & -- & -- & 0.020 & $<0.050$ \\
\hline JUN 05 & 0545 & 930506 & 0045 & 275 & 939 & 2.2 & -- & -- & 63 & $<10$ & -- & -- \\
\hline JUN 06 & 0145 & 930607 & 0845 & 174 & 764 & 5.3 & -- & -- & 68 & $<12$ & -- & -- \\
\hline SEP 02 & 2015 & 930904 & 0615 & 150 & 735 & $<2.0$ & -- & 140 & 54 & 10 & 0.050 & $<0.050$ \\
\hline SEP 04 & 0715 & 930907 & 0915 & 106 & 790 & $<2.0$ & -- & 155 & 50 & 28 & 0.060 & $<0.050$ \\
\hline NOV 27 & 1330 & 931128 & 1330 & 307 & 836 & $<4.0$ & 27 & 186 & 209 & 29 & 0.060 & $<0.050$ \\
\hline NOV 28 & 1430 & 931129 & 0930 & 591 & 589 & $<4.0$ & 28 & 144 & 229 & 29 & 0.040 & $<0.050$ \\
\hline NOV 29 & 1000 & 931202 & 0900 & 244 & 835 & 2.3 & 14 & 191 & 50 & $<14$ & 0.040 & $<0.050$ \\
\hline \multicolumn{13}{|l|}{1994} \\
\hline $\mathrm{FEB} \quad 18$ & 1025 & 940221 & 1325 & 362 & 1,550 & 4.9 & 29 & 186 & -- & -- & 0.090 & $<0.050$ \\
\hline FEB 21 & 1425 & 940222 & 0925 & 976 & 827 & 2.9 & 29 & 126 & 117 & 18 & 0.090 & $<0.050$ \\
\hline FEB 22 & 0945 & 940224 & 0845 & 574 & 871 & $<2.0$ & 38 & 162 & -- & -- & 0.070 & $<0.050$ \\
\hline MAR 21 & 0950 & 940323 & 0550 & 582 & 818 & 2.6 & 46 & 159 & 263 & 31. & $<0.010$ & $<0.050$ \\
\hline MAR 23 & 0650 & 940324 & 0850 & 919 & 591 & 2.2 & 21 & 131 & 272 & 28 & 0.030 & $<0.050$ \\
\hline MAR 24 & 1000 & 940327 & 0500 & 580 & 676 & -- & 20 & 159 & -- & -- & $<0.010$ & $<0.050$ \\
\hline APR 12 & 1555 & 940414 & 0855 & 563 & 777 & 2.5 & 21 & 178 & 163 & 15 & 0.020 & $<0.050$ \\
\hline APR 14 & 0930 & 940418 & 0830 & 438 & 803 & 2.7 & 22 & 191 & -- & -- & 0.010 & $<0.050$ \\
\hline AUG 13 & 0955 & 940814 & 1655 & 133 & 960 & $<2.0$ & 10 & 183 & 46 & 5 & 0.020 & $<0.050$ \\
\hline AUG 14 & 1755 & 940815 & 0855 & 180 & 593 & $<2.0$ & 22 & 120 & 86 & 11 & 0.030 & $<0.050$ \\
\hline DEC 05 & 1005 & 941206 & 0305 & 259 & 832 & $<2.0$ & -- & 182 & 116 & 19 & 0.050 & $<0.050$ \\
\hline DEC 06 & 0405 & 941208 & 0905 & 192 & 1,000 & $<2.0$ & -- & 196 & 40 & $<16$ & 0.050 & $<0.050$ \\
\hline DEC 08 & 0945 & 941209 & 2045 & 135 & 1.250 & 2.0 & -- & 216 & 18 & $<3$ & 0.050 & $<0.050$ \\
\hline
\end{tabular}

\begin{tabular}{|c|c|c|c|c|c|c|c|c|c|c|c|c|}
\hline & DATE & $\begin{array}{l}\text { NITRO- } \\
\text { GEN, AM- } \\
\text { MONIA + } \\
\text { ORGANIC } \\
\text { TOTAL } \\
(\text { Mg/L } \\
\text { AS N) }\end{array}$ & $\begin{array}{c}\text { NITRO- } \\
\text { GEN, } \\
\text { NO2 +NO3 } \\
\text { TOTAL } \\
\text { (mg / L } \\
\text { AS N) }\end{array}$ & $\begin{array}{c}\text { PHOS- } \\
\text { PHORUS } \\
\text { TOTAL } \\
\text { (mg/L } \\
\text { AS P) }\end{array}$ & $\begin{array}{c}\text { PHOS- } \\
\text { PHORUS } \\
\text { ORTHO, } \\
\text { DIS- } \\
\text { SOLVED } \\
\text { (mg/L } \\
\text { AS P) }\end{array}$ & $\begin{array}{c}\text { CARBON, } \\
\text { ORGANIC } \\
\text { TOTAL } \\
(\mathrm{mg} / \mathrm{L} \\
\text { AS C) }\end{array}$ & $\begin{array}{l}\text { CHLO- } \\
\text { RIDE, } \\
\text { DIS- } \\
\text { SOLVED } \\
\text { (mg/L } \\
\text { AS Cl) }\end{array}$ & $\begin{array}{c}\text { SULFATE } \\
\text { DIS- } \\
\text { SOLVED } \\
(\mathrm{mg} / \mathrm{L} \\
\left.\mathrm{AS} \mathrm{SO}_{4}\right)\end{array}$ & $\begin{array}{c}\text { CADMIUM } \\
\text { TOTAL } \\
\text { RECOV- } \\
\text { ERABLE } \\
(\mu \mathrm{g} / \mathrm{L} \\
\text { AS Cd) }\end{array}$ & $\begin{array}{c}\text { COPPER, } \\
\text { TOTAL } \\
\text { RECOV- } \\
\text { ERABLE } \\
(\mu \mathrm{g} / \mathrm{L} \\
\mathrm{AS} \mathrm{Cu})\end{array}$ & $\begin{array}{l}\text { LEAD, } \\
\text { TOTAL } \\
\text { RECOV- } \\
\text { ERABLE } \\
(\mu \mathrm{g} / \mathrm{L} \\
\mathrm{AS} \mathrm{Pb})\end{array}$ & $\begin{array}{l}\text { ZINC, } \\
\text { TOTAL } \\
\text { RECOV- } \\
\text { ERABLE } \\
\text { ( } \mu \mathrm{g} / \mathrm{L} \\
\text { AS Zn) }\end{array}$ \\
\hline \multicolumn{13}{|c|}{1993} \\
\hline MAR & 31-APR 01 & 0.66 & 1.00 & 0.120 & 0.020 & -- & 57 & 34 & $<1$ & 70 & 10 & 60 \\
\hline APR & $01-03$ & 0.68 & 0.970 & 0.120 & 0.023 & 5.0 & 55 & 31 & $<1$ & 90 & 10 & 70 \\
\hline APR & $03-05$ & 0.55 & 1.10 & 0.085 & 0.022 & 4.4 & 56 & 37 & $<1$ & 90 & 5 & 60 \\
\hline APR & $06-06$ & 0.65 & 1.30 & 0.075 & 0.014 & 4.4 & 74 & 59 & $<1$ & 70 & 5 & 70 \\
\hline APR & $06-08$ & 0.56 & 1.20 & 0.080 & 0.014 & 4.3 & 73 & 59 & $<1$ & 80 & 8 & 70 \\
\hline JUN & $05-06$ & 1.1 & 0.870 & 0.160 & 0.017 & 6.5 & 99 & 140 & -- & 60 & 9 & 110 \\
\hline JUN & $06-07$ & 0.91 & 0.825 & 0.145 & 0.020 & 5.6 & 89 & 100 & $<1$ & 60 & 12 & 90 \\
\hline SEP & $02-04$ & 0.76 & 0.860 & 0.140 & 0.030 & 4.3 & 74 & 130 & $<1$ & 30 & 6 & 80 \\
\hline SEP & $04-07$ & 0.78 & 0.760 & 0.060 & 0.034 & 4.5 & 85 & 120 & $<1$ & 40 & 12 & 60 \\
\hline NOV & $27-28$ & 1.6 & 0.820 & 0.190 & 0.016 & 5.0 & 100 & 110 & $<1$ & -- & 13 & 60 \\
\hline NOV & $28-29$ & 1.5 & 0.940 & 0.310 & 0.024 & 7.4 & 64 & 70 & $<1$ & -- & 11 & 80 \\
\hline NOV & $29-\mathrm{DEC} 2$ & 0.96 & 1.10 & 0.110 & 0.018 & 6.7 & 93 & 100 & $<1$ & -- & $<5$ & -- \\
\hline \multicolumn{13}{|c|}{1994} \\
\hline FEB & $18-21$ & 0.84 & 1.20 & 0.170 & 0.024 & -- & 310 & 110 & $<1$ & -- & 9 & -- \\
\hline FEB & $21-22$ & 0.69 & 1.20 & 0.190 & 0.020 & -- & 170 & 66 & $<1$ & -- & 6 & -- \\
\hline $\mathrm{FEB}$ & $22-24$ & 0.68 & 1.30 & 0.140 & 0.019 & -- & 150 & 74 & $<1$ & -- & 5 & -- \\
\hline MAR & $21-23$ & 0.99 & 1.10 & 0.280 & 0.016 & -- & 110 & 65 & 1 & 40 & 12 & -- \\
\hline MAR & $23-24$ & 0.73 & 1.10 & 0.230 & 0.018 & $-\cdots$ & 72 & 48 & 1 & 30 & 7 & -- \\
\hline MAR & $24-27$ & 0.82 & 1.10 & 0.130 & 0.016 & -- & 82 & 62 & 1 & 30 & 5 & -- \\
\hline APR & $12-14$ & 0.84 & 0.860 & -- & 0.011 & -- & 96 & 71 & -- & 20 & 8 & -- \\
\hline APR & $14-18$ & 1.5 & 0.890 & 0.170 & 0.009 & -- & 100 & 72 & $<1$ & 30 & -- & -- \\
\hline AUG & $13-14$ & 0.50 & 0.640 & 0.100 & 0.021 & -- & 110 & 170 & $<1$ & 30 & 10 & -- \\
\hline AUG & $14-15$ & 0.43 & 0.550 & 0.180 & 0.028 & -- & 69 & 91 & $<1$ & 40 & 5 & -- \\
\hline $\mathrm{DEC}$ & $05-06$ & 0.43 & 0.690 & 0.210 & 0.015 & -- & 99 & 110 & 1 & 21 & -- & -- \\
\hline DEC & $06-08$ & 0.50 & 0.740 & 0.110 & 0.015 & -- & 140 & 110 & $<1$ & 22 & -- & -- \\
\hline $\mathrm{DEC}$ & 08-09 & 0.80 & 0.840 & 0.055 & 0.012 & -- & 210 & 120 & $<1$ & 40 & $<5$ & $<40$ \\
\hline
\end{tabular}


Table A-2. Analyses of ground-water samples from observation wells in vicinity of the Ellison Park wetland, Monroe County, N.Y., December 1989 through April 1994

[Well locations are shown in fig. $2 . \mu \mathrm{S} / \mathrm{cm}$, microsiemens per centimeter; $\mathrm{mg} / \mathrm{L}$, milligrams per liter; $\mu \mathrm{g} / \mathrm{L}$, micrograms per liter; <, less than;--, no data.]

\begin{tabular}{|c|c|c|c|c|c|c|c|c|c|c|}
\hline $\begin{array}{l}\text { STATION NUMBER } \\
\text { AND } \\
\text { LOCAL WELL } \\
\text { NUMBER }\end{array}$ & DATE & $\begin{array}{l}\text { TUR- } \\
\text { BID- } \\
\text { ITY } \\
\text { (UNITS) }\end{array}$ & $\begin{array}{l}\text { COLOR } \\
\text { (PLAT- } \\
\text { INUM- } \\
\text { COBALT } \\
\text { UNITS) }\end{array}$ & $\begin{array}{l}\text { SPE- } \\
\text { CIFIC } \\
\text { CON- } \\
\text { DUCT- } \\
\text { ANCE } \\
(\mu S / C m)\end{array}$ & $\begin{array}{l}\text { OXYGEN, } \\
\text { DIS- } \\
\text { SOLVED } \\
(\mathrm{mg} / \mathrm{L})\end{array}$ & $\begin{array}{c}\mathrm{pH} \\
\text { WATER } \\
\text { WHOLE } \\
\text { LAB } \\
\text { (STAND- } \\
\text { ARD } \\
\text { UNITS) }\end{array}$ & $\begin{array}{c}\text { ALKA } \\
\text { LINITY, } \\
\text { CARBON- } \\
\text { ATE } \\
(\mathrm{mg} / \mathrm{L} \\
\left.\mathrm{CaCO}_{3}\right)\end{array}$ & $\begin{array}{l}\text { NITRO- } \\
\text { GEN, } \\
\text { AMMONIA } \\
\text { DIS- } \\
\text { SOLVED } \\
\text { (mg/L } \\
\text { AS N) }\end{array}$ & $\begin{array}{l}\text { NITRO- } \\
\text { GEN, AM- } \\
\text { MONIA + } \\
\text { ORGANIC, } \\
\text { TOTAL } \\
\text { (mg/L } \\
\text { AS N) }\end{array}$ & $\begin{array}{l}\text { NITRO- } \\
\text { GEN, } \\
\text { NO2 + NO3, } \\
\text { TOTAL } \\
\text { (mg/L } \\
\text { AS N) }\end{array}$ \\
\hline \multirow{17}{*}{$\begin{array}{c}430854077304601 \\
\text { Mo3 }\end{array}$} & $12-05-89$ & 0.95 & 5 & 1,320 & 1.1 & 7.6 & 250 & $<0.010$ & 0.16 & 0.460 \\
\hline & $03-20-90$ & 0.70 & 5 & 1,300 & 0.7 & 7.6 & 250 & $<0.010$ & 0.22 & 0.050 \\
\hline & $06-07-90$ & 0.70 & 5 & 1,310 & 2.3 & 7.6 & 240 & $<0.010$ & 0.32 & 0.520 \\
\hline & $09-26-90$ & 1.3 & 5 & 1,330 & 0.6 & 7. & 240 & $<0.010$ & $<0.10$ & 0.550 \\
\hline & $01-09-91$ & 0.95 & 5 & 1,300 & 0.3 & 7. & 250 & 0.010 & 0.22 & 0.300 \\
\hline & $04-03-91$ & 0.55 & 5 & 1,300 & 0.3 & 7 & 240 & $<0.010$ & 0.26 & 0.330 \\
\hline & $06-12-91$ & 0.85 & 5 & 1,300 & 1.2 & 7.6 & 240 & $<0.010$ & 0.77 & 0.590 \\
\hline & $09-11-91$ & 0.85 & 5 & 1,300 & 0.9 & 7.6 & 240 & $<0.010$ & 0.30 & 0.470 \\
\hline & $12-18-91$ & 0.80 & 5 & 1,290 & 6.8 & 7.5 & 240 & $<0.010$ & 0.37 & 0.330 \\
\hline & $03-18-92$ & 1.7 & 5 & 1,290 & 1.2 & 7.6 & 240 & $<0.010$ & 0.17 & 0.260 \\
\hline & $06-24-92$ & 0.75 & 5 & 1,320 & 2.2 & 7.5 & 240 & $<0.010$ & 0.45 & 0.490 \\
\hline & $09-10-92$ & 1.0 & 5 & 1,320 & 1.4 & 7.6 & 240 & $<0.010$ & 0.14 & 0.520 \\
\hline & $12-08-92$ & 1.1 & 5 & 1,300 & 0.5 & 7.4 & 240 & $<0.010$ & 0.13 & 0.450 \\
\hline & $03-09-93$ & 1.2 & 5 & 1,280 & 1.2 & 7.6 & 240 & $<0.010$ & 0.16 & 0.390 \\
\hline & $06-22-93$ & 0.60 & 5 & 1,270 & 0.6 & 7.8 & 240 & $<0.010$ & 0.29 & 0.454 \\
\hline & $09-16-93$ & 0.90 & 5 & 1,280 & 0.5 & 7.7 & 240 & $<0.010$ & 0.49 & 0.510 \\
\hline & $04-06-94$ & 0.55 & 5 & 1,280 & 0.5 & 7.5 & 240 & $<0.010$ & 0.46 & 0.320 \\
\hline \multirow{17}{*}{$\begin{array}{c}430855077304202 \\
\text { Mo2 }\end{array}$} & $12-05-89$ & 5.4 & 5 & 916 & 0.2 & 7.7 & 200 & 0.030 & 0.24 & $<0.010$ \\
\hline & $03-20-90$ & 16 & 5 & 807 & 0.4 & 7.8 & 180 & 0.030 & 0.29 & $<0.010$ \\
\hline & $06-07-90$ & 21 & 5 & 880 & 0.2 & 7.7 & 190 & 0.015 & 0.23 & 0.025 \\
\hline & $09-26-90$ & 11 & 5 & 916 & $<0.1$ & 7.8 & 190 & 0.030 & 0.13 & 0.010 \\
\hline & $01-09-91$ & 6.1 & 5 & 810 & 0.6 & 7.5 & 180 & 0.055 & 0.28 & 0.015 \\
\hline & $04-03-91$ & 5.9 & 5 & 807 & 1 & 7.6 & 180 & 0.030 & 0.17 & -- \\
\hline & $06-12-91$ & 3.6 & 5 & 897 & 0.8 & 7.7 & 190 & $<0.010$ & 0.46 & 0.120 \\
\hline & $09-11-91$ & 6.5 & 5 & 864 & 20.4 & 7.8 & 180 & 0.040 & 0.33 & 0.055 \\
\hline & $12-18-91$ & 4.6 & 5 & 1,060 & 14.4 & 7.5 & 180 & 0.055 & 0.28 & $<0.050$ \\
\hline & $03-18-92$ & 4.9 & 5 & 859 & 2.8 & 7.8 & 170 & 0.030 & 0.17 & $<0.050$ \\
\hline & $06-24-92$ & 7.3 & 5 & 933 & 0.2 & 7.6 & 180 & 0.040 & 0.54 & $<0.050$ \\
\hline & $09-10-92$ & 14 & 5 & 898 & $<0.1$ & 7.6 & 180 & 0.040 & 0.13 & $<0.050$ \\
\hline & $12-08-92$ & 5.8 & 5 & 875 & 0.7 & 7.4 & 180 & 0.040 & 0.17 & $<0.050$ \\
\hline & $03-09-93$ & 14 & 5 & 897 & 1.4 & 7.5 & 180 & 0.020 & 0.20 & 0.050 \\
\hline & $06-22-93$ & 9.4 & 5 & 907 & 0.0 & 7.8 & 180 & 0.030 & 0.32 & $<0.050$ \\
\hline & $09-16-93$ & 7.6 & 5 & 887 & $<0.1$ & 7.8 & 170 & 0.040 & 0.43 & $<0.050$ \\
\hline & $04-06-94$ & 1.1 & 6 & 888 & 1.6 & 7.6 & 170 & $<0.010$ & 0.45 & 0.050 \\
\hline \multirow{12}{*}{$\begin{array}{c}430912077313301 \\
\text { Mo663 }\end{array}$} & $04-03-91$ & 190 & 40 & 1,600 & 1.5 & 6.8 & 650 & 0.630 & 2.0 & 0.010 \\
\hline & $06-12-91$ & 160 & 80 & 1,560 & -- & 6.9 & 620 & 0.700 & 2.8 & 0.100 \\
\hline & $09-11-91$ & 60 & 35 & 1,660 & -- & 7.1 & 560 & 0.960 & -- & $<0.050$ \\
\hline & $12-18-91$ & 290 & 35 & 1,680 & -- & 7.1 & 470 & 0.650 & 1.8 & $<0.050$ \\
\hline & $03-18-92$ & 130 & 40 & 1,620 & 0.1 & 6.9 & 600 & 0.670 & 1.5 & $<0.050$ \\
\hline & $06-24-92$ & 150 & 33 & 1,600 & $<0.1$ & 7.0 & 610 & 0.800 & 2.1 & $<0.050$ \\
\hline & $09-09-92$ & 130 & 30 & 1,610 & -- & 6.9 & 600 & 1.00 & 1.8 & $<0.050$ \\
\hline & $12-08-92$ & 120 & 47 & 1,680 & 0.1 & 7.0 & 600 & 0.890 & 1.6 & $<0.050$ \\
\hline & $03-09-93$ & 150 & 30 & 1,590 & $<0.1$ & 7.0 & 600 & 0.750 & 1.7 & $<0.050$ \\
\hline & $06-22-93$ & 100 & 22 & 1,510 & -- & 7.1 & 590 & 0.800 & 1.9 & $<0.050$ \\
\hline & $09-16-93$ & 130 & 30 & 1,630 & $<0.1$ & 7.0 & 540 & 0.890 & 2.1 & $<0.050$ \\
\hline & $04-06-94$ & 90 & 30 & 1,610 & $<0.1$ & 6.9 & 610 & 0.220 & 5.2 & $<0.050$ \\
\hline \multirow{13}{*}{$\begin{array}{c}430912077313302 \\
\text { Mo664 }\end{array}$} & $01-09-91$ & 110 & 23 & 18,100 & $<0.1$ & 6.5 & 160 & 2.80 & 3.1 & 0.020 \\
\hline & $04-03-91$ & 160 & 38 & 19,700 & $<0.1$ & 6.8 & 160 & 2.90 & 3.6 & -- \\
\hline & $06-12-91$ & 160 & 110 & 17,800 & 0.6 & 6.6 & 140 & 4.10 & 15 & 0.100 \\
\hline & $09-11-91$ & 180 & 40 & 21,400 & 0.6 & 6.7 & 150 & 2.50 & -- & 0.060 \\
\hline & $12-18-91$ & 340 & 20 & 19,300 & 0.1 & 6.6 & 150 & 3.20 & 6.7 & $<0.050$ \\
\hline & $03-18-92$ & 80 & 50 & 16,900 & $<0.1$ & 6.8 & 170 & 2.50 & 5.3 & $<0.050$ \\
\hline & $06-24-92$ & 120 & 10 & 20,600 & $<0.1$ & 6.8 & 160 & 3.10 & 9.7 & 0.560 \\
\hline & $09-09-92$ & 55 & 40 & 21,200 & $<0.1$ & 6.7 & 130 & 3.50 & 5.0 & $<0.050$ \\
\hline & $12-08-92$ & 36 & 60 & 21,200 & $<0.1$ & 6.8 & 170 & 2.90 & 5.1 & $<0.050$ \\
\hline & $03-09-93$ & 60 & 20 & 21,600 & $<0.1$ & 6.9 & 140 & 3.30 & 4.8 & $<0.050$ \\
\hline & $06-22-93$ & 35 & 12 & 22,000 & 0.1 & 6.8 & 140 & 3.20 & 4.0 & $<0.050$ \\
\hline & $09-16-93$ & 70 & 15 & 23,100 & $<0.1$ & 6.6 & 120 & 3.60 & 6.4 & $<0.050$ \\
\hline & $04-06-94$ & 32 & 31 & 19,600 & $<0.1$ & 6.8 & 180 & 2.30 & 3.1 & $<0.050$ \\
\hline
\end{tabular}


Table A-2. Analyses of ground-water samples from observation wells in vicinity of the Ellison Park wetland, Monroe County, N.Y., December 1989 through April 1994--continued

[Well locations are shown in fig. 2. $\mu \mathrm{S} / \mathrm{cm}$, microsiemens per centimeter; $\mathrm{mg} / \mathrm{L}$, milligrams per liter; $\mu \mathrm{g} / \mathrm{L}$, micrograms per liter; $<$, less than;--, no data.]

\begin{tabular}{|c|c|c|c|c|c|c|c|c|c|c|c|c|c|}
\hline $\begin{array}{l}\text { LOCAL } \\
\text { WELL } \\
\text { NUM- } \\
\text { BER }\end{array}$ & DATE & $\begin{array}{l}\text { PHOS- } \\
\text { PHORUS } \\
\text { TOTAL } \\
(\mathrm{mg} / \mathrm{L} \\
\text { AS P) }\end{array}$ & $\begin{array}{c}\text { PHOS- } \\
\text { PHORUS } \\
\text { ORTHO, } \\
\text { DIS- } \\
\text { SOLVED } \\
\text { (mg/L } \\
\text { AS P) }\end{array}$ & $\begin{array}{l}\text { HARD- } \\
\text { NESS, } \\
\text { TOTAL } \\
(\mathrm{mg} / \mathrm{L} \\
\mathrm{AS} \\
\left.\mathrm{CaCO}_{3}\right)\end{array}$ & $\begin{array}{l}\text { CALCIUM, } \\
\text { TOTAL } \\
\text { RECOV- } \\
\text { ERABLE } \\
\text { (mg/L } \\
\text { AS Ca) }\end{array}$ & $\begin{array}{c}\text { MAGNE- } \\
\text { SIUM, } \\
\text { DIS- } \\
\text { SOLVED } \\
\text { (mg/L } \\
\text { AS Mg) }\end{array}$ & $\begin{array}{c}\text { SODIUM, } \\
\text { DIS- } \\
\text { SOLVED } \\
(\mathrm{mg} / \mathrm{L} \\
\text { AS Na) }\end{array}$ & $\begin{array}{l}\text { POTAS- } \\
\text { SIUM, } \\
\text { DIS- } \\
\text { SOLVED } \\
\text { (mg/L } \\
\text { AS K) }\end{array}$ & $\begin{array}{l}\text { CHLO- } \\
\text { RIDE, } \\
\text { DIS- } \\
\text { SOLVED } \\
(\mathrm{mg} / \mathrm{L} \\
\text { AS Cl) } \\
\end{array}$ & $\begin{array}{l}\text { SULFATE, } \\
\text { DIS- } \\
\text { SOLVED } \\
(\mathrm{mg} / \mathrm{L} \\
\left.\text { AS } \mathrm{SO}_{4}\right) \\
\end{array}$ & $\begin{array}{l}\text { IRON, } \\
\text { TOTAL } \\
\text { RECOV- } \\
\text { ERABLE } \\
(\mu \mathrm{g} / \mathrm{L} \\
\text { AS Fe) }\end{array}$ & $\begin{array}{l}\text { MANGA- } \\
\text { NESE, } \\
\text { TOTAL } \\
\text { RECOV- } \\
\text { ERABLE } \\
(\mu \mathrm{g} / \mathrm{L} \\
\text { AS Mn) }\end{array}$ & $\begin{array}{l}\text { SOLIDS, } \\
\text { SUM OF } \\
\text { CONSTI- } \\
\text { TUENTS, } \\
\text { DIS- } \\
\text { SOLVED } \\
(\mathrm{mg} / \mathrm{L})\end{array}$ \\
\hline \multirow[t]{17}{*}{ Mo3 } & $12-05-89$ & 0.030 & 0.003 & 390 & 110 & 27 & 130 & 3.0 & 240 & 80 & 150 & -- & 740 \\
\hline & $03-20-90$ & 0.005 & 0.004 & 380 & 110 & 28 & 130 & 2.4 & 240 & 79 & 130 & -- & 777 \\
\hline & $06-07-90$ & 0.015 & 0.003 & 390 & 110 & 28 & 130 & 2.5 & 240 & 75 & 120 & -- & 790 \\
\hline & $09-26-90$ & 0.030 & 0.003 & 390 & 110 & 26 & 120 & 2.5 & 240 & 38 & 360 & -- & 766 \\
\hline & $01-09-91$ & 0.005 & 0.004 & 380 & 110 & 27 & 120 & 3.0 & 230 & 68 & 110 & -- & 756 \\
\hline & $04-03-91$ & 0.010 & 0.005 & 380 & 110 & 26 & 130 & 3.0 & 230 & 85 & 70 & -- & 737 \\
\hline & $06-12-91$ & 0.010 & $<0.002$ & 390 & 110 & 26 & 120 & 2.8 & 230 & 68 & 100 & -- & 758 \\
\hline & $09-11-91$ & 0.010 & 0.004 & 380 & 110 & 28 & 130 & 2.6 & 230 & 15 & 130 & -- & 748 \\
\hline & $12-18-91$ & 0.005 & 0.005 & 380 & 110 & 26 & 130 & 3.2 & 230 & 86 & 70 & -- & 769 \\
\hline & $03-18-92$ & 0.010 & 0.005 & 380 & 100 & 27 & 130 & 3.8 & 230 & 77 & 180 & -- & 751 \\
\hline & $06-24-92$ & 0.010 & 0.003 & 380 & 100 & 28 & 130 & 2.8 & 240 & 80 & 340 & -- & 757 \\
\hline & $09-10-92$ & 0.015 & 0.005 & 380 & 100 & 26 & 130 & 3.0 & 250 & 91 & 290 & -- & 758 \\
\hline & $12-08-92$ & 0.010 & 0.004 & 370 & 110 & 27 & 130 & 2.5 & 240 & 100 & 360 & -- & 760 \\
\hline & $03-09-93$ & 0.010 & 0.004 & 370 & 100 & 26 & 120 & 2.3 & 230 & 87 & 180 & -- & -- \\
\hline & $06-22-93$ & 0.005 & 0.003 & 370 & 120 & 33 & 120 & 5.2 & 220 & 86 & 140 & -- & 753 \\
\hline & $09-16-93$ & 0.010 & 0.006 & 370 & 100 & 25 & 130 & 2.1 & 230 & 88 & 310 & -- & 760 \\
\hline & $04-06-94$ & 0.015 & 0.002 & 390 & 130 & 28 & 80 & 2.4 & 240 & 91 & 460 & 380 & 764 \\
\hline \multirow[t]{17}{*}{ Mo 2} & $12-05-89$ & 0.040 & 0.002 & 310 & 87 & 22 & 74 & 1.6 & 140 & 74 & 340 & -- & 516 \\
\hline & $03-20-90$ & 0.042 & 0.002 & 290 & 80 & 21 & 61 & 1.3 & 120 & 71 & 630 & -- & 488 \\
\hline & $06-07-90$ & 0.055 & 0.002 & 300 & 82 & 20 & 70 & 1.5 & 130 & 74 & 820 & + & 570 \\
\hline & $09-26-90$ & 0.028 & 0.003 & 290 & 74 & 20 & 80 & 1.3 & 140 & 38 & 470 & -- & 536 \\
\hline & $01-09-91$ & 0.020 & 0.002 & 290 & 76 & 20 & 62 & 1.6 & 110 & 68 & 340 & -- & 500 \\
\hline & $04-03-91$ & 0.013 & 0.004 & 290 & 80 & 20 & 58 & 1.5 & 110 & 77 & 330 & -- & 468 \\
\hline & $06-12-91$ & 0.025 & 0.002 & 290 & 82 & 20 & 78 & 1.6 & 150 & 68 & 400 & -- & 538 \\
\hline & $09-11-91$ & 0.018 & 0.002 & 280 & 78 & 15 & 72 & 1.5 & 130 & 74 & 320 & -- & 516 \\
\hline & $12-18-91$ & 0.018 & 0.004 & 290 & 81 & 20 & 77 & 1.7 & 140 & 80 & 290 & -- & 555 \\
\hline & $03-18-92$ & 0.025 & 0.003 & 300 & 82 & 22 & 66 & 2.1 & 130 & 75 & 200 & -- & 491 \\
\hline & $06-24-92$ & 0.030 & 0.002 & 310 & 88 & 22 & 75 & 1.6 & 140 & 72 & 460 & -- & 544 \\
\hline & $09-10-92$ & 0.045 & 0.006 & 300 & 84 & 21 & 70 & 1.6 & 140 & 84 & 1,600 & -- & 544 \\
\hline & $12-08-92$ & 0.015 & 0.003 & 300 & 85 & 22 & 61 & 1.4 & 130 & 85 & 400 & -- & 553 \\
\hline & $03-09-93$ & 0.025 & 0.002 & 310 & 84 & 22 & 61 & 1.3 & 140 & 81 & 810 & -- & -- \\
\hline & $06-22-93$ & 0.063 & 0.003 & 300 & 90 & 23 & 80 & 1.4 & 140 & 81 & 760 & -- & 580 \\
\hline & $09-16-93$ & 0.025 & 0.037 & 300 & 85 & 20 & 75 & 1.2 & 140 & -- & 480 & -- & 520 \\
\hline & $04-06-94$ & 0.010 & $<0.002$ & 320 & 79 & 23 & 66 & 1.4 & 140 & 88 & 240 & 400 & 513 \\
\hline \multirow[t]{12}{*}{ Mo6 63} & $04-03-91$ & 0.480 & 0.003 & 860 & 220 & 54 & 58 & 0.46 & 230 & $<10$ & 4,000 & -- & 933 \\
\hline & $06-12-91$ & 0.330 & $<0.002$ & 780 & 220 & 51 & 62 & 0.48 & 220 & $<10$ & 16,000 & -- & 964 \\
\hline & $09-11-91$ & 0.140 & 0.002 & 760 & 210 & 60 & 67 & 0.81 & 250 & $<10$ & 6,100 & - & 969 \\
\hline & $12-18-91$ & 0.170 & 0.002 & 760 & 220 & 52 & 73 & 1.0 & 240 & $<10$ & 12,000 & -- & 932 \\
\hline & $03-18-92$ & 0.210 & 0.003 & 780 & 220 & 56 & 53 & 1.2 & 210 & $<10$ & 13,000 & -- & 950 \\
\hline & $06-24-92$ & 0.300 & 0.002 & 770 & 210 & 58 & 63 & 0.80 & 220 & $<10$ & 19,000 & -- & 919 \\
\hline & $09-09-92$ & 0.220 & $<0.002$ & 760 & 210 & 55 & 65 & 0.78 & 210 & $<10$ & 9,600 & -- & 979 \\
\hline & $12-08-92$ & 0.240 & 0.002 & 800 & 220 & 55 & 68 & 0.60 & 240 & $<5.0$ & 13,000 & -- & 1,000 \\
\hline & $03-09-93$ & 0.270 & 0.002 & 800 & 210 & 54 & 54 & 0.32 & 210 & 6.0 & 16,000 & $\ldots$ & - \\
\hline & $06-22-93$ & 0.250 & 0.004 & 780 & 220 & 48 & 68 & $<0.50$ & 220 & $<5.0$ & 4,200 & -- & 1,010 \\
\hline & $09-16-93$ & 0.320 & 0.002 & 750 & 210 & 52 & 74 & $<0.50$ & 260 & 5.0 & 14,000 & -- & 1,000 \\
\hline & $04-06-94$ & 0.350 & $<0.002$ & 1,300 & 250 & 59 & 57 & $<0.25$ & 230 & 7.0 & 18,000 & 1,500 & 958 \\
\hline \multirow[t]{13}{*}{ Mo664 } & $01-09-91$ & 0.170 & 0.003 & 5,100 & 1,300 & 450 & 2,300 & 30 & 6,700 & 480 & 33,000 & -- & 11,100 \\
\hline & $04-03-91$ & 0.330 & 0.003 & 5,900 & 1,500 & 470 & 2,400 & 30 & 7,500 & 380 & 36,000 & -- & 12,600 \\
\hline & $06-12-91$ & 0.290 & $<0.002$ & 6,900 & 1,800 & 610 & 2,600 & 36 & 8,500 & 150 & 56,000 & -- & 14,400 \\
\hline & $09-11-91$ & 2.75 & 0.002 & 6,200 & -- & -- & 3,000 & 24 & 8,100 & 510 & 25,000 & -- & 13,800 \\
\hline & $12-18-91$ & 0.300 & 0.004 & 5,600 & 1,400 & 480 & 3,000 & 31 & 7,100 & 550 & 32,000 & -- & 12,800 \\
\hline & $03-18-92$ & 0.290 & 0.003 & 4,800 & 550 & 450 & 2,000 & 37 & 6,400 & 310 & 18,000 & -- & 11,000 \\
\hline & $06-24-92$ & 0.250 & 0.010 & 5,800 & 1,400 & 510 & 2,700 & 32 & 7,400 & 560 & 37,000 & -- & 14,000 \\
\hline & $09-09-92$ & -- & $<0.002$ & 6,000 & 1,400 & 520 & 2,700 & 34 & 7,800 & 590 & 30,000 & -- & 13,300 \\
\hline & $12-08-92$ & 0.260 & 0.003 & 5,900 & 1,400 & 520 & 2,500 & 26 & 7,700 & 660 & 29,000 & + & 13,900 \\
\hline & $03-09-93$ & 0.270 & 0.002 & 6,200 & 1,500 & 490 & 2,600 & 29 & 7,800 & 630 & 34,000 & -- & -- \\
\hline & $06-22-93$ & 0.300 & 0.036 & 6.100 & - - & -- & -- & -- & 8,100 & 660 & -- & -- & 14,900 \\
\hline & $09-16-93$ & 0.275 & 0.004 & 6,600 & 1,700 & 550 & 3,000 & 24 & 8,700 & -- & 40,000 & -- & 16,200 \\
\hline & $04-06-94$ & 0.300 & 0.026 & 5,900 & 1,300 & 420 & -- & 24 & 7,300 & 690 & 27,000 & 4,800 & 14,600 \\
\hline
\end{tabular}


Table A-2. Analyses of ground-water samples from observation wells in vicinity of the Ellison Park wetland, Monroe County, N.Y., December 1989 through April 1994--continued

[Well locations are shown in fig. 2. $\mu \mathrm{S} / \mathrm{cm}$, microsiemens per centimeter; $\mathrm{mg} / \mathrm{L}$, milligrams per liter; $\mu \mathrm{g} / \mathrm{L}$, micrograms per liter; <, less than;--, no data.]

\begin{tabular}{|c|c|c|c|c|c|c|c|c|c|c|}
\hline $\begin{array}{l}\text { STATION NUMBER } \\
\text { AND } \\
\text { LOCAL WELL } \\
\text { NUMBER }\end{array}$ & DATE & $\begin{array}{l}\text { TUR- } \\
\text { BID- } \\
\text { ITY } \\
\text { (UNITS) }\end{array}$ & $\begin{array}{l}\text { COLOR } \\
\text { (PLAT- } \\
\text { INUM- } \\
\text { COBALT } \\
\text { UNITS) }\end{array}$ & $\begin{array}{l}\text { SPE- } \\
\text { CIFIC } \\
\text { CON- } \\
\text { DUCT- } \\
\text { ANCE } \\
(\mu S / C m)\end{array}$ & $\begin{array}{l}\text { OXYGEN, } \\
\text { DIS- } \\
\text { SOLVED } \\
(\mathrm{mg} / \mathrm{L})\end{array}$ & $\begin{array}{c}\mathrm{pH} \\
\text { WATER } \\
\text { WHOLE } \\
\text { LAB } \\
\text { (STAND- } \\
\text { ARD } \\
\text { UNITS) }\end{array}$ & $\begin{array}{c}\text { ALKA- } \\
\text { LINITY, } \\
\text { CARBON- } \\
\text { ATE } \\
(\mathrm{mg} / \mathrm{L} \\
\left.\mathrm{CaCO}_{3}\right)\end{array}$ & $\begin{array}{c}\text { NITRO- } \\
\text { GEN, } \\
\text { AMMONIA } \\
\text { DIS- } \\
\text { SOLVED } \\
\text { (mg/L } \\
\text { AS N) }\end{array}$ & $\begin{array}{c}\text { NITRO- } \\
\text { GEN, AM- } \\
\text { MONIA + } \\
\text { ORGANIC } \\
\text { TOTAL } \\
\text { (mg/L } \\
\text { AS N) }\end{array}$ & $\begin{array}{c}\text { NITRO- } \\
\text { GEN, } \\
\text { NO2+NO3 } \\
\text { TOTAL } \\
(\mathrm{mg} / \mathrm{L} \\
\text { AS N) }\end{array}$ \\
\hline \multirow{13}{*}{$\begin{array}{c}430928077313802 \\
\text { Mo665 }\end{array}$} & $01-09-91$ & 100 & 42 & 1,900 & -- & 7.0 & 760 & 1.90 & 3.5 & 0.030 \\
\hline & $04-04-91$ & 70 & 45 & 1,940 & $<0.1$ & 7.1 & 760 & 1.80 & 1.7 & 0.00 \\
\hline & $06-13-91$ & 50 & 45 & 900 & $<0.1$ & 7.1 & 770 & 1.70 & 3.6 & 0.140 \\
\hline & $09-11-91$ & 80 & 50 & 1,970 & 0.1 & 7.3 & 780 & 2.00 & -- & $<0.050$ \\
\hline & $12-19-91$ & 75 & 47 & 1,970 & -- & 7.1 & $-\ldots$ & 1.90 & 3.4 & $<0.050$ \\
\hline & $03-18-92$ & 60 & 43 & 1,910 & -- & 7.1 & 790 & 1.90 & 3.4 & $<0.050$ \\
\hline & $05-24-92$ & 75 & 45 & 1,990 & $<0.1$ & 7.2 & 770 & 1.90 & 4.5 & $<0.050$ \\
\hline & $09-10-92$ & 75 & 42 & 1,980 & 0.1 & 7.2 & 790 & 2.00 & 3.1 & $<0.050$ \\
\hline & $12-09-92$ & 65 & 40 & 1,970 & 0.1 & 7.1 & 790 & 2.10 & 3.4 & $<0.050$ \\
\hline & $03-10-93$ & 75 & 40 & 1,970 & 0.4 & 7.1 & 770 & 2.00 & 4.2 & $<0.050$ \\
\hline & $07-07-93$ & 75 & 43 & 1,930 & $<0.1$ & 7.2 & 790 & 2.00 & 3.5 & $<0.050$ \\
\hline & $09-16-93$ & 55 & 49 & 1,970 & $<0.1$ & 7.1 & 790 & 1.90 & 3.9 & $<0.050$ \\
\hline & $04-06-94$ & 60 & 45 & 1,960 & $<0.1$ & 7.1 & 790 & 1.80 & 5.3 & $<0.050$ \\
\hline \multirow{15}{*}{$\begin{array}{c}430928077313803 \\
\text { Mo666 } \\
430928077314001 \\
\text { Mo667 }\end{array}$} & $09-16-93$ & 95 & 25 & 1,830 & $<0.1$ & 7.1 & 850 & 7.50 & 8.3 & $<0.050$ \\
\hline & $04-06-94$ & 130 & 20 & 1,900 & $<0.1$ & 7.2 & 850 & 8.40 & 11 & $<0.050$ \\
\hline & $01-09-91$ & 160 & 27 & 2,080 & -- & 7.1 & 870 & 12.0 & 13 & 0.030 \\
\hline & $04-04-91$ & 220 & 28 & 1,720 & -- & 7.3 & 820 & 9.80 & 12 & 0.00 \\
\hline & $06-13-91$ & 100 & 30 & 1,370 & -- & 7.3 & 980 & 14.5 & 13 & 0.100 \\
\hline & $09-11-91$ & 170 & 30 & 2,480 & -- & 7.3 & 1,050 & 22.0 & -- & 0.060 \\
\hline & $12-18-91$ & -- & 30 & 2,530 & -- & 7.1 & 830 & 16.0 & 16 & $<0.050$ \\
\hline & $03-18-92$ & 220 & 30 & 1,880 & 0.7 & 7.4 & 830 & 12.0 & 12 & $<0.050$ \\
\hline & $06-24-92$ & 100 & 30 & 2,440 & 1.4 & 7.3 & 1,060 & 12.0 & 16 & $<0.050$ \\
\hline & $09-10-92$ & 220 & 28 & 2,370 & -- & 7.8 & 1,050 & 14.0 & 14 & $<0.050$ \\
\hline & $12-09-92$ & 270 & 40 & 2,330 & 0.2 & 7.0 & 1,020 & 14.0 & 14 & $<0.050$ \\
\hline & $03-10-93$ & 300 & 30 & 2,160 & $<0.1$ & 7.1 & 930 & 12.0 & 12 & $<0.050$ \\
\hline & $07-07-93$ & 250 & 23 & 2,850 & $<0.1$ & 7.1 & 850 & 15.0 & 17 & $<0.050$ \\
\hline & $09-16-93$ & 510 & 30 & 2,970 & $<0.1$ & 7.2 & 820 & 18.0 & 18 & $<0.050$ \\
\hline & $04-06-94$ & 270 & 35 & 1,880 & 1.3 & 7.2 & 800 & 10.0 & 11 & $<0.050$ \\
\hline \multirow{13}{*}{$\begin{array}{c}430928077314002 \\
\text { Mo668 }\end{array}$} & $01-09-91$ & 160 & 18 & 2,880 & -- & 6.8 & 640 & 5.90 & 7.0 & 0.020 \\
\hline & $04-04-91$ & 200 & 24 & 2,860 & $<0.1$ & 6.9 & 650 & 5.90 & 6.8 & 0.140 \\
\hline & $06-13-91$ & 190 & 23 & 2,650 & $<0.2$ & 6.9 & 640 & 4.90 & 7.3 & 1.20 \\
\hline & $09-11-91$ & 240 & 25 & 2,780 & 8.5 & 7.0 & 620 & 8.40 & - & $<0.050$ \\
\hline & $12-18-91$ & 280 & 20 & 2,800 & 9.3 & 7.0 & 650 & 7.10 & 7.4 & $<0.050$ \\
\hline & $03-18-92$ & 220 & 45 & 2,860 & $<0.1$ & 6.9 & 640 & 6.00 & 6.8 & $<0.050$ \\
\hline & $06-24-92$ & 150 & 35 & 2,800 & $<0.1$ & 7.0 & 640 & 6.40 & 9.4 & $<0.050$ \\
\hline & $09-10-92$ & 160 & 23 & 2,830 & $<0.1$ & 6.9 & 640 & 6.00 & 7.8 & $<0.050$ \\
\hline & $12-09-92$ & 75 & 40 & 2,800 & $<0.1$ & 6.9 & 630 & 5.00 & 7.1 & $<0.050$ \\
\hline & $03-09-93$ & 230 & 20 & 2,820 & 0.3 & 7.0 & 640 & 5.40 & 6.4 & $<0.050$ \\
\hline & $07-07-93$ & 230 & 14 & 2,600 & $<0.1$ & 7.0 & 650 & 5.30 & 7.0 & $<0.050$ \\
\hline & $09-16-93$ & 170 & 20 & 2,580 & $<0.1$ & 6.9 & 580 & 6.70 & 7.6 & $<0.050$ \\
\hline & $04-06-94$ & 50 & 20 & 2,710 & $<0.1$ & 6.8 & 660 & 5.00 & -- & $<0.050$ \\
\hline \multirow{13}{*}{$\begin{array}{c}430932077311501 \\
\text { Mo659 }\end{array}$} & $01-09-91$ & 9.0 & 6 & 510 & 0.4 & 9.4 & 35 & $<0.010$ & 0.24 & $<0.010$ \\
\hline & $04-04-91$ & 9.1 & 1.2 & 522 & 0.3 & 9.5 & 30 & $<0.010$ & $<0.10$ & 0.00 \\
\hline & $06-12-91$ & 13 & 10 & 523 & $<0.1$ & 9.5 & 32 & $<0.010$ & 0.86 & 0.110 \\
\hline & $09-11-91$ & 9.0 & 5 & 538 & 12.6 & 9.2 & 29 & $<0.010$ & 0.35 & $<0.050$ \\
\hline & $12-18-91$ & 9.2 & 8 & 551 & 11.5 & 8.4 & 30 & 0.020 & 0.22 & $<0.050$ \\
\hline & $03-18-92$ & 15 & 14 & 510 & 0.4 & 9.3 & 30 & 0.010 & 0.21. & $<0.050$ \\
\hline & $06-24-92$ & 12 & 5 & 564 & 0.9 & 9.0 & 33 & $<0.010$ & 0.53 & $<0.050$ \\
\hline & $09-09-92$ & 6.6 & 5 & 579 & 0.4 & 9.0 & 32 & 0.010 & 0.40 & $<0.050$ \\
\hline & $12-08-92$ & 12 & 5 & 576 & 1.0 & 8.3 & 32 & 0.010 & 0.12 & $<0.050$ \\
\hline & $03-09-93$ & 6.8 & 5 & 1,590 & 2.4 & 9.3 & 51 & $<0.010$ & 0.15 & $<0.050$ \\
\hline & $07-07-93$ & 11 & 6 & 866 & 6.2 & 8.0 & 86 & $<0.010$ & 0.23 & $<0.050$ \\
\hline & $04-29-94$ & 7.8 & 6 & 863 & -- & 8.2 & 76 & 0.020 & 0.57 & $<0.050$ \\
\hline & $04-29-94$ & 80 & 40 & 1,230 & -- & 7.5 & 210 & 0.080 & 0.63 & $<0.050$ \\
\hline
\end{tabular}


Table A-2. Analyses of ground-water samples from observation wells in vicinity of the Ellison Park wetland, Monroe County, N.Y., December 1989 through April 1994--continued

[Well locations are shown in fig. $2 . \mu \mathrm{S} / \mathrm{cm}$, microsiemens per centimeter; mg/L, milligrams per liter; $\mu \mathrm{g} / \mathrm{L}$, micrograms per liter; $<$, less than;--, no data.]

\begin{tabular}{|c|c|c|c|c|c|c|c|c|c|c|c|c|c|}
\hline $\begin{array}{l}\text { LOCAL } \\
\text { WELL } \\
\text { NUM- } \\
\text { BER }\end{array}$ & DATE & $\begin{array}{c}\text { PHOS- } \\
\text { PHORUS } \\
\text { TOTAL } \\
(\mathrm{mg} / \mathrm{L} \\
\text { AS P) }\end{array}$ & $\begin{array}{c}\text { PHOS- } \\
\text { PHORUS } \\
\text { ORTHO, } \\
\text { DIS- } \\
\text { SOLVED } \\
(\mathrm{mg} / \mathrm{L} \\
\text { AS P) }\end{array}$ & $\begin{array}{l}\text { HARD- } \\
\text { NESS, } \\
\text { TOTAL } \\
\text { (mg/L } \\
\mathrm{AS} \\
\mathrm{CaCO}_{3} \text { ) }\end{array}$ & $\begin{array}{l}\text { CALCIUM, } \\
\text { TOTAL } \\
\text { RECOV- } \\
\text { ERABLE } \\
(\mathrm{mg} / \mathrm{L} \\
\text { AS Ca) } \\
\end{array}$ & $\begin{array}{c}\text { MAGNE- } \\
\text { SIUM, } \\
\text { DIS- } \\
\text { SOLVED } \\
\text { (mg/L } \\
\text { AS Mg) }\end{array}$ & $\begin{array}{l}\text { SODIUM, } \\
\text { DIS- } \\
\text { SOLVED } \\
(\mathrm{mg} / \mathrm{L} \\
\text { AS Na) }\end{array}$ & $\begin{array}{l}\text { POTAS- } \\
\text { SIUM, } \\
\text { DIS- } \\
\text { SOLVED } \\
(\mathrm{mg} / \mathrm{L} \\
\text { AS K) }\end{array}$ & $\begin{array}{l}\text { CHLO- } \\
\text { RIDE, } \\
\text { DIS- } \\
\text { SOLVED } \\
\text { (mg/L } \\
\text { AS Cl) }\end{array}$ & $\begin{array}{l}\text { SULFATE, } \\
\text { DIS- } \\
\text { SOLVED } \\
(\mathrm{mg} / \mathrm{L} \\
\left.\mathrm{AS} \mathrm{SO}_{4}\right)\end{array}$ & $\begin{array}{l}\text { IRON, } \\
\text { TOTAL } \\
\text { RECOV- } \\
\text { ERABLE } \\
(\mu g / L \\
\text { AS Fe) }\end{array}$ & $\begin{array}{l}\text { MANGA- } \\
\text { NESE, } \\
\text { TOTAL } \\
\text { RECOV- } \\
\text { ERABLE } \\
(\mu \mathrm{g} / \mathrm{L} \\
\text { AS Mn) }\end{array}$ & $\begin{array}{c}\text { SOLIDS, } \\
\text { SUM OF } \\
\text { CONSTI- } \\
\text { TUENTS, } \\
\text { DIS- } \\
\text { SOLVED } \\
(\mathrm{mg} / \mathrm{L})\end{array}$ \\
\hline \multirow[t]{13}{*}{ Mo665 } & $01-09-91$ & 0.300 & 0.004 & 580 & 180 & 35 & 230 & 0.80 & 240 & $<10$ & 12,000 & -- & 1,210 \\
\hline & $04-04-91$ & 0.240 & 0.003 & 580 & 170 & 34 & 240 & 0.76 & 230 & $<10$ & 27,000 & -- & 1,220 \\
\hline & $06-13-91$ & 0.160 & 0.004 & 590 & 170 & 33 & 260 & 0.70 & 240 & $<10$ & 6,900 & -- & 1,240 \\
\hline & $09-11-91$ & 0.260 & 0.004 & 570 & 160 & 7.0 & 260 & 0.88 & 240 & $<10$ & 13,000 & -- & 1,240 \\
\hline & $12-19-91$ & 0.300 & 0.004 & 580 & 170 & 34 & 270 & 1.0 & 240 & $<10$ & 9,700 & -- & 1,220 \\
\hline & $03-18-92$ & 0.250 & 0.004 & 590 & 180 & 37 & 230 & 1.2 & 240 & $<10$ & 9,900 & -- & 1,240 \\
\hline & $06-24-92$ & 0.280 & 0.002 & 560 & 170 & 39 & 250 & 0.70 & 240 & $<10$ & 7,600 & -- & 1,230 \\
\hline & $09-10-92$ & 0.280 & 0.003 & 590 & 180 & 38 & 250 & 0.99 & 240 & $<10$ & 7,300 & -- & 1.260 \\
\hline & $12-09-92$ & 0.370 & 0.006 & 600 & 170 & 34 & 240 & 0.60 & 240 & 6.0 & 12,000 & -- & 1,240 \\
\hline & $03-10-93$ & 0.290 & 0.003 & 610 & 170 & 35 & 220 & 0.48 & 240 & 7.0 & 12,000 & -- & -- \\
\hline & $07-07-93$ & 0.275 & 0.004 & 650 & 180 & 36 & 270 & $<0.50$ & 230 & 5.0 & 8,400 & -- & 1,260 \\
\hline & $09-16-93$ & 0.320 & 0.006 & 600 & 270 & 33 & 250 & $<0.50$ & 240 & 8.0 & 11,000 & -- & 1.230 \\
\hline & $04-06-94$ & 0.430 & $<0.002$ & 690 & 180 & 38 & 100 & 0.42 & 240 & $<1.0$ & 13,000 & 1,900 & 1,230 \\
\hline \multirow[t]{2}{*}{ Mo666 } & $09-16-93$ & 0.290 & 0.003 & 730 & 220 & 52 & 160 & 4.8 & 160 & -- & 19,000 & -- & 1,070 \\
\hline & $04-06-94$ & 0.420 & $<0.002$ & 1.600 & 180 & 55 & 130 & 9.3 & 150 & 12 & 24,000 & 1,000 & 1,030 \\
\hline \multirow[t]{13}{*}{ Mo 667} & $01-09-91$ & 0.710 & 0.003 & 750 & 200 & 53 & 170 & 23 & 220 & 10 & 18,000 & -- & 1,250 \\
\hline & $04-04-91$ & 1.65 & 0.004 & 690 & 200 & 52 & 100 & 21 & 130 & $<10$ & 25,000 & -- & 1,000 \\
\hline & $06-13-91$ & 3.90 & 0.003 & 880 & 250 & 62 & 170 & 25 & 250 & $<10$ & 13,000 & -- & 1,390 \\
\hline & $09-11-91$ & 0.990 & 0.004 & 910 & 240 & 71 & 230 & 22 & 280 & $<10$ & 18,000 & -- & 1,170 \\
\hline & $12-18-91$ & 1.60 & 0.004 & 990 & 290 & 73 & 210 & 31 & 310 & 10 & 53,000 & -- & 1,500 \\
\hline & $03-18-92$ & 1.60 & 0.003 & 820 & 220 & 60 & 100 & 23 & 120 & 84 & 19,000 & -- & 1,160 \\
\hline & $06-24-92$ & 1.50 & 0.009 & 990 & 270 & 74 & 190 & 26 & 270 & $<10$ & 14,000 & -- & 1,490 \\
\hline & $09-10-92$ & 1.85 & 0.004 & 930 & 280 & 37 & 180 & 29 & 240 & $<10$ & 20,000 & -- & 1,460 \\
\hline & $12-09-92$ & 2.80 & 0.004 & 910 & 250 & 65 & 170 & 23 & 250 & $<5.0$ & 39,000 & -- & 1,400 \\
\hline & $03-10-93$ & 3.60 & 0.004 & 910 & 240 & 61 & 130 & 22 & 230 & 7.0 & 44,000 & -- & -- \\
\hline & $07-07-93$ & 1.75 & 0.006 & 1,100 & 290 & 71 & 230 & 28 & 530 & $<5.0$ & 28,000 & -- & 1,730 \\
\hline & $09-16-93$ & 11.0 & 0.007 & 950 & 260 & 62 & 280 & 25 & 550 & 7.0 & 55,000 & -- & 1,710 \\
\hline & $04-06-94$ & 3.65 & $<0.002$ & 1,000 & 210 & 51 & 180 & 13 & 190 & 24 & 33,000 & 2,000 & 1,120 \\
\hline \multirow[t]{13}{*}{ Mo668 } & $01-09-91$ & 0.160 & 0.003 & 860 & 220 & 72 & 280 & 6.7 & 620 & $<10$ & 27,000 & -- & 1,610 \\
\hline & $04-04-91$ & 0.460 & 0.003 & 920 & 210 & 73 & 280 & 6.0 & 700 & $<10$ & 31,000 & -- & 1,560 \\
\hline & $06-13-91$ & 0.250 & 0.002 & 840 & 220 & 70 & 310 & 6.2 & 670 & $<10$ & 23,000 & -- & 1,610 \\
\hline & $09-11-91$ & 0.320 & 0.002 & 860 & 220 & 27 & 290 & 5.0 & 690 & $<10$ & 24,000 & -- & 1,540 \\
\hline & $12-18-91$ & 0.260 & 0.003 & 860 & 220 & 69 & 390 & 6.1 & 580 & $<10$ & 33,000 & -- & 1,560 \\
\hline & $03-18-92$ & 0.480 & 0.003 & 820 & 220 & 74 & 290 & 7.8 & 620 & $<10$ & 18,000 & -- & 1,560 \\
\hline & $06-24-92$ & 0.660 & 0.003 & 840 & 220 & 74 & 310 & 5.7 & 590 & $<10$ & 40,000 & -- & 1,550 \\
\hline & $09-10-92$ & 0.580 & 0.002 & 830 & 230 & 70 & 270 & 8.1 & 600 & $<10$ & 23,000 & -- & 1,570 \\
\hline & $12-09-92$ & 0.640 & 0.003 & 860 & 220 & 73 & 270 & 5.0 & 610 & $<5.0$ & 31,000 & -- & 1,560 \\
\hline & $03-09-93$ & 0.620 & 0.003 & 860 & 210 & 72 & 260 & 4.9 & 600 & 6.0 & 34,000 & -- & - \\
\hline & $07-07-93$ & 0.630 & 0.004 & 830 & 210 & 69 & 280 & 4.9 & 570 & $<5.0$ & 26,000 & -- & 1,530 \\
\hline & $09-16-93$ & 0.190 & 0.004 & 770 & 210 & 64 & 250 & 4.5 & 540 & 6.0 & 30,000 & -- & 1,420 \\
\hline & $04-06-94$ & 0.690 & $<0.002$ & 1,900 & 230 & 76 & 240 & 4.8 & 580 & 4.0 & 30,000 & 1,200 & 1,540 \\
\hline \multirow[t]{13}{*}{ Mo659 } & $01-09-91$ & $<0.005$ & 0.003 & 90 & 11 & 16 & 57 & 8.0 & 140 & $<10$ & 3,400 & -- & 248 \\
\hline & $04-04-91$ & 0.005 & 0.003 & 92 & 11 & 17 & 57 & 7.9 & 140 & $<10$ & 2,200 & -- & 235 \\
\hline & $06-12-91$ & $<0.005$ & $<0.002$ & 95 & 4.0 & 9.0 & 60 & 8.0 & 140 & $<10$ & 7,800 & -- & 268 \\
\hline & $09-11-91$ & $<0.005$ & 0.002 & 97 & 12 & 18 & 58 & 6.4 & 150 & 40 & 2,000 & -- & 252 \\
\hline & $12-18-91$ & $<0.005$ & 0.002 & 100 & 10 & 18 & 66 & 18 & 220 & $<10$ & 3,100 & -- & 262 \\
\hline & $03-18-92$ & 0.005 & $<0.002$ & 110 & 10 & 20 & 57 & 8.7 & 210 & $<10$ & 4,200 & -- & 264 \\
\hline & $06-24-92$ & $<0.005$ & $<0.002$ & 100 & 9.0 & 20 & 61 & 7.3 & 150 & $<10$ & 5,000 & -- & 277 \\
\hline & $09-09-92$ & $<0.005$ & $<0.002$ & 100 & 32 & 28 & 66 & 7.3 & 150 & $<10$ & 1,400 & -- & 283 \\
\hline & $12-08-92$ & 0.005 & 0.002 & 120 & 10 & 22 & 58 & 7.1 & 160 & $<5.0$ & 3,100 & -- & 288 \\
\hline & $03-09-93$ & 0.005 & 0.002 & 210 & 210 & 54 & 62 & 3.3 & 220 & 6.0 & 16,000 & -- & -- \\
\hline & $07-07-93$ & 0.005 & $<0.002$ & 280 & 23 & 46 & 72 & 3.2 & 230 & $<5.0$ & 3,200 & -- & 432 \\
\hline & $04-29-94$ & $<0.005$ & $<0.002$ & -- & 22 & 51 & 62 & 3.0 & 230 & $<1.0$ & 2,900 & 300 & 378 \\
\hline & $04-29-94$ & $<0.005$ & $<0.002$ & -- & 88 & 52 & 71 & 3.5 & 270 & 20 & 9,800 & 200 & 622 \\
\hline
\end{tabular}


Table A-3. Analyses of atmospheric deposition in northern part of Ellison Park wetland, Monroe County, N.Y., April 1992 through September 1994 (station 431021077315902)

[Sampling location is shown in fig.2. $\mu \mathrm{S} / \mathrm{cm}$, microsiemens per centimeter; $\mathrm{mg} / \mathrm{L}$, milligrams per liter; $\mu \mathrm{g} / \mathrm{L}$, micrograms per liter; <, less than; --, no data.]

Part A. Wetfall analyses

\begin{tabular}{|c|c|c|c|c|c|c|c|c|c|}
\hline DATE & $\begin{array}{l}\text { SPE- } \\
\text { CIFIC } \\
\text { CON- } \\
\text { DUCT- } \\
\text { ANCE } \\
(\mu S / \mathrm{Cm})\end{array}$ & $\begin{array}{c}\mathrm{pH} \\
\text { WATER } \\
\text { WHOLE } \\
\text { LAB } \\
\text { (STAND- } \\
\text { ARD } \\
\text { UNITS) }\end{array}$ & $\begin{array}{c}\text { ACIDITY } \\
(\mathrm{mg} / \mathrm{L} \\
\mathrm{AS} \\
\left.\mathrm{CACO}_{3}\right)\end{array}$ & $\begin{array}{c}\text { NITRO- } \\
\text { GEN, } \\
\text { AMMONIA } \\
\text { DIS- } \\
\text { SOLVED } \\
\text { (mg/L } \\
\text { AS N) }\end{array}$ & $\begin{array}{c}\text { NITRO- } \\
\text { GEN, AM- } \\
\text { MONIA + } \\
\text { ORGANIC } \\
\text { TOTAL } \\
(\mathrm{mg} / \mathrm{L} \\
\text { AS N) }\end{array}$ & $\begin{array}{l}\text { NITRO- } \\
\text { GEN, } \\
\text { NO2 +NO3 } \\
\text { TOTAL } \\
\text { (mg/L } \\
\text { AS N) }\end{array}$ & $\begin{array}{l}\text { PHOS- } \\
\text { PHORUS } \\
\text { TOTAL } \\
(\mathrm{mg} / \mathrm{L} \\
\text { AS P) }\end{array}$ & $\begin{array}{c}\text { PHOS- } \\
\text { PHORUS } \\
\text { ORTHO, } \\
\text { DIS- } \\
\text { SOLVED } \\
\text { (mg/L } \\
\text { AS P) }\end{array}$ & $\begin{array}{c}\text { CALCIUM, } \\
\text { DIS- } \\
\text { SOLVED } \\
\text { (mg/L } \\
\text { AS Ca) }\end{array}$ \\
\hline \multicolumn{10}{|l|}{ OCT $01-$} \\
\hline NOV 051992 & 730 & 4.7 & 3.3 & 0.550 & 0.64 & 0.600 & 0.075 & 0.047 & -- \\
\hline $\begin{array}{lll}\text { NOV } & 05-D E C & 02 \\
\text { DEC } & 02 & 1992-\end{array}$ & 53 & 4.2 & 8.1 & 0.600 & 0.64 & 0.970 & 0.020 & 0.011 & -- \\
\hline JAN 051993 & 17 & 6.1 & 0.9 & 0.280 & 0.34 & 0.340 & 0.025 & 0.006 & - - \\
\hline APR 14-MAY 07 & 78 & 3.9 & 11 & 0.790 & 1.2 & 1.70 & 0.050 & 0.015 & -- \\
\hline MAY 07 -JUN 02 & 36 & 4.0 & 5.8 & -- & 0.93 & 0.680 & 0.030 & 0.003 & -- \\
\hline JUN $\quad 02$-JUL 01 & 78 & 3.8 & 11 & 0.780 & 0.96 & 0.940 & 0.025 & $<0.002$ & -- \\
\hline JUL 01 -AUG 05 & 104 & 3.8 & 14 & 0.670 & 0.92 & 0.910 & 0.015 & $<0.002$ & -- \\
\hline AUG 05-SEP 02 & 113 & 3.7 & 15 & 1.10 & 1.2 & 1.40 & 0.020 & 0.006 & -- \\
\hline SEP 01-OCT 01 & 38 & 4.2 & 5.9 & 0.390 & 0.49 & 0.480 & 0.010 & 0.003 & 0.30 \\
\hline OCT 01-NOV 03 & 32 & 4.4 & 5.1 & 0.450 & 0.61 & 0.550 & 0.025 & 0.011 & 0.73 \\
\hline NOV $03-D E C \quad 02$ & 41 & 4.4 & 6.0 & 0.900 & 1.0 & 1.30 & 0.020 & 0.006 & 0.75 \\
\hline \multicolumn{10}{|l|}{ DEC 02 1993- } \\
\hline JAN $12 \quad 1994$ & 42 & 4.9 & 5.7 & 0.310 & 0.36 & 0.720 & 0.010 & 0.009 & 0.48 \\
\hline JAN $12-31$ & 8 & 4.9 & 1.9 & 0.110 & 0.14 & 0.220 & 0.005 & 0.004 & 0.08 \\
\hline JAN 31-MAR 01 & 13 & 6.0 & 1.2 & 0.050 & 0.19 & 0.310 & 0.005 & 0.004 & 0.40 \\
\hline MAR 01 -APR 01 & 11 & 6.3 & 1.5 & 0.070 & 0.23 & 0.290 & 0.010 & 0.003 & 0.56 \\
\hline APR 01-MAY 02 & 89 & 3.9 & 10 & 2.10 & 3.3 & 2.30 & 0.140 & 0.038 & 3.3 \\
\hline MAY 02-JUN 01 & 37 & 4.2 & 5.0 & 0.880 & 1.3 & 0.680 & 0.095 & 0.013 & 1.2 \\
\hline JUN $01-30$ & 44 & 3.6 & 9.4 & 0.440 & 0.50 & 0.580 & 0.025 & 0.002 & 0.30 \\
\hline JUN 30-JUL 29 & 97 & 3.3 & 16 & 1.40 & 1.6 & 1.40 & 0.050 & 0.011 & 1.3 \\
\hline JUL 29-AUG 31 & 81 & 3.5 & 12 & 0.710 & 0.87 & 0.980 & 0.040 & 0.003 & 0.58 \\
\hline AUG 31-OCT 03 & 79 & 3.9 & 10 & 1.00 & 1.1 & 1.30 & 0.045 & 0.002 & 1.2 \\
\hline DATE & $\begin{array}{l}\text { CALCIUM, } \\
\text { TOTAL } \\
\text { RECOV- } \\
\text { ERABLE } \\
\text { (mg/L } \\
\text { AS Ca) }\end{array}$ & $\begin{array}{l}\text { MAGNE- } \\
\text { SIUM, } \\
\text { DIS- } \\
\text { SOLVED } \\
\text { (mg/I } \\
\text { AS Mg) }\end{array}$ & $\begin{array}{l}\text { SODIUM, } \\
\text { DIS- } \\
\text { SOLVED } \\
\text { (mg/L } \\
\text { AS Na) }\end{array}$ & $\begin{array}{l}\text { POTAS- } \\
\text { SIUM, } \\
\text { DIS- } \\
\text { SOLVED } \\
\text { (mg/L } \\
\text { AS K) }\end{array}$ & $\begin{array}{l}\text { CHLO- } \\
\text { RIDE, } \\
\text { DIS- } \\
\text { SOLVED } \\
\text { (mg/L } \\
\text { AS Cl) }\end{array}$ & $\begin{array}{l}\text { SULFATE, } \\
\text { DIS- } \\
\text { SOLVED } \\
(\mathrm{mg} / \mathrm{L} \\
\left.\text { AS } \mathrm{SO}_{4}\right)\end{array}$ & $\begin{array}{l}\text { LEAD, } \\
\text { TOTAL } \\
\text { RECOV- } \\
\text { ERABLE } \\
(\mu \mathrm{g} / \mathrm{L} \\
\text { AS Pb) }\end{array}$ & $\begin{array}{l}\text { ZINC, } \\
\text { TOTAL } \\
\text { RECOV- } \\
\text { ERABLE } \\
(\mu g / L \\
\text { AS Zn) }\end{array}$ & \\
\hline \multicolumn{10}{|l|}{ OCT $01-$} \\
\hline NOV 051992 & 0.74 & 0.09 & 0.07 & 0.32 & 0.80 & 4.0 & $<5$ & $<40$ & \\
\hline NOV $05-D E C \quad 02$ & 0.60 & 0.15 & 0.20 & $<0.10$ & 0.30 & 5.0 & $<5$ & 30 & \\
\hline \multicolumn{10}{|l|}{ DEC $021992-$} \\
\hline JAN 051993 & 0.63 & 0.17 & 1.0 & 0.09 & 1.4 & 2.0 & 8 & $<40$ & \\
\hline APR 14-MAY 07 & 1.8 & 0.47 & 0.38 & 0.16 & 0.93 & 9.0 & 7 & 60 & \\
\hline MAY 07 -JUN 02 & 0.62 & 0.13 & 0.13 & 0.04 & 0.40 & -- & 25 & $<40$ & \\
\hline JUN 02-JUL 01 & 0.61 & 0.15 & 0.10 & 0.08 & 0.40 & - & 5 & 90 & \\
\hline JUL 01 -AUG 05 & 0.88 & 0.34 & 0.22 & 0.22 & 0.40 & 12 & $<5$ & $<40$ & \\
\hline AUG 05-SEP 02 & 0.75 & 0.18 & 0.12 & 0.13 & 0.51 & 12 & $<5$ & 50 & \\
\hline SEP 01 -OCT 01 & -- & 0.07 & 0.19 & -- & 0.32 & 4.3 & 6 & 40 & \\
\hline OCT 01-NOV 03 & -- & 0.21 & $<0.02$ & 0.05 & 0.41 & 4.0 & 6 & $<40$ & \\
\hline NOV $03-\mathrm{DEC} \quad 02$ & -- & 0.20 & 0.31 & 0.06 & 0.97 & 5.0 & $<5$ & $<40$ & \\
\hline \multicolumn{10}{|l|}{ DEC $021993-$} \\
\hline JAN $12 \quad 1994$ & -- & 0.12 & 1.5 & 0.01 & 2.2 & 2.0 & 8 & $<40$ & \\
\hline JAN $12-31$ & - & 0.03 & 0.11 & $<0.01$ & 0.20 & $<2.0$ & $<5$ & -- & \\
\hline JAN 31-MAR 01 & -- & 0.05 & 1.8 & 0.01 & 2.6 & $<2.0$ & 6 & 40 & \\
\hline MAR $01-A P R \quad 01$ & -- & 0.09 & -- & $<0.01$ & 0.58 & $<2.0$ & 4 & 40 & \\
\hline APR $01-M A Y ~ 02$ & -- & 0.80 & 0.38 & 0.20 & 0.99 & 15 & 9 & 40 & \\
\hline MAY 02 -JUN 01 & -- & 0.33 & $<0.20$ & -- & 0.80 & 6.5 & 5 & 40 & \\
\hline JUN $01-30$ & -- & $<0.10$ & 0.02 & 0.06 & 0.80 & 5.2 & 6 & $<40$ & \\
\hline JUN 30 -JUL 29 & - & 0.29 & 0.06 & 0.18 & 0.80 & 13 & 6 & 40 & \\
\hline JUL 29-AUG 31 & -- & 0.12 & 0.05 & 0.08 & 0.40 & 9.3 & $<5$ & $<40$ & \\
\hline AUG 31-OCT 03 & -- & 0.28 & 0.08 & 0.16 & 0.60 & 9.7 & 9 & $<40$ & \\
\hline
\end{tabular}


Table A-3. Analyses of atmospheric deposition in northern part of Ellison Park wetland, Monroe County, N.Y., April 1992 through September 1994 (station 431021077315902)--continued

[Sampling location is shown in fig. $2 . \mu \mathrm{S} / \mathrm{cm}$, microsiemens per centimeter; $\mathrm{mg} / \mathrm{L}$, milligrams per liter; $\mu \mathrm{g} / \mathrm{L}$, micrograms per liter; <, less than; --, no data.]

Part B. Dryfall analyses

\begin{tabular}{|c|c|c|c|c|c|c|c|c|c|}
\hline DATE & $\begin{array}{l}\text { SPE- } \\
\text { CIFIC } \\
\text { CON- } \\
\text { DUCT- } \\
\text { ANCE } \\
(\mu \mathrm{S} / \mathrm{Cm})\end{array}$ & $\begin{array}{c}\mathrm{pH} \\
\text { WATER } \\
\text { WHOLE } \\
\text { LAB } \\
\text { (STAND- } \\
\text { ARD } \\
\text { UNITS) }\end{array}$ & $\begin{array}{c}\text { ACIDITY } \\
(\mathrm{mg} / \mathrm{L} \\
\mathrm{AS} \\
\left.\mathrm{CACO}_{3}\right) \\
\end{array}$ & $\begin{array}{l}\text { NITRO- } \\
\text { GEN, } \\
\text { AMMONIA } \\
\text { DIS- } \\
\text { SOLVED } \\
\text { (mg/L } \\
\text { AS N) } \\
\end{array}$ & $\begin{array}{l}\text { NITRO- } \\
\text { GEN, AM- } \\
\text { MONIA + } \\
\text { ORGANIC } \\
\text { TOTAL } \\
\text { (mg/L } \\
\text { AS N) }\end{array}$ & $\begin{array}{c}\text { NITRO- } \\
\text { GEN, } \\
\text { NO2+NO3 } \\
\text { TOTAL } \\
(\mathrm{mg} / \mathrm{L} \\
\text { AS N) }\end{array}$ & $\begin{array}{c}\text { PHOS- } \\
\text { PHORUS } \\
\text { TOTAL } \\
(\mathrm{mg} / \mathrm{L} \\
\text { AS P) }\end{array}$ & $\begin{array}{c}\text { PHOS- } \\
\text { PHORUS } \\
\text { ORTHO, } \\
\text { DIS- } \\
\text { SOLVED } \\
\text { (mg/L } \\
\text { AS P) }\end{array}$ & $\begin{array}{l}\text { CALCIUM } \\
\text { DIS- } \\
\text { SOLVED } \\
(\mathrm{mg} / \mathrm{L} \\
\text { AS Ca) }\end{array}$ \\
\hline $\begin{array}{l}\text { NOV } 05- \\
\quad \text { DEC } 02 \quad 1992\end{array}$ & 4 & 6.5 & 0.9 & 0.070 & 0.10 & 0.160 & 0.015 & 0.005 & -- \\
\hline $\begin{array}{llll}\text { DEC } & 02 & 1992- \\
\text { JAN } & 05 & \mathbf{1 9 9 3} \\
\text { APR } & 14-\text { MAY } & 07\end{array}$ & $\begin{array}{l}38 \\
42\end{array}$ & $\begin{array}{l}4.3 \\
4.6\end{array}$ & $\begin{array}{l}4.6 \\
5.6\end{array}$ & $\begin{array}{l}0.300 \\
0.700\end{array}$ & $\begin{array}{l}0.28 \\
1.6\end{array}$ & $\begin{array}{l}0.460 \\
1.00\end{array}$ & $\begin{array}{l}0.015 \\
0.300\end{array}$ & $\begin{array}{l}0.008 \\
0.215\end{array}$ & $\begin{array}{l}-- \\
--\end{array}$ \\
\hline $\begin{array}{lll}\text { MAY } & 07-J U N & 02^{1} \\
\text { JUN } & 02 \text {-JUL } & 01\end{array}$ & $\begin{array}{l}79 \\
22\end{array}$ & $\begin{array}{l}4.9 \\
6.1\end{array}$ & $\begin{array}{l}23 \\
2.2\end{array}$ & 0.140 & $\begin{array}{l}24 \\
0.76\end{array}$ & $\begin{array}{l}1.00 \\
0.450\end{array}$ & $\begin{array}{l}0.490 \\
0.120\end{array}$ & $\begin{array}{l}3.40 \\
0.039\end{array}$ & $\begin{array}{l}-- \\
--\end{array}$ \\
\hline $\begin{array}{lll}\text { JUL } & 01 \text {-AUG } & 05^{1} \\
\text { AUG } & 05-S E P & 02\end{array}$ & $\begin{array}{l}45 \\
23\end{array}$ & $\begin{array}{l}5.1 \\
6.0\end{array}$ & $\begin{array}{l}9.8 \\
2.0\end{array}$ & $\begin{array}{l}0.180 \\
0.240\end{array}$ & $\begin{array}{l}11 \\
1.4\end{array}$ & $\begin{array}{l}0.510 \\
0.350\end{array}$ & $\begin{array}{l}1.45 \\
0.250\end{array}$ & $\begin{array}{l}0.258 \\
0.077\end{array}$ & $\begin{array}{l}-- \\
--\end{array}$ \\
\hline $\begin{array}{lll}\text { SEP } & 01-O C T & 01 \\
\text { OCT } & 01-N O V & 03 \\
\text { NOV } & 03-D E C & 02\end{array}$ & $\begin{array}{l}99 \\
11 \\
28\end{array}$ & $\begin{array}{l}7.0 \\
5.8 \\
4.6\end{array}$ & $\begin{array}{l}5.3 \\
2.2 \\
4.7\end{array}$ & $\begin{array}{l}3.49 \\
0.180 \\
0.310\end{array}$ & $\begin{array}{l}17 \\
0.38 \\
0.31\end{array}$ & $\begin{array}{l}0.680 \\
0.330 \\
0.690\end{array}$ & $\begin{array}{l}2.05 \\
0.040 \\
0.030\end{array}$ & $\begin{array}{l}1.85 \\
0.013 \\
0.013\end{array}$ & $\begin{array}{l}2.2 \\
0.76 \\
0.56\end{array}$ \\
\hline DEC 02 1993- & & & & & & & & & \\
\hline JAN $12 \quad 1994$ & 65 & 4.4 & 6.6 & 0.530 & 0.53 & 1.20 & 0.030 & 0.022 & 0 \\
\hline JAN $12-31$ & 57 & 4.3 & 4.6 & 0.680 & 0.64 & 1.40 & 0.020 & 0.012 & 0.41 \\
\hline JAN 31-MAR 01 & 80 & 4.0 & 6.9 & 0.480 & 0.65 & 1.80 & 0.035 & 0.017 & 1.3 \\
\hline MAR 01-APR 01 & 63 & 4.0 & 8.7 & 0.620 & 0.59 & 1.40 & 0.025 & 0.014 & 1.4 \\
\hline APR $01-M A Y \quad 02$ & 10 & 6.1 & 1.5 & 0.120 & 0.30 & 0.370 & 0.035 & 0.008 & 0.87 \\
\hline MAY 02 -JUN 01 & 87 & 4.0 & 11 & 2.10 & 3.9 & 1.60 & 0.353 & 0.084 & 2.9 \\
\hline JUN $01-30$ & 39 & 5.4 & 3.6 & 0.330 & 1.7 & 1.00 & 0.460 & 0.255 & 0.66 \\
\hline JUN 30-JUL 29 & 20 & 5.8 & 3.6 & 0.190 & 0.84 & 0.450 & 0.290 & 0.210 & 1.4 \\
\hline JUL 29-AUG 31 & 72 & 3.9 & 9.8 & 1.50 & 2.5 & 1.00 & 0.450 & 0.305 & 1.9 \\
\hline AUG 31-OCT 03 & 41 & 4.8 & 5.1 & 0.790 & 1.4 & 1.00 & 0.140 & 0.038 & 2.0 \\
\hline
\end{tabular}

\begin{tabular}{|c|c|c|c|c|c|c|c|c|}
\hline DATE & $\begin{array}{l}\text { CALCIUM, } \\
\text { TOTAL } \\
\text { RECOV- } \\
\text { ERABLE } \\
(\mathrm{mg} / \mathrm{L} \\
\text { AS Ca) }\end{array}$ & $\begin{array}{l}\text { MAGNE- } \\
\text { SIUM, } \\
\text { DIS- } \\
\text { SOLVED } \\
\text { (mg/L } \\
\text { AS Mg) }\end{array}$ & $\begin{array}{l}\text { SODIUM, } \\
\text { DIS- } \\
\text { SOLVED } \\
(\mathrm{mg} / \mathrm{L} \\
\text { AS Na) } \\
\end{array}$ & $\begin{array}{l}\text { POTAS- } \\
\text { SIUM, } \\
\text { DIS- } \\
\text { SOLVED } \\
(\mathrm{mg} / \mathrm{L} \\
\text { AS K) }\end{array}$ & $\begin{array}{l}\text { CHLO- } \\
\text { RIDE, } \\
\text { DIS- } \\
\text { SOLVED } \\
(\mathrm{mg} / \mathrm{L} \\
\mathrm{AS} \mathrm{CI)}\end{array}$ & $\begin{array}{l}\text { SULFATE, } \\
\text { DIS- } \\
\text { SOLVED } \\
(\mathrm{mg} / \mathrm{L} \\
\left.\text { AS SO } \mathrm{SO}_{4}\right)\end{array}$ & $\begin{array}{l}\text { LEAD, } \\
\text { TOTAL } \\
\text { RECOV- } \\
\text { ERABLE } \\
(\mu \mathrm{g} / \mathrm{L} \\
\mathrm{AS} \mathrm{Pb}) \\
\end{array}$ & $\begin{array}{l}\text { ZINC, } \\
\text { POTAL } \\
\text { RECOV- } \\
\text { ERABLE } \\
(\mu \mathrm{g} / \mathrm{L} \\
\text { AS Zn) }\end{array}$ \\
\hline NOV 05- & 0.20 & 0.04 & $<0 \quad 10$ & 0.10 & 0.20 & 20 & $<5$ & 20 \\
\hline DEC 02 1992- & & & & & & & & \\
\hline JAN 051993 & 0.46 & 0.14 & 0.85 & 0.07 & 1.3 & 5.0 & 10 & $<40$ \\
\hline APR 14-MAY 07 & 2.3 & 0.56 & 0.21 & 0.18 & 0.52 & 8.0 & 8 & 50 \\
\hline MAY 07 -JUN $02^{1}$ & 3.0 & 0.81 & 1.9 & 20 & 9.2 & -- & 10 & $<40$ \\
\hline JUN 02-JUL 01 & 1.8 & 0.48 & 0.26 & 0.30 & 0.30 & -- & 6 & 100 \\
\hline JUL 01 -AUG $05^{1}$ & 3.3 & 0.76 & 0.76 & 0.22 & 2.8 & 10 & 6 & 90 \\
\hline AUG $05-S E P \quad 02$ & 1.4 & 0.44 & 0.12 & 0.44 & 0.92 & 6.0 & $<5$ & $<40$ \\
\hline SEP $\quad 01$-OCT $01^{1}$ & -- & 0.68 & 0.86 & 2.4 & 2.1 & 11 & 11 & 50 \\
\hline OCT 01 -NOV 03 & -- & 0.21 & $<0.02$ & $<0.02$ & 0.20 & 2.0 & 9 & $<40$ \\
\hline NOV $03-D E C \quad 02$ & -- & 0.24 & 0.46 & $<0.05$ & 0.94 & 3.6 & 5 & 40 \\
\hline DEC $021993-$ & & & & & & & & \\
\hline JAN $12 \quad 1994$ & -- & 0.20 & 2.0 & 0.03 & 4.8 & 4.0 & 13 & $<40$ \\
\hline JAN $12-31$ & -- & 0.13 & 2.0 & 0.03 & 3.1 & 4.0 & 8 & 40 \\
\hline JAN 31-MAR 01 & -- & 0.41 & 6.0 & 0.06 & 8.0 & 6.0 & 12 & 40 \\
\hline MAR $01-A P R \quad 01$ & -- & 0.46 & -- & 0.04 & 1.5 & 8.0 & 9 & 40 \\
\hline APR $01-M A Y \quad 02$ & -- & 0.14 & 0.09 & 0.03 & 0.30 & $<2.0$ & $<5$ & 40 \\
\hline MAY $02-J U N ~ 01$ & -- & 0.90 & $<0.20$ & - & 0.80 & 18 & 19 & 40 \\
\hline JUN $01-30$ & -- & 0.73 & 1.1 & 1.1 & 1.9 & 8.1 & 7 & 60 \\
\hline JUN 30-JUL 29 & -- & 0.29 & 0.10 & 0.64 & 0.50 & 3.4 & 7 & 60 \\
\hline JUL 29-AUG 31 & -- & 0.66 & 0.25 & 0.80 & 0.50 & 14 & 6 & 40 \\
\hline AUG 31-OCT 03 & -- & 0.69 & 0.30 & 0.24 & 0.80 & 8.1 & 11 & $<40$ \\
\hline
\end{tabular}

${ }^{1}$ Results affected by contamination; bird droppings, insects, and water noted in bucket. 
Table A-3. Analyses of atmospheric deposition in northern part of Ellison Park wetland, Monroe County, N.Y., April 1992 through September 1994 (station 431021077315902)--continued

[Sampling location is shown in fig. $2 . \mu \mathrm{S} / \mathrm{cm}$, microsiemens per centimeter; $\mathrm{mg} / \mathrm{L}$, milligrams per liter; $\mu \mathrm{g} / \mathrm{L}$, micrograms per liter; <, less than; --, no data.]

Part C. Bulk sample analyses ${ }^{1}$

\begin{tabular}{|c|c|c|c|c|c|c|c|c|c|}
\hline & DATE & $\begin{array}{l}\text { SPE- } \\
\text { CIFIC } \\
\text { CON- } \\
\text { DUCT- } \\
\text { ANCE } \\
(\mu \mathrm{S} / \mathrm{cm})\end{array}$ & $\begin{array}{c}\mathrm{pH} \\
\text { WATER } \\
\text { WHOLE } \\
\text { LAB } \\
\text { (STAND- } \\
\text { ARD } \\
\text { UNITS) }\end{array}$ & $\begin{array}{c}\text { ACIDITY } \\
(\mathrm{mg} / \mathrm{L} \\
\mathrm{AS} \\
\left.\mathrm{CACO}_{3}\right)\end{array}$ & $\begin{array}{c}\text { NITRO- } \\
\text { GEN, } \\
\text { AMMONIA } \\
\text { DIS- } \\
\text { SOLVED } \\
\text { (mg / L } \\
\text { AS N) }\end{array}$ & $\begin{array}{l}\text { NITRO- } \\
\text { GEN, AM- } \\
\text { MONIA + } \\
\text { ORGANIC } \\
\text { TOTAL } \\
\text { (mg/L } \\
\text { AS N) }\end{array}$ & $\begin{array}{c}\text { NITRO- } \\
\text { GEN, } \\
\text { NO2 +NO3 } \\
\text { TOTAL } \\
(\mathrm{mg} / \mathrm{L} \\
\text { AS N) }\end{array}$ & $\begin{array}{c}\text { PHOS- } \\
\text { PHORUS } \\
\text { TOTAL } \\
\text { (mg / L } \\
\text { AS P) }\end{array}$ & $\begin{array}{c}\text { PHOS- } \\
\text { PHORUS } \\
\text { ORTHO } \\
\text { DIS- } \\
\text { SOLVED } \\
\text { (mg/L } \\
\text { AS P) }\end{array}$ \\
\hline \multicolumn{10}{|c|}{ APR $10-$} \\
\hline MAY & Y O5 1992 & 68 & 4.1 & 8.7 & 0.960 & 1.2 & 1.20 & 0.028 & 0.005 \\
\hline APR & 10-MAY 05 & 69 & 4.1 & 8.0 & 1.00 & 1.1 & 1.30 & 0.030 & 0.005 \\
\hline MAY & 05-JUN 04 & 91 & 4.0 & 12 & 1.60 & 3.4 & 1.30 & 0.280 & 0.076 \\
\hline MAY & 05-JUN 04 & 90 & 3.9 & 12 & 1.50 & 3.6 & 1.30 & 0.390 & 0.150 \\
\hline JUN C & 04-JUL $06^{2}$ & 203 & 7.5 & 4.6 & 2.30 & 6.5 & 1.60 & 0.960 & 0.064 \\
\hline JUN & 04 -JUL $06^{2}$ & 322 & 7.3 & 14 & 11.0 & 44 & 3.40 & 5.60 & 5.10 \\
\hline JUL & $06-27$ & 42 & 4.3 & 6.4 & 0.370 & 0.50 & 0.470 & 0.030 & 0.008 \\
\hline JUL & $06-27$ & 41 & 4.2 & 6.3 & 0.370 & 0.45 & 0.460 & 0.035 & 0.011 \\
\hline JUL 2 & $28-\operatorname{SEP} 01$ & 66 & 4.0 & 9.2 & 0.160 & 0.56 & 0.710 & 0.045 & 0.002 \\
\hline JUL 2 & 28-SEP 01 & 73 & 3.9 & 9.5 & 0.480 & 0.76 & 0.760 & 0.050 & 0.007 \\
\hline SEP & 01-OCT 01 & 29 & 6.2 & 2.6 & 1.40 & 2.6 & 0.530 & 0.280 & 0.220 \\
\hline SEP & 01-OCT 01 & 57 & 7.0 & 4.4 & 3.00 & 5.9 & 0.560 & 0.870 & 0.815 \\
\hline
\end{tabular}

\begin{tabular}{|c|c|c|c|c|c|c|c|c|c|}
\hline & \multirow[t]{2}{*}{ DATE } & \multirow[t]{2}{*}{$\begin{array}{l}\text { CALCIUM, } \\
\text { TOTAL } \\
\text { RECOV- } \\
\text { ERABLE } \\
\text { (mg/L } \\
\text { AS Ca) }\end{array}$} & $\begin{array}{l}\text { MAGNE- } \\
\text { SIUM, } \\
\text { DIS- } \\
\text { SOLVED } \\
\text { (mg/L }\end{array}$ & $\begin{array}{l}\text { SODIUM, } \\
\text { DIS- } \\
\text { SOLVED } \\
\text { (mg/L }\end{array}$ & \multirow[t]{2}{*}{$\begin{array}{l}\text { POTAS- } \\
\text { SIUM, } \\
\text { DIS- } \\
\text { SOLVED } \\
(\mathrm{Mg} / \mathrm{L} \\
\text { AS K) }\end{array}$} & \multirow[t]{2}{*}{$\begin{array}{l}\text { CHLO- } \\
\text { RIDE, } \\
\text { DIS- } \\
\text { SOLVED } \\
\text { (mg/L } \\
\text { AS Cl) }\end{array}$} & $\begin{array}{l}\text { SULFATE, } \\
\text { DIS- } \\
\text { SOLVED } \\
\text { (mg/L }\end{array}$ & $\begin{array}{l}\text { LEAD, } \\
\text { TOTAL } \\
\text { RECOV- } \\
\text { ERABLE } \\
(\mu \mathrm{g} / \mathrm{L}\end{array}$ & \multirow[t]{2}{*}{$\begin{array}{l}\text { ZINC, } \\
\text { TOTAL } \\
\text { RECOV- } \\
\text { ERABLE } \\
(\mu \mathrm{g} / \mathrm{L} \\
\text { AS Zn) }\end{array}$} \\
\hline & & & AS Mg) & AS $\mathrm{Na}$ ) & & & $\left.\mathrm{AS} \quad \mathrm{SO}_{4}\right)$ & $A S \quad \mathrm{~Pb})$ & \\
\hline \multicolumn{10}{|c|}{ APR $10-$} \\
\hline & $A Y \quad 05 \quad 1992$ & 0.80 & 0.18 & 0.07 & 0.06 & 0.20 & 8.0 & 7 & 20 \\
\hline APR & 10-MAY 05 & 0.77 & 0.16 & 0.06 & 0.06 & 0.20 & 8.0 & 5 & 40 \\
\hline MAY & 05 -JUN 04 & 2.1 & 1.2 & 0.26 & 0.49 & 0.60 & 14 & 10 & 50 \\
\hline MAY & 05 -JUN 04 & 2.1 & 1.1 & 0.24 & 0.51 & 1.2 & 15 & 13 & 30 \\
\hline JUN & 04 -JUL $06^{2}$ & 18 & 1.6 & 1.6 & 0.31 & 2.4 & 34 & 59 & 260 \\
\hline JUN & 04 -JUL $06^{2}$ & 7.7 & 2.0 & 3.3 & 0.15 & 4.9 & 52 & 23 & 140 \\
\hline JUL & $06-27$ & 0.36 & 0.10 & 0.05 & 0.05 & 0.60 & 10 & 6 & $<40$ \\
\hline JUL & $06-27$ & 0.31 & 0.09 & 0.04 & 0.03 & 0.20 & 10 & $<5$ & $<40$ \\
\hline JUL & 28-SEP 01 & 0.60 & 0.64 & 0.09 & 0.09 & 0.60 & 10 & 9 & $<40$ \\
\hline JUL & 28 -SEP 01 & 0.14 & 0.15 & 0.06 & 0.06 & 0.30 & $<10$ & 6 & $<40$ \\
\hline SEP & 01-OCT 01 & 1.1 & 0.29 & 0.20 & 0.87 & 1.1 & 6.0 & $<5$ & $<40$ \\
\hline SEP & $01-\mathrm{OCT} 01$ & 2.0 & 0.33 & 0.47 & -- & 1.6 & 7.0 & 8 & $<40$ \\
\hline
\end{tabular}

1 Analytical results for the "wet" and "dry" samples are presented as bulk-sample analyses because both buckets of the atmospheric-deposition collector were exposed to both "wet" and "dry" atmospheric conditions.

2 Results affected by contamination; bird feathers and mud noted in bucket. 
Table A-4. Analyses of sediment samples collected in the Ellison Park wetland, Monroe County, N.Y., October 1994

[Sampling locations are shown in fig. 7. $\mu \mathrm{g} / \mathrm{g}$, microgram per gram; BOT MAT or BM, bottom material; <63U WS, material passing through a 63 -micron wet seive; DW REC, dry weight recoverable; $<$, less than.]

Part A. Major Elements, Trace Elements, and Carbon

\begin{tabular}{|c|c|c|c|c|c|c|c|c|c|}
\hline \multirow[b]{4}{*}{ STATION NUMBER } & \multirow{4}{*}{$\begin{array}{l}\text { LOCAL } \\
\text { SITE } \\
\text { ID }\end{array}$} & $\begin{array}{l}\text { ALUM- } \\
\text { INUM }\end{array}$ & $\begin{array}{l}\text { ANTI - } \\
\text { MONY }\end{array}$ & ARSENIC & BARIUM & \multicolumn{2}{|l|}{ BERYL - } & CADMIUM & CALCIUM \\
\hline & & BOT MAT & BOT MAT & BOT MAT & BOT MAT & BOT MAT & BOT MAT & BOT MAT & BOT MAT \\
\hline & & $<63 U$ WS & $<63 \mathrm{U}$ WS & $<63 \mathrm{U}$ WS & $<63 U$ WS & $<63 \mathrm{U}$ WS & $<180$ UWS & $<63 \mathrm{U}$ WS & $<63 \mathrm{U}$ WS \\
\hline & & $\begin{array}{l}\text { FIELD } \\
\text { PERCENT }\end{array}$ & $\begin{array}{l}\text { FIELD } \\
(\mu \mathrm{g} / \mathrm{g})\end{array}$ & $\begin{array}{l}\text { FIELD } \\
(\mu \mathrm{g} / \mathrm{g})\end{array}$ & $\begin{array}{l}F I E L D \\
(\mu \mathrm{g} / \mathrm{g})\end{array}$ & $\begin{array}{l}\text { FIELD } \\
(\mu \mathrm{g} / \mathrm{g})\end{array}$ & $\begin{array}{l}\text { FIELD } \\
(\mu g / g)\end{array}$ & $\begin{array}{l}\text { FIELD } \\
(\mu \mathrm{g} / \mathrm{g})\end{array}$ & $\begin{array}{l}\text { FIELD } \\
\text { PERCENT }\end{array}$ \\
\hline 430951077312801 & SQ1 & 5.0 & 0.4 & 4.9 & 460 & 1 & $<10$ & 0.9 & 6.4 \\
\hline & & 5.0 & .5 & 5.1 & 460 & 1 & $<10$ & .7 & 6.6 \\
\hline 430952077314001 & $\mathrm{SQ} 2$ & 4.9 & .2 & 5.0 & 450 & 1 & $<10$ & .9 & 6.7 \\
\hline 431021077315901 & SQ3 & 4.8 & .6 & 3.9 & 470 & 1 & $<10$ & 3.8 & 4.7 \\
\hline
\end{tabular}

\begin{tabular}{|c|c|c|c|c|c|c|c|c|c|c|}
\hline & CERIUM & $\begin{array}{l}\text { CHRO- } \\
\text { MIUM }\end{array}$ & COBALT & COPPER & $\begin{array}{l}\text { EURO- } \\
\text { PIUM }\end{array}$ & GALLIUM & GOLD & HOLMIUM & IRON & $\begin{array}{c}\text { LANTHA- } \\
\text { NUM }\end{array}$ \\
\hline LOCAL & BOT MAT & BOT MAT & BOT MAT & BOT MAT & BOT MAT & BOT MAT & BOT MAT & BOT MAT & BOT MAT & BOT MAT \\
\hline SITE & $<63 \mathrm{U}$ WS & $<63 \mathrm{U}$ WS & $<63 \mathrm{U}$ WS & $<63 \mathrm{U}$ WS & $<63 U$ WS & $<63 \mathrm{U}$ WS & $<63 \mathrm{U}$ WS & $<63 U$ WS & $<63$ U WS & $<630$ WS \\
\hline ID & $\begin{array}{l}\text { FIELD } \\
(\mu \mathrm{g} / \mathrm{g})\end{array}$ & $\begin{array}{l}\text { FIELD } \\
(\mu \mathrm{g} / \mathrm{g})\end{array}$ & $\begin{array}{l}\text { FIELD } \\
(\mu \mathrm{g} / \mathrm{g})\end{array}$ & $\begin{array}{l}\text { FIELD } \\
(\mu \mathrm{g} / \mathrm{g})\end{array}$ & $\begin{array}{l}\text { FIELD } \\
(\mu \mathrm{g} / \mathrm{g})\end{array}$ & $\begin{array}{l}\text { FIELD } \\
(\mu g / g)\end{array}$ & $\begin{array}{l}\text { FIELD } \\
(\mu \mathrm{g} / \mathrm{g})\end{array}$ & $\begin{array}{l}\text { FIELD } \\
(\mu \mathrm{g} / \mathrm{g})\end{array}$ & $\begin{array}{l}\text { FIELD } \\
\text { PERCENT }\end{array}$ & $\begin{array}{l}\text { FIELD } \\
(\mu \mathrm{g} / \mathrm{g})\end{array}$ \\
\hline
\end{tabular}

$\begin{array}{lll}\text { SQ1 } & 45 & 43 \\ & 44 & 43 \\ \text { SQ2 } & 45 & 46 \\ \text { SQ3 } & 39 & 59\end{array}$

$\begin{array}{lll}43 & 11 & 41 \\ 43 & 10 & 38 \\ 46 & 12 & 49 \\ 59 & 10 & 72\end{array}$

$\begin{array}{lll}41 & <2 & 11 \\ 38 & <2 & 12 \\ 49 & <2 & 12 \\ 72 & <2 & 11\end{array}$

$\begin{array}{ll}<8 & <4 \\ <8 & <4 \\ <8 & <4\end{array}$

$\begin{array}{lll}<4 & 2.7 & 25 \\ <4 & 2.7 & 25 \\ <4 & 2.8 & 25 \\ <4 & 2.4 & 23\end{array}$

$\begin{array}{lll} & & \\ \text { LOCAL } & \text { LEAD } & \text { LITHIUM } \\ \text { SITE } & <63 \text { MAT } & \text { BOT MAT } \\ \text { ID } & \text { FIELD } & \text { FIELD WS } \\ & (\mu \mathrm{g} / \mathrm{g}) & (\mu \mathrm{g} / \mathrm{g})\end{array}$

$\begin{array}{ll}\text { MAGNE- } & \text { MANGA- } \\ \text { SIUM } & \text { NESE } \\ \text { BOT MAT } & \text { BOT MAT } \\ <63 U \text { WS } & <63 \text { U WS } \\ \text { FIELD } & \text { FIELD } \\ \text { PERCENT } & (\mu \mathrm{g} / \mathrm{g})\end{array}$

\begin{tabular}{lll} 
& \multicolumn{1}{c}{ MOLYB- } & NEODYM- \\
MERCURY & DENUM & \multicolumn{1}{c}{ IUM } \\
BOT MAT & BOT MAT & BOT MAT \\
$<63 U$ WS & $<63 U$ WS & $<63 U$ WS \\
FIELD & FIELD & FIELD \\
$(\mu \mathrm{g} / \mathrm{g})$ & $(\mu \mathrm{g} / \mathrm{g})$ & $(\mu \mathrm{g} / \mathrm{g})$
\end{tabular}

$\begin{array}{ll} & \\ \text { BICKEL } & \text { NIOBIUM } \\ \text { BOT MAT }\end{array}$

PHOSAT BOT MAT $<63 \mathrm{U}$ WS $<63 \mathrm{U}$ WS $<63 \mathrm{U}$ WS $(\mu \mathrm{g} / \mathrm{g}) \quad(\mu \mathrm{g} / \mathrm{g})$ ERCENT

880
890
720

0.11
.10
.14
.33

$<2$
$<2$
$<2$

25
26

26

1.2
1.3

530

.33

$<2$

23

$\mu g / g)$

FIELD

FIELD

SQ3

\begin{tabular}{lll} 
& POTAS- & \multicolumn{1}{c}{ SCAN- } \\
& SIUM & DIUM \\
LOCAL & BOT MAT & BOT MAT \\
SITE & $<63 U$ WS & $<63 U$ WS \\
ID & FIELD & FIELD \\
& PERCENT & $(\mu \mathrm{g} / \mathrm{g})$
\end{tabular}

SELE-
NIUM
BOT MAT
$<63 U$ WS
FIELD
$(\mu g / g)$

SILVER
BOT MAT
$<63 U$ WS
FIELD
$(\mu \mathrm{g} / \mathrm{g})$

$\begin{array}{cc} & \text { STRON- } \\ \text { SODIUM } & \text { TIUM } \\ \text { BOT MAT } & \text { BOT MAT } \\ \text { <63U WS } & <63 U \text { WS } \\ \text { FIELD } & \text { FIELD } \\ \text { PERCENT } & (\mu \mathrm{g} / \mathrm{g})\end{array}$

SULFUR
BOT MAT
$<63 U$ WS
FIELD
PERCENT

TANTA-

LUM THORIUM TIN BOT MAT BOT MAT BOT MAT $<63 U$ WS $<63 U$ WS $<63 U$ WS FIELD FIELD FIELD

SQ1

SQ2

$\mathrm{SQ} 3$

1.7
1.7
1.6
1.6

0.5
.6
.8
.8

$\begin{array}{rr}0.5 & 1.2 \\ .5 & 1.2 \\ .7 & 1.1 \\ 2.3 & 1.3\end{array}$

$\begin{array}{ll}420 & 0.34 \\ 420 & .33 \\ 440 & .60 \\ 340 & .35\end{array}$

$(\mu g / g)$

$$
(\mu \mathrm{g} / \mathrm{g}) \quad(\mu \mathrm{g} / \mathrm{g})
$$

$\begin{array}{lll}<40 & 4.7 & <10 \\ <40 & 7.8 & <10 \\ <40 & 6.5 & <10 \\ <40 & 5.7 & <10\end{array}$

\begin{tabular}{|c|c|c|c|c|c|c|c|c|c|}
\hline & $\begin{array}{l}\text { TITA- } \\
\text { NIUM, }\end{array}$ & URANIUM & $\begin{array}{l}\text { VANA- } \\
\text { DIUM }\end{array}$ & YTTRIUM & $\begin{array}{l}\text { YTTER- } \\
\text { BIUM }\end{array}$ & ZINC & $\begin{array}{l}\text { CARBON, } \\
\text { ORGANIC } \\
\text { BOT MAT }\end{array}$ & $\begin{array}{l}\text { CARBON, } \\
\text { ORG + } \\
\text { INORG, }\end{array}$ & $\begin{array}{l}\text { CARBON, } \\
\text { INORGANIC, } \\
\text { BOT MAT }\end{array}$ \\
\hline LOCAL & BOT MAT & BOT MAT & BOT MAT & BOT MAT & BOT MAT & BOT MAT & $<630$ WS & BOT MAT & $<63 \mathrm{U}$ WS \\
\hline SITE & $<63 \mathrm{U}$ WS & $<63 \mathrm{U}$ WS & $<63 \mathrm{U}$ WS & $<63 U$ WS & $<63 \mathrm{U}$ WS & $<63 \mathrm{U}$ WS & DW REC & $<63 \mathrm{U}$ WS & DW REC \\
\hline ID & $\begin{array}{c}\text { DW REC } \\
\text { (PERCENT) }\end{array}$ & $\begin{array}{l}\text { FIELD } \\
(\mu \mathrm{g} / \mathrm{g})\end{array}$ & $\begin{array}{l}\text { FIELD } \\
(\mu \mathrm{g} / \mathrm{g})\end{array}$ & $\begin{array}{l}\text { FIELD } \\
(\mu \mathrm{g} / \mathrm{g})\end{array}$ & $\begin{array}{l}\text { FIELD } \\
(\mu g / g)\end{array}$ & $\begin{array}{l}\text { FIELD } \\
(\mu g / g)\end{array}$ & $\begin{array}{l}\text { (PER- } \\
\text { CENT) }\end{array}$ & $\begin{array}{c}\text { DW } \\
\text { (PEC } \\
\text { (PERCENT) }\end{array}$ & $\begin{array}{l}\text { (PER- } \\
\text { CENT) }\end{array}$ \\
\hline SQ1 & 0.26 & 1.6 & 50 & 20 & 2 & 210 & 3.4 & 5.4 & 1.9 \\
\hline & 0.26 & 1.6 & 49 & 20 & 2 & 220 & 3.5 & 5.4 & 1.9 \\
\hline SQ2 & 0.25 & 1.6 & 50 & 19 & 2 & 230 & 5.0 & 6.9 & 1.9 \\
\hline SQ3 & 0.27 & 1.7 & 45 & 19 & 2 & 250 & 3.7 & 5.1 & 1.4 \\
\hline
\end{tabular}


Table A-4. Analyses of sediment samples collected in the Ellison Park wetland, Monroe County, N.Y., October 1994--continued

[Sampling locations are shown in fig. 7. $\mu \mathrm{g} / \mathrm{g}$, microgram per gram; BOT MAT or BM, bottom material; <63U WS, material passing through a 63 micron wet seive; DW REC, dry weight recoverable; <, less than.]

Part B. Polynuclear aromatic hydrocarbons

\begin{tabular}{|c|c|c|c|c|c|c|c|c|c|c|c|}
\hline STATION NUMBER & $\begin{array}{l}\text { LOCAL } \\
\text { SITE } \\
\text { ID }\end{array}$ & $\begin{array}{c}\text { PARA- } \\
\text { CHLORO- } \\
\text { META } \\
\text { CRESOL } \\
\text { BOT.MAT } \\
(\mu \mathrm{g} / \mathrm{kg})\end{array}$ & $\begin{array}{c}2- \\
\text { CHLORO- } \\
\text { PHENOL } \\
\text { BOT.MAT } \\
(\mu \mathrm{g} / \mathrm{kg})\end{array}$ & $\begin{array}{c}2,4-\mathrm{DI}- \\
\text { CHLORO- } \\
\text { PHENOL } \\
\text { BOT.MAT } \\
(\mu \mathrm{g} / \mathrm{kg})\end{array}$ & $\begin{array}{l}2,4-\mathrm{DP} \\
\mathrm{IN} \\
\mathrm{BOTTOM} \\
\mathrm{MAT} . \\
(\mu \mathrm{g} / \mathrm{kg})\end{array}$ & \begin{tabular}{l}
\multicolumn{1}{c}{$4,6-$} \\
DINITRO \\
-ORTHO- \\
CRESOL \\
BOT.MAT \\
$(\mu \mathrm{g} / \mathrm{kg})$
\end{tabular} & $\begin{array}{c}2,4- \\
\text { DI- } \\
\text { NITRO- } \\
\text { PHENOL } \\
\text { BOT.MAT } \\
(\mu \mathrm{g} / \mathrm{kg})\end{array}$ & $\begin{array}{c}2- \\
\text { NITRO- } \\
\text { PHENOL } \\
\text { BOT.MAT } \\
(\mu \mathrm{g} / \mathrm{kg})\end{array}$ & $\begin{array}{c}4- \\
\text { NITRO- } \\
\text { PHENOL } \\
\text { BOT.MAT } \\
(\mu \mathrm{g} / \mathrm{kg})\end{array}$ & $\begin{array}{r}\text { PENTA- } \\
\text { CHLORO- } \\
\text { PHENOL } \\
\text { BOT.MAT } \\
(\mu \mathrm{g} / \mathrm{kg})\end{array}$ & $\begin{array}{c}\text { PHENOL } \\
\left(\mathrm{C}_{6} \mathrm{H}_{5}\right. \\
-\mathrm{OH}) \\
\text { BOT.MAT } \\
(\mu \mathrm{g} / \mathrm{kg})\end{array}$ \\
\hline 430951077312801 & SQ1 & $\begin{array}{l}<600 \\
<600\end{array}$ & $\begin{array}{l}<200 \\
<200\end{array}$ & $\begin{array}{l}<200 \\
<200\end{array}$ & $\begin{array}{l}<200 \\
<200\end{array}$ & $\begin{array}{l}<600 \\
<600\end{array}$ & $\begin{array}{l}<600 \\
<600\end{array}$ & $\begin{array}{l}<200 \\
<200\end{array}$ & $\begin{array}{l}<600 \\
<600\end{array}$ & $\begin{array}{l}<600 \\
<600\end{array}$ & $\begin{array}{l}<200 \\
<200\end{array}$ \\
\hline $\begin{array}{l}430952077314001 \\
431021077315901\end{array}$ & $\begin{array}{l}\mathrm{SQ} 2 \\
\mathrm{SQ} 3\end{array}$ & $\begin{array}{l}<600 \\
<600\end{array}$ & $\begin{array}{l}<200 \\
<200\end{array}$ & $\begin{array}{l}<200 \\
<200\end{array}$ & $\begin{array}{l}<200 \\
<200\end{array}$ & $\begin{array}{l}<600 \\
<600\end{array}$ & $\begin{array}{l}<600 \\
<600\end{array}$ & $\begin{array}{l}<200 \\
<200\end{array}$ & $\begin{array}{l}<600 \\
<600\end{array}$ & $\begin{array}{l}<600 \\
<600\end{array}$ & $\begin{array}{l}<200 \\
<200\end{array}$ \\
\hline
\end{tabular}

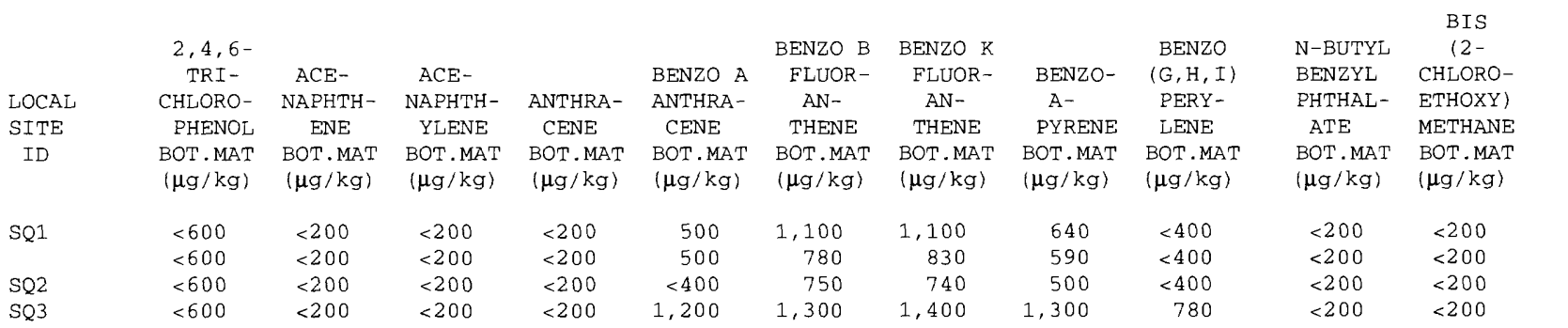

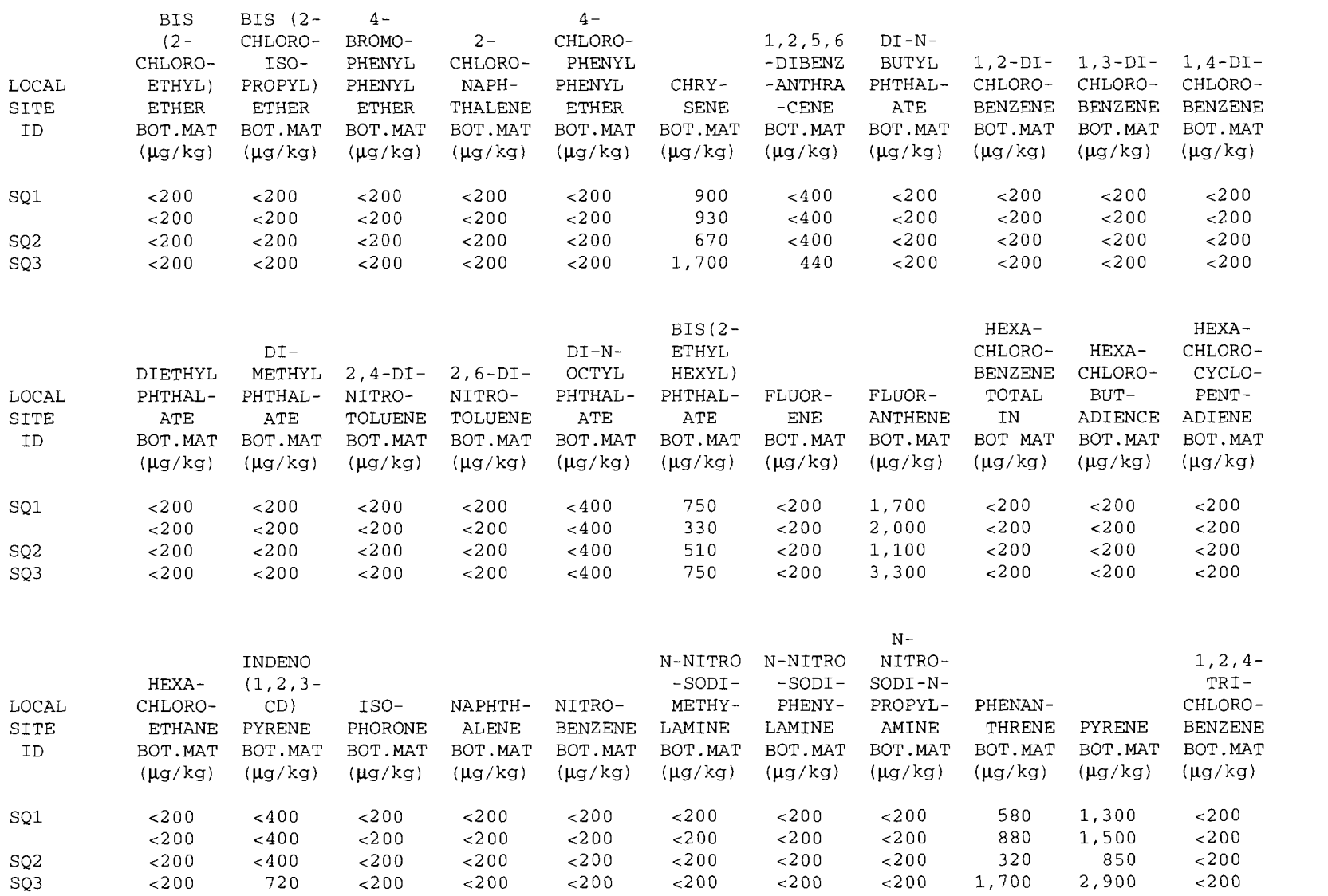


